\title{
MAXIMIZING FINANCE FOR DEVELOPMENT (MFD) IN AGRICULTURE AND FOOD SYSTEMS IN ETHIOPIA
} AN ANALYSIS OF BEEF, COFFEE, AND MAIZE 


\section{Acknowledgements}

The Ethiopia Maximizing Finance for Development Report was prepared by the team of Vikas Choudhary (TTL), Beza Hailu Woldergioris (Co-TTL), Duncan Pringle (Lead author), Dr. Girma Abebe, Rutta Firdissa, and Deriba Mekonnen. The peer reviewers were Christopher Brett, Harideep Singh, Diego Arias Carballo, and Maria Paulina Mogollon. Administrative support was provided by Adiam Berhane and Emebet Mekonnen Tesseme.

Additional inputs and guidance from Mark Cackler, Richard Spencer, and Holger Kray are gratefully appreciated. The team is also appreciative of the assistance provided by Mahlet Mekurie of ATA for sector information on beef and maize and thanks the many value chain actors in both the public and private sectors for their inputs and insights. 


\section{Table of Contents}

EXECUTIVE SUMMARY .1

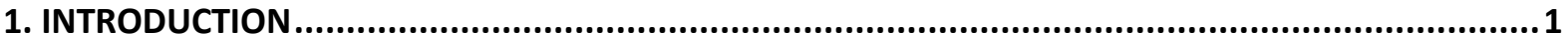

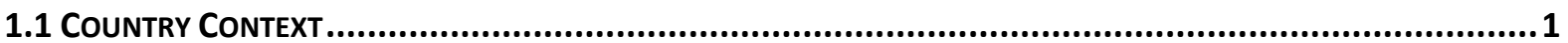

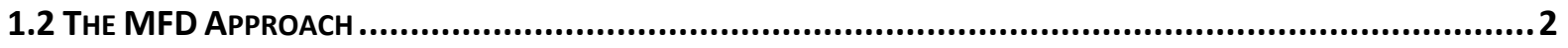

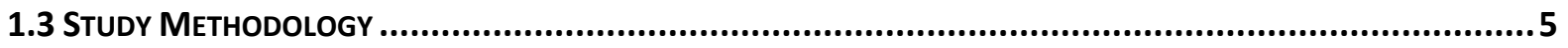

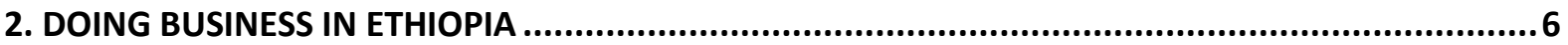

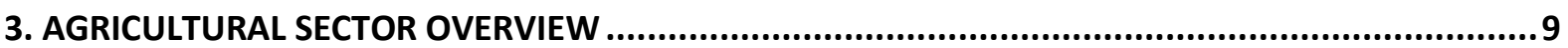

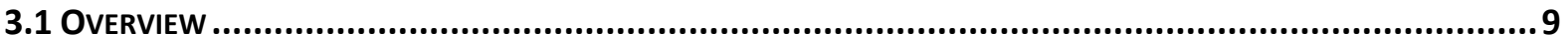

4. BEEF VALUE CHAIN OVERVIEW AND MFD DIAGNOSTICS .................................11

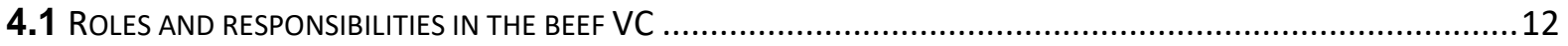

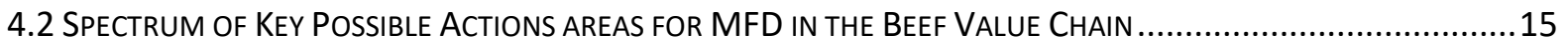

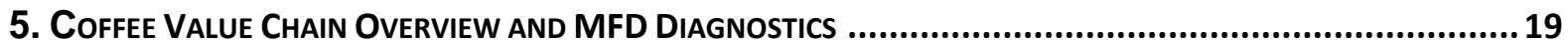

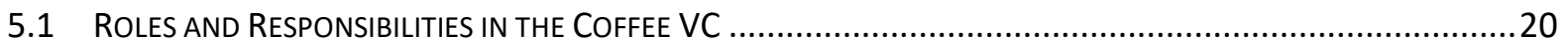

5.2 SPectrum of Key Possible Actions areas for MFD in the Coffee Value Chain ...............................23

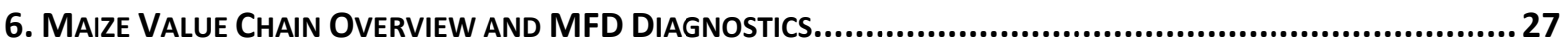

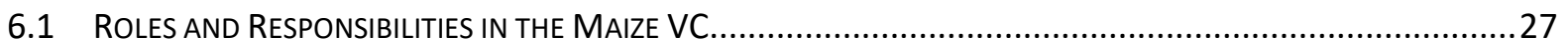

6.2 SPECtRum of Key Possible Actions aREas for MFD in the BeEF Value Chain ..........30

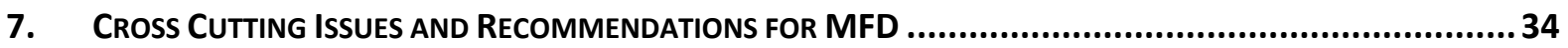

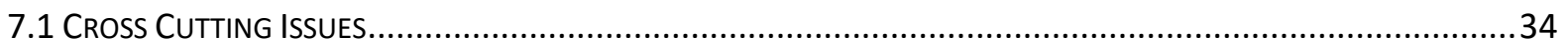

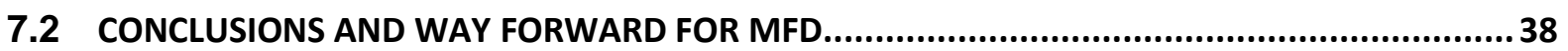

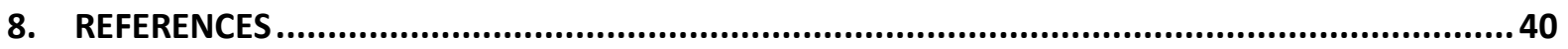

9. ANNEX

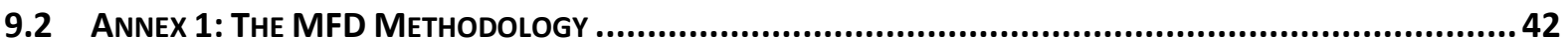

9.2 .1 BACKGROUND

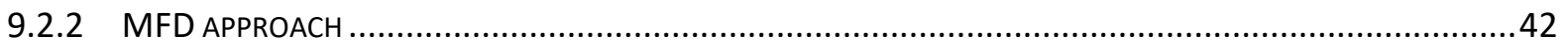

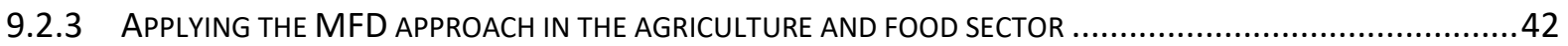

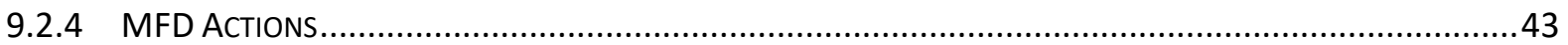

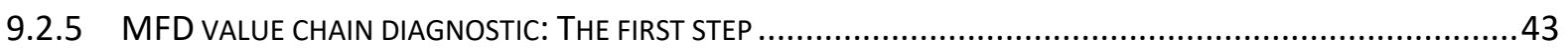

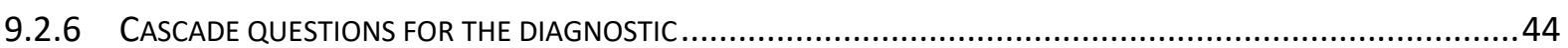

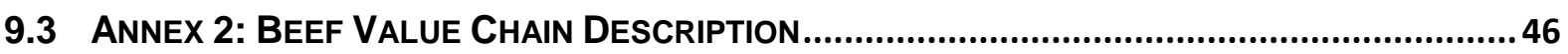

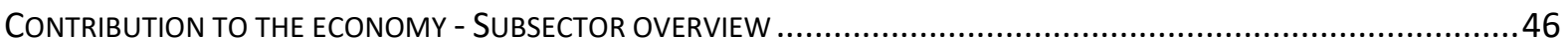

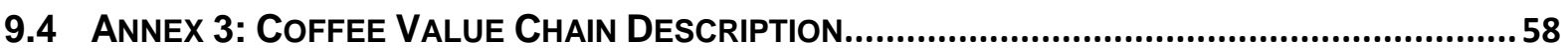

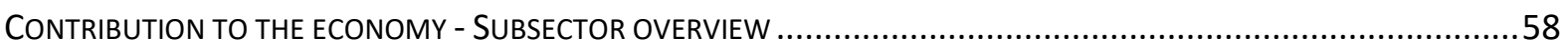

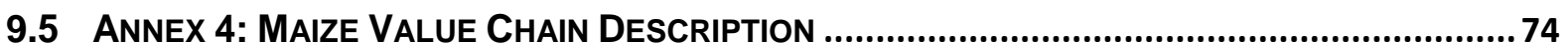

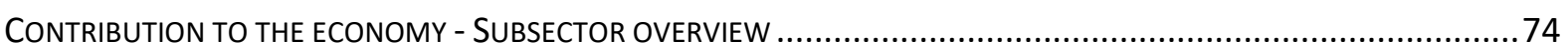




\section{Acronyms}

ACC Agricultural Commercialization Cluster

ATA Agricultural Transformation Agency

CAADP Comprehensive Africa Agriculture Development Program

CBE Commercial Bank of Ethiopia

CECSIR Comprehensive Ethiopian Coffee Strategy and Implementation Roadmap

CGA Citrus Growers Association of Southern Africa

CIG Common interest groups

CLU Coffee Liquoring Unit

COOP Cooperative

CPSD Country Private Sector Diagnostic

DA Development Agent

DBE Development Bank of Ethiopia

DCA Development Credit Authority

DFI Development Finance Institution

EBA Enabling the Business of Agriculture

ECEA Ethiopian Coffee Exporters Association

ECRA Ethiopian Coffee Roasters Association

ECTA Ethiopian Coffee and Tea Authority

ECX Ethiopian Commodity Exchange

EDFRA Ethiopian Veterinary Drug and Feed Regulatory Authority

EGTE Ethiopian Grain Trade Enterprise

EIAR Ethiopian Institute of Agricultural Research

EMDIDI Ethiopian Meat and Dairy Industry Development Institute

EO Extension Officer

ERCA Ethiopian Revenue and Customs Authority

ESE Ethiopian Seed Enterprise

ETB Ethiopian Birr, approximately ETB $28.5=$ USD 1

EU European Union

FDI Foreign Direct Investment

FMD Foot and Mouth Disease

FGoE Federal Government of Ethiopia

FSoE $\quad$ Federal State-owned Entity

FSol Federal State-owned Institute

FTC Farmer Training Center 


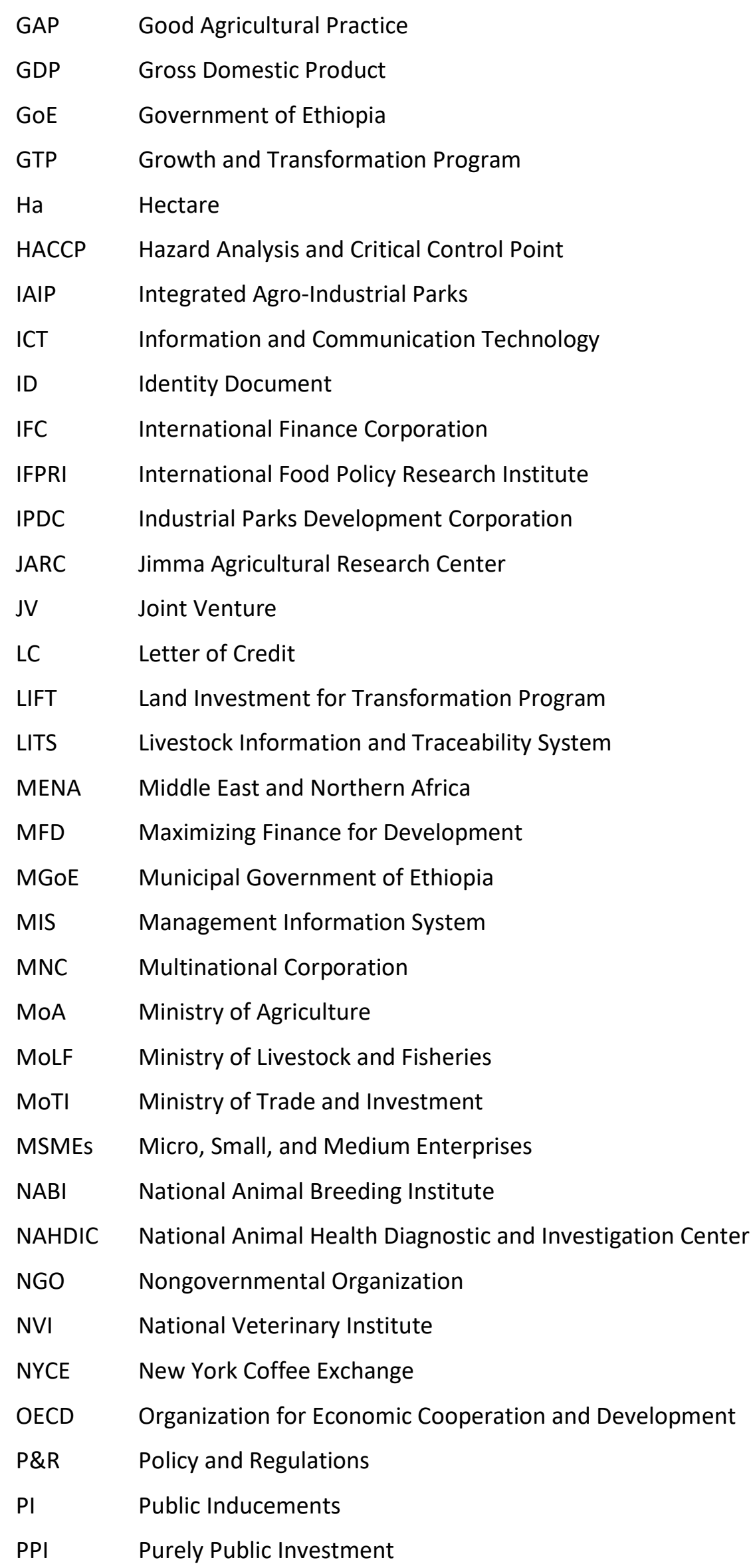




$\begin{array}{ll}\text { PPP } & \text { Public-Private Partnership } \\ \text { PS } & \text { Private Sector } \\ \text { PSE } & \text { Public Seed Enterprises } \\ \text { QC } & \text { Quality Control } \\ \text { RAI } & \text { Responsible Agricultural Investment } \\ \text { RARI } & \text { Regional Agricultural Research Institute } \\ \text { RBoA } & \text { Regional Bureaus of Agriculture } \\ \text { RGoE } & \text { Regional Government of Ethiopia } \\ \text { RSE } & \text { Regional Seed Enterprise } \\ \text { RSoE } & \text { Regional State-owned Enterprise } \\ \text { RVF } & \text { Rift Valley Fever } \\ \text { SACCO } & \text { Savings and Credit Cooperative } \\ \text { SDG } & \text { Sustainable Development Goal } \\ \text { SLLC } & \text { Secondary Level Land Certificate } \\ \text { SMEs } & \text { Small and Medium Enterprises } \\ \text { SoE } & \text { State-owned Entity } \\ \text { TA } & \text { Technical Assistance } \\ \text { UNIDO } & \text { United Nations Industrial Development Organization } \\ \text { USAID } & \text { U.S. Agency for International Development } \\ \text { VAT } & \text { Value Added Tax } \\ \text { VC } & \text { Value Chain } \\ \text { WBG } & \text { World Bank Group } \\ \text { WFP } & \text { World Food Programme } \\ \text { WS } & \text { Washing Station } \\ & \end{array}$




\section{Executive Summary}

The agricultural sector, dominant in the Ethiopian economy, is a vital source of economic growth. Over the past decade, the agricultural sector, largely driven by sizable public investment, has been growing at 7 percent per year. This encompasses agricultural extension, rural roads, and small scale irrigation. Despite the impressive gains made in improving yields in Ethiopian agriculture over the past decade, there are significant challenges that are limiting the transformation of agriculture sector. The sector is still predominantly subsistence-level for meeting household need (79 percent of maize is consumed by farming households) rather than commercialization for market consumption. The usage of technology is still limited, and only 13 percent of the total cereal cropped area is covered by improved seed. While the figure for pulses and oil seeds was $0.9 \%$ and $1.8 \%$ of the total pulse and oil seed cropped area were under improved seed, respectively. Close to 50 percent of farmers does not have access to fertilizers. Ethiopia has one of the lowest levels of agricultural mechanization in Sub-Saharan Africa. Agricultural credit and other financial services for smallholder farmers is at a nascent stage.

Ethiopia is one of the few countries which have surpassed the Comprehensive Africa Agriculture Development Programme (CAADP) target of investment. According to CAADP, Ethiopia has $16.8 \%$ of public agriculture expenditure as the share of total public expenditure. In comparison, neighboring Kenya has $2.3 \%$. Though the state-led model played a significant role in achieving growth, in the current macroeconomic environment the affordability and financial sustainability of the investments required and existing debts are proving difficult to maintain in the state-driven model. The rapid expansion of public infrastructure investment is reaching its limit both in terms of external debt sustainability and the crowding out of the private sector in the credit and foreign exchange markets.

So far, public institutions and programs have been primarily responsible for provision of goods and services for agricultural sector. Through a set of instruments, restrictive policies and regulations, restricted access to land, finance, distribution channels and different incentives, public programs have crowded out private sector in many activities. Private sector could potentially delivery these goods and services at scale, much lower costs, and more efficiently than the public sector and contribute to much needed transformation in agricultural sector.

Despite the massive investment by the state, there is a significant financing gap in realizing the full potential of the Ethiopian agricultural sector. Crowding in private investment and optimizing the use of scarce public resources is much needed. Also required is the continued promotion of good governance, environmental, and social sustainability. Increasing private sector investment and associated financing will require identifying and understanding market failures which currently lead to sub-optimal private provision of goods and services needed to achieve key development goals. Prioritizing country level actions can be informed by private sector oriented diagnostics and through active and effective public-private dialogue to define an impactful reform and investment agenda.

To this end, the World Bank Group (WBG) has developed a new diagnostic approach called Maximizing Finance for Development (MFD). This study pilots the use of the World Bank's MFD approach to identify areas along value chains (VCs) where the private sector is involved. More important may be the identification of where the private sector is currently not involved or only involved peripherially. The results provide a range of opportunities to consider, with the purpose of crowding in more private sector investment and sustainable solutions to achieve the Sustainable Development Goals (SDGs) and meet the highest environmental, social, and fiscal responsibility standards. Under each function, the underlying causes of market failure are assessed, helping inform a range of possible opportunities for private sector to participation. The ouputs of this report can be used for further stakeholder engagement to prioritize issues and assess solutions.

The Government of Ethiopia (GoE) and the World Bank Group (WBG) agreed to focus on the three VCs of beef, coffee, and maize. These three commodities accounts for over 50\% of Agricultural GDP and over $80 \%$ of foreign exchange revenue for the country and possess the potential for greater 
development impact through enhanced private sector activity. The nature of these three commodities differs in terms of commercialization. Coffee, a pure cash crop, has close to $95 \%$ of its product sold by the farmer. In contrast, maize is primarily a food crop and $89 \%$ of maize produced is consumed by farming households. Cattle, on the other hand, are sold by pastoralists when cash is needed, cattle are no longer serve a productive purpose or meeting social obligations. In highland areas, the commercialization aspect of cattle is much greater. This has implications for private sector engagement in the respective value chains.

This report identifies the issues and constraints in the three selected VCs and suggests opportunities for (a) the public sector to amend policy, regulations, and provide inducements for greater private sector activity, and (b) the private sector to take on a greater level of responsible agricultural investment (RAI) aligned with global good practice.

Beef value chain has ample opportunities to meet the rising domestic demand as well as the emerging export market. The diagnostics assessed 35 activities across the beef value chain. It highlighted that engagement of private sector toward the research and development and input markets is fairly limited. This provides an immediate opportunity in terms of manufacturing and delivery of vaccines and drugs; provision of artificial insemination, veterinary services; feed manufacturing and delivery; inspection and quality assurance services; quarantine facilities; commercial feedlot operations; as well as PPP in abattoir management and market infrastructure management. However, there are significant regulatory barriers to enable private sector participation in these activities. MFD diagnostics have identified a potential spectrum of actions that could help leverage private sector investment, improve performance of the beef value chain, and generate jobs.

Coffee enjoys a considerable investment by the private sector in roasting, blending, processing, and export facilities in Ethiopia. There are opportunities to further increase investments by expanding existing operations, as well as entering into new segments, especially toward the input production and delivery. MFD diagnostics analyzed 51 activities across the coffee value chain and found that there can be potential for private sector engagement toward input and research and development. Coffee seedling production and distribution; organic and in-organic fertilizer production and distribution; warehousing; quality management and certification services; extension support through direct procurement; and PPP in coffee research and facilities management are some areas of potential private sector engagement. The MFD diagnostics have identified some potential areas, which need to be further analyzed, discussed, and prioritized for action by industry and government for increasing private sector investment in the coffee value chain.

Maize is an important crop for household food security and has significant potential for livestock feed and meeting domestic and export markets for human consumption. The areas around improved maize seed production and distribution; organic and inorganic fertilizer production and distribution; mechanization services (production and post-harvest processing); agro-chemical production and delivery; agronomic advice and pest management; warehousing and storage are potential areas for increased private sector engagement which would require creating a level playing field and amendment in regulations and policies in the maize sector. The MFD diagnostics have identified few other potential actions which could be considered for further discussion and analysis by the government as it pursues the reform agenda.

The agricultural sector is dominated by small, mostly informal enterprises, across the board, especially in processing, marketing, and distribution. Formal sector, medium, and large enterprises, are relatively limited and concentrated in the export sector (coffee, sesame, floriculture, processed meat). This structure creates significant limits on potential investment, despite the needs surrounding informal small enterprises. The current business enabling environment puts a limit on potential growth (in scale of operations or diversification into related activities) of such enterprises. Access to finance is severely limited, constraining any potential financial investments by such enterprises. 
Limited agricultural finance is one the biggest challenges for private sector investment. During 2017 in Ethiopia, only $12 \%$ of total loan disbursement by commercial banks was classified as loans to the agricultural sector. The majority of these loans were provided to (a) large scale commercial farmers, (b) coffee and sesame exporters, and (c) cooperative unions. MFIs and Savings and Credit Cooperatives (SACCOs) do provide some financing in rural areas, but the average loan value is much smaller and not appropriate for the requirement of the agricultural sector. The private sector, across the value chain, needs access to finance to effectively function and upgrade their operation. Unless the underlying financial sector issues, specifically agricultural finance, are addressed, there will be limited liquidity, hence limited investment by the private sector in agriculture. While addressing the overall financial sector issues, specific financial products meeting the agricultural sector's requirements need to be designed and delivered.

There are significant opportunities for fostering new public-private partnerships, especially in areas of operations and management of public assets. Improving the overall business enabling environment and entrepreneurship is a priority for the country. Purely public investments are related directly to the need to improve road, water, and electricity infrastructure, telecommunication coverage, and investment in skills development.

Applying the MFD diagnostic has identified a wide-ranging set of options that can be considered for improving the investment environment for enhanced private sector participation. Some require private sector action, others policy amendments, and the design and implementation of supporting programs.

Therefore, it is recommended that ownership of the process sits with both the GoE and private sector actors. A subsector forum should be created for each commodity where actors from across the VC can raise concerns, propose and agree on solutions, and monitor the effectiveness of implemented recommendations.

The World Bank and IFC are embarking on a two-year technical assistance program for agricultural policy and regulatory reform in FY 2020. The findings from this MFD exercise will help identify priorities for regulatory and policy reform. The technical assistance (TA) program will support the Ministry of Agriculture, the Prime Minister's office, and the GoE to reform regulations and policies. In addition, IFC and World Bank will be conducting a deep-dive analysis in agribusiness, as a next step of the Country Private Sector Diagnostics, which will also inform the agricultural policy and regulatory reform TA program. 


\section{Introduction}

1. This chapter: (a) sets out the rationale for the need to create an enabling environment for a greater level of investment by the private sector as a means of sustaining the high growth rates of the Ethiopian economy, which to date has benefitted from the state-led model which is not sustainable; (b) describes the Maximizing Finance for Development (MFD) diagnostic as a tool to identify the constraints to crowding in private sector investments as contributor to development goals, which enables the identification of possible actions for both the public and private sector to consider; and c) explains the rationale for selecting the three sub-sectors of beef, coffee, and maize for the study. For those readers wanting a deeper insight to the MFD methodology refer to 9.2, Annex 1.

\subsection{Country Context}

2. Ethiopia has sustained an average growth of approximately 10 percent over the past decade, making substantial strides in social and human development. This strong, sustained growth performance has contributed to a decline in the poverty rate from 44 percent in 2000 to 23.5 percent in 2016. The state-led model of development has seen this tremendous growth driven primarily by public investments. Of the three major sectors, industry registered the strongest growth, driven largely by the construction sector fueled by public expenditure on mega-infrastructure projects.

3. The agricultural sector is the dominant sector in the Ethiopian economy. The agricultural growth average of $7.6 \%$ per year over the last decade contributed significantly toward poverty alleviation, each year reducing poverty by $0.9 \%$. Although there is an on-going structural transformation in the Ethiopian economy, predominantly from agriculture to services and manufacturing, agriculture still comprises 36 percent of GDP, 70 percent of employment, and 80 percent of exports. Agricultural growth has been driven by strong yield growth and increases in areas cultivated, which increased by 7 and 2.7 percent per year in 2004 and 2014, respectively. Significant increases in the adoption of improved seeds and fertilizer and large public investment in the sector, including agricultural extension, rural roads, small scale irrigation for instance, played a major role in sustaining higher yields.

4. Despite the impressive gains made in improving yields in Ethiopian agriculture over the past decade, there are significant challenges that are limiting the transformation of agriculture sector. The sector is still predominantly subsistence-level for meeting household need (79 percent of maize is consumed by farming households) rather than commercialization for market consumption. The usage of technology is still limited, and only 13 percent of the total cereal cropped area is covered by improved seed. While the figure for pulses and oil seeds was $0.9 \%$ and $1.8 \%$ of the total pulse and oil seed cropped area were under improved seed, respectively ${ }^{1}$. Close to 50 percent of farmers does not have access to fertilizers. Ethiopia has one of the lowest levels of agricultural mechanization in SubSaharan Africa. Agricultural credit and other financial services for smallholder farmers is at a nascent stage.

5. The State has invested heavily in the agricultural sector and Ethiopia is one of the few countries which has surpassed the Comprehensive Africa Agriculture Development Programme (CAADP) target of investment in agriculture. According to CAADP, Ethiopia has $16.8 \%$ of public agriculture expenditure as the share of total public expenditure. In comparison, neighboring Kenya has $2.3 \%$.

\footnotetext{
${ }^{1}$ Central Statistical Agency (CSA) Key Findings of the 2016/2017 Agricultural Sample Surveys, August 2017.
} 
6. Though the state-led model played a significant role in achieving growth, in the current macroeconomic environment the affordability and financial sustainability of the required investments and existing debts are proving difficult to maintain in the context of the state-driven model. The rapid expansion of public infrastructure investment is reaching its limit both in terms of external debt sustainability and the crowding out of the private sector in the credit and foreign exchange markets. Additionally, there is a recognition in some quarters that Ethiopian agriculture has seen significant 'growth', but the accompanying 'transformation' hasn't happened at the scale and the pace that policy-makers envisioned. Furthermore, the rate of agricultural growth is slowing down. Thus, new approaches are needed to sustain and accelerate its growth.

7. So far, public institutions and programs have been primarily responsible for provision of goods and services for agricultural sector. Through a set of instruments, restrictive policies and regulations, restricted access to land, finance, distribution channels and different incentives, public programs have crowded out private sector in many activities. Private sector could potentially delivery these goods and services at scale, much lower costs, and more efficiently than the public sector and contribute to much needed transformation in agricultural sector.

8. The state-led model of development that has driven growth over the past 15 years has been facing increasing challenges. Under a new Prime Minister and government, greater political freedoms are being accompanied by recognition of the need to provide more space for private sector involvement in the economy. The Government is revising its growth strategy to allow for a much larger role for the private sector in driving growth and job creation. This also necessitates a reassessment of the role of the public and private sector in agriculture.

9. The financing needed in Ethiopian agriculture is huge. Despite the massive investment by the State, there is a significant financing gap in realizing the full potential of the Ethiopian agricultural sector. Crowding in private investment and optimizing the use of scarce public resources will be needed, as will the continued promotion of good governance, environmental, and social sustainability. Increasing private sector investment and associated financing will require identifying and understanding market failures currently leading to the sub-optimal private provision of goods and services needed to achieve key development goals. Prioritizing country level actions can be informed by private sector oriented diagnostics as well as by active and effective public-private dialogue mechanisms to define a reform and investment agenda that ensures impact. To help achieve this, the World Bank Group has developed a new diagnostic approach called Maximizing Finance for Development (MFD) approach.

\subsection{The MFD Approach}

10. Considering the ongoing reform process in Ethiopia and an appetite for potential agricultural policy and regulatory reform, this led the World Bank and IFC to pilot MFD diagnostics in Ethiopia. The Maximizing Finance for Development (MFD) in Agriculture and Food Systems in Ethiopia analysis has been undertaken in coordination with the Ministry of Agriculture (MoA) and in partnership with the Agricultural Transformation Agency (ATA).

11. MFD in Ethiopia should be seen as a process. First, the World Bank's MFD process ${ }^{2}$ (refer to Figure 1 ) is deployed to identify functions and activities along the value chain (VC) where the private

\footnotetext{
${ }^{1}$ Refer to Annex 1 for an outline of the World Bank's MFD tool and analytic approach. Reference may also be made to Townsend, R., L. Ronchi, et al. 2018. Future of Food: Maximizing Finance for Development in Agricultural Value Chains. World Bank. https://www.worldbank.org/en/topic/agriculture/publication/the-future-of-food-maximizing-finance-fordevelopment-in-agricultural-value-chains.
} 
sector is involved or not together with issues and constraints faced across the VC functions. The results provide a range of opportunities for either the public or private sector to consider, with the purpose of crowding in more private sector investment and sustainable solutions to achieve the Sustainable Development Goals (SDGs) and meet the highest environmental, social, and fiscal responsibility standards. This will enable the public sector to meet the highest fiscal responsibility standards and reserve scarce public financing for areas where private sector engagement is not optimal or available. As a second step, the ouputs of this report can be used for further stakeholder engagement to prioritize issues and assess which solutions should be pursued and how they might be operationalized.

12. The MFD analytic approach is not a conventional VC study but it considers each VC function to assess underlying causes of market failure resulting in the suboptimal private provision of goods and services to achieve key development goals. The approach follows what is termed the MFD algorithm, which is a cascade of sequential steps to assist in the analysis and solution formulation of opportunities for scarce public sector investments to enhance private sector investment. 


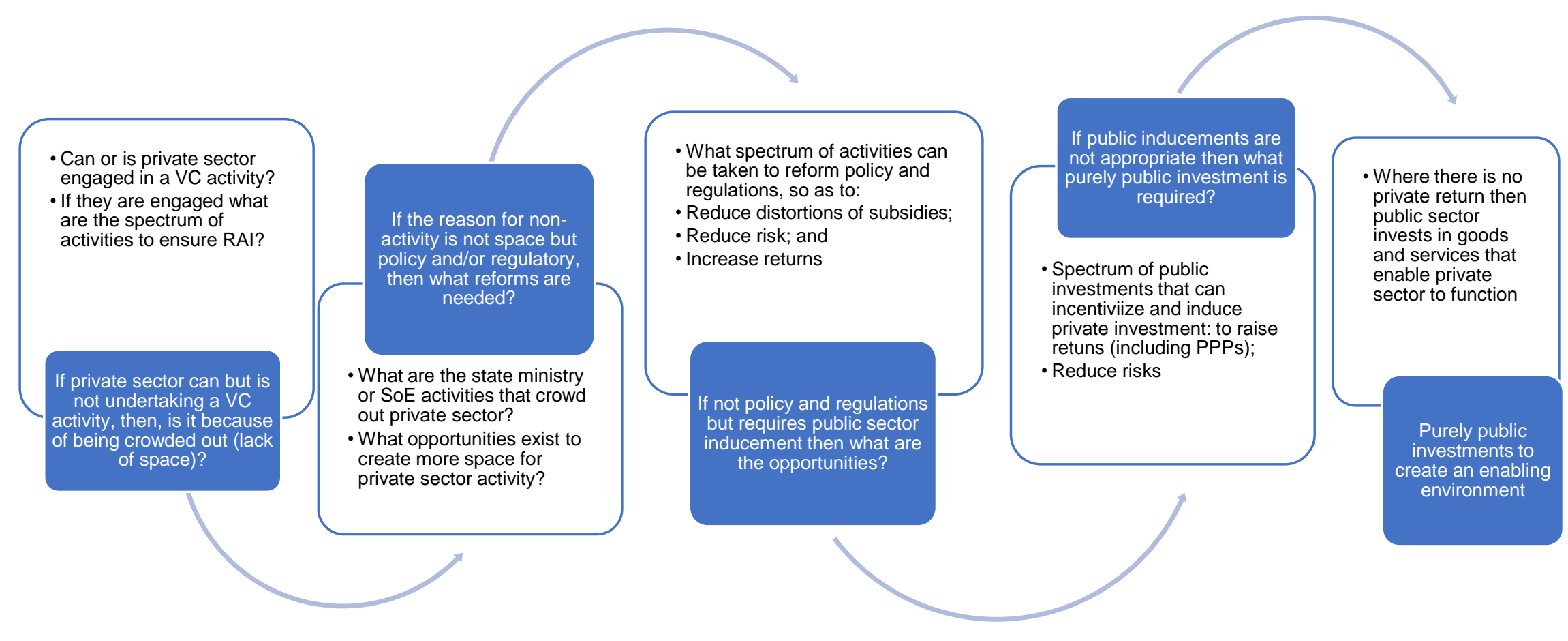




\subsection{Study Methodology}

13. This report identifies the issues and constraints in the three VCs of beef, coffee, and maize, with proposals for (a) the public sector to amend policy and regulations and provide inducements for greater private sector activity or for more focused purely public sector investment and (b) the private sector to address actions for a greater level of responsible agricultural investment ${ }^{3}$ (RAI) aligned with global good practice.

14. The three value chains were selected by the project team in consultation with the Ministry of Agriculture (MoA) based on their significance in terms of food security, Agribusiness industry demand, contribution to the economy, including exports and potential for smallholder impact. A synopsis of each VC's selection criteria is below.

(a) Beef: on the basis of the national herd size, which is the largest in Africa, and ownership is spread across 9.48 million households (Shapiro et al. 2017) and has significant domestic consumption as well as potential export (both as live animals and meat).

(b) Coffee: on the basis of the size of the sector, its importance to some 15 million people dependent on it and cultivated by some 4.7 million farmers. It is one of the largest sources of foreign exchange and in 2016/17 export earnings reached US\$897 million.

(c) Maize: as a subsistence crop, cultivated by about 9 million smallholder farmers, is an important raw material for the food and feed sectors and where aggregate outputs have shown significant upside growth.

15. The following methodology (see detailed description of the methodology in Annex 1 ) has been applied for this diagnostics study:

(a) Reviewing existing VC studies undertaken for providing subsector context and identifying activities across different segments of the value chain.

(b) Hosting an inception workshop with key subsector actors during which the MFD methodology was shared with participants. A preliminary assessment of an institutional mapping of activities across VC functions for each of the three subsectors, with constraints and opportunities, was presented and feedback solicited from participants. Inputs from the workshop contributed to the finalization of the design of a semi-structured questionnaire for use in the field.

(c) Conducting interviews with a cross-section of key VC subsector informants, both in the private and public sector. Interviews were conducted with 60 respondents during December 2018 and January 2019.

(d) Applying qualitative data analysis software and collating the responses from the interviews, grouping them in alignment with the MFD algorithm to identify issues and potential solutions.

(e) Presenting the summative outputs from the assessment to three roundtables of subsector actors and experts, one for each subsector. The discussion and further recommendations added insights to the desktop reviews and interviews and have been included in the context and recommendations contained herein.

${ }^{3}$ RAI Technical Guidance Notes and Tools may be sourced from the World Bank Group though the link: https://www.worldbank.org/en/topic/agriculture/publication/responsible-agricultural-investment. 


\section{Doing Business in Ethiopia}

16. This chapter further illustrates the importance of the need for greater private sector contribution to the economy by referencing three studies. The Ease of Doing Business and Enabling of the Business of Agribusiness, World Bank studies benchmark Ethiopia relative to some of its regional peers, highlighting areas in need of improvement. The Country Private Sector Diagnostic illustrates the need to enhance efficiencies in key sectors that support investment in agriculture and the three value chains under review.

17. Over the past decade, especially following the Growth and Transformation Plan (GTP), the Government of Ethiopia have been slowly opening up and have created some space for private sector to operate. This has entailed privatization of some State-owned Enterprises, opening up some segments of the economy, especially manufacturing and industries, and a heavy emphasis on attracting Foreign Direct Investment (FDI). In the Agricultural sector, two notable segments have witnessed significant FDI. These are: Floriculture Industry and large-scale commercial agriculture wherein large tracts of land have been provided to investors to undertake commercial agriculture. In both cases, significant incentives, access to lands, duty free imports of material, machinery, and tax breaks were provided to foreign investors.

18. Agribusinesses confront many of the same challenges that any private sector business operating in Ethiopia faces, in addition they also face multiple sector specific challenges. Despite all the positive efforts by the Government of Ethiopia, the enabling environment is still quite challenging for private sector operators. An overview of recent studies that are indicative of how the Ethiopian private sector benchmarks against other countries point out the areas of improvement in policy and regulations that could help to achieve greater private sector investment.

19. According to Ease of Doing Business 2019 (World Bank 2018a), (http://www.doingbusiness.org), Ethiopia ranks 159 out of 190 countries and performs poorly compared to the regional average of Sub-Saharan Africa with a score of 49.06 out of 100, where 100 represents the top-performing country (refer to Figure 2).

Figure 2: Doing Business 2019 - Ease of Doing Business Score

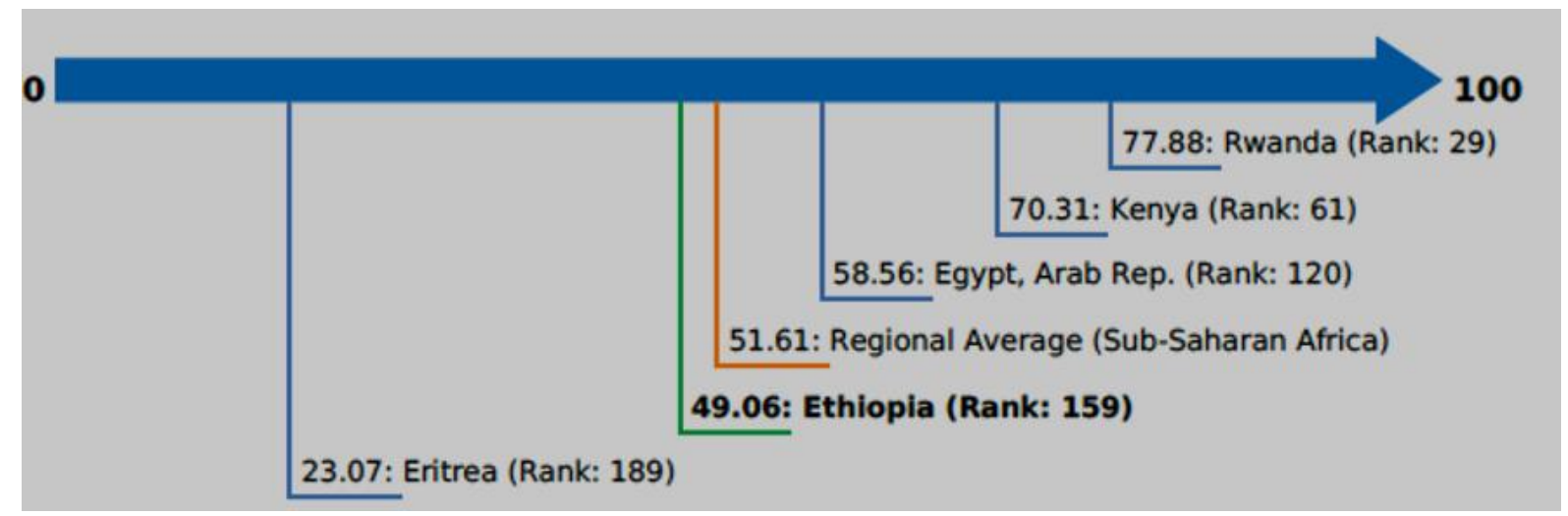

(Source: World Bank; Ease of Doing Business, 2018) 
20. In terms of ranking across several topics, as depicted in Figure 3, Ethiopia has significant room for improvement, with the best ranking of 60 out of 190 countries for contract enforcement to a worst of 178 for protection of minority interest in a business. The latter is especially relevant to foreign investors limited to minority stakes in joint ventures (JVs) with domestic investors. Getting credit, starting a business, trading across borders, and getting access to electricity all rank low with a large performance gap, with this MFD study confirming these business challenges.

Figure 3: Ethiopian Rankings on Doing Business Topics

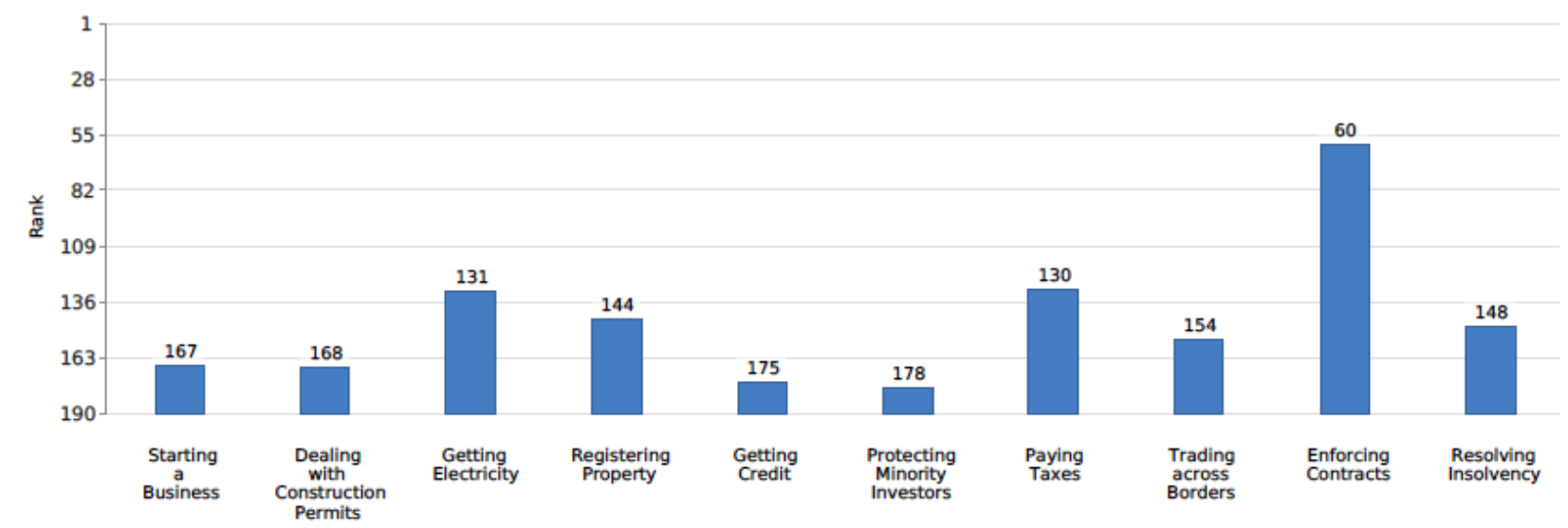

(Source: World Bank 2018a)

21. To deep dive into agribusiness, the World Bank has developed Enabling the Business of Agribusiness (EBA) approach (World Bank 2017, https://eba.worldbank.org) in which the study ranks how a country performs out of 62 others across a series of agricultural measures and the gap in performance with the top-performing country. The results for Ethiopia compared to several regional peers is presented in Table 1. The top-ranked out of the comparative group is highlighted in green and the bottom performer in orange. These scores point to challenges and constraints and opportunities for improvement.

22. In overall business enabling environment, Ethiopia is ranked near the midpoint and below compared to all other counties with significant gaps between performance and the top-performing country across all measures recorded. Performance in the fertilizer sector is particularly weak where Ethiopia is ranked last compared to regional peers at 59 out of 62 countries with a gap of 80.36 percentage points between it and the top performer. Both Kenya and Rwanda feature as top performers in three measures each, while Sudan is the worst performer being in last position in four measures. 
Table 1: EBA - Ethiopia ranking relative to selected regional economies and its distance-to-frontier (DTF) score

\begin{tabular}{|l|c|c|c|c|c|c|c|}
\hline \multicolumn{1}{|c|}{ Country } & Seed & Fertilizer & Machinery & Finance & Markets & Transport & Water \\
\hline Ethiopia & $39 / 51.07$ & $59 / 19.64$ & $25 / 55.95$ & $27 / 52.96$ & $51 / 45.69$ & $21 / 66.69$ & $34 / 46.94$ \\
\hline Kenya & $7 / 79.24$ & $43 / 41.07$ & $29 / 53.81$ & $10 / 74.33$ & $59 / 32.98$ & $16 / 68.69$ & $4 / 85.04$ \\
\hline Sudan & $41 / 49.34$ & $56 / 23.21$ & $27 / 54.87$ & $53 / 33.93$ & $61 / 30.56$ & $47 / 43.46$ & $59 / 10.17$ \\
\hline Uganda & $31 / 57.82$ & $40 / 46.75$ & $31 / 53.21$ & $31 / 50.30$ & $45 / 50.44$ & $18 / 68.17$ & $26 / 58.58$ \\
\hline Rwanda & $60 / 20.21$ & $38 / 52.58$ & $41 / 43.37$ & $7 / 80.63$ & $47 / 49.30$ & $27 / 62.70$ & $32 / 50.00$ \\
\hline
\end{tabular}

Note: Results are presented as rank/DTF, where rank is the position of the country out of 62 measured and DTF is measured as $0-100$, where 100 is a measure of the best performance of any country and thus illustrates the gap between actual and best performance.

23. In addition to Doing Business and EBA, both of which compare countries across various indicator, the Country Private Sector Diagnostics (CPSD) analytic tool does detailed review of country specific challenges and opportunities for private sector engagement. The World Bank Group conducted CPSD in Ethiopia in 2019 and highlighted that the critical development challenge for Ethiopia is job creation with 20 million still in extreme poverty, which highlights the need for addressing market constraints to enhanced private sector activity.

24. Ethiopian growth and development strategies recognize the backbone sectors of telecom, energy, aviation, and logistics. The CPSD points to the need to enhance the efficiencies in the key enabling sectors, especially logistics, telecom, finance, and energy, if private domestic and foreign investment is to be increased. All these are of particular significance as enablers for the private sector to get more involved in the sectors of beef, coffee, and maize.

25. The CPSD recognizes that the agricultural sector is the dominant employer at 70 percent of the population and that it will not be able to sustain the level of workforce growth expected over time. The report concludes that productivity growth and value addition to products such as coffee, beef, and maize can contribute significantly to increasing exports if the business environment is enhanced based on the performance gaps identified in the EBA, Doing Business. and this MFD study.

26. It is further concluded that the foreign exchange situation will continue to remain fragile for the foreseeable future, thus highlighting the need to optimize foreign exchange earnings through export of coffee, both as green bean and value added, processed maize and meat. The need for enhanced private sector investment is vital if further growth and development in these export commodities is to be achieved. 


\section{Agricultural Sector Overview}

27. Agriculture is the principal source of livelihood for millions of households in Ethiopia who are engaged in multiple functions across the agricultural supply chains. This chapter provides a brief overview of agricultural sector, its significance in Ethiopian economy and major trends in the sector. It also provides a brief summary of the major actors involved in performing commercial functions in the agricultural sector.

\subsection{Overview}

28. The agricultural sector is dominated by crop farming; however, livestock is also a major contributor of agricultural GDP. As in the case of other African countries, agriculture in Ethiopia is diverse due to varied local conditions, even across small distances. Nevertheless, two broadly defined production systems can be identified: mixed cereal-livestock farming systems in the highlands, and solely livestock producing pastoralist systems in the arid and semi-arid lowlands. In addition, depending on the specific potential of some areas, cereal-livestock farming systems may be complemented by coffee, sugarcane or horticulture production and pastoralist systems may integrate crop production in agro-pastoralist systems. Mixed cereal-livestock farming may be further differentiated between areas of better agricultural performance with fertile soil and good rainfall and moisture stressed, largely food insecure areas. In some parts of the country (e.g. SNNP), agroforestry where forest trees, livestock, and crops are integrated on the same unit of land is being practiced.

29. Agriculture in Ethiopia is predominantly household-based and subsistence-oriented. It is estimated that 17 million or so farming (and pastoralist) households contribute $95 \%$ of all agricultural (crop and livestock) production and only $5 \%$ of agricultural output is produced by commercial farms (UNDP 2011). As predominantly subsistence-oriented, household-based production units, decisions on production and consumption are inseparable and market transactions are limited, thereby reducing opportunities for growth. More broadly, the integration of agriculture within the national economy remains weak.

30. Most farming households operate extremely small farms ( $39 \%$ of farms are less than or equal to 0.5 hectare and $61 \%$ less than 1 hectare). Although the relationship between farm size and agricultural performance remains ambiguous, from a household income point of view, such small farm sizes suggest that individual farm incomes remain low despite increasing production. The implication is that job creation and agricultural-related employment outside of farming must be important aspects of agricultural transformation.

31. While productivity is improving, yield levels have not reached their full potential. Agricultural yields globally have been increasing since the 1960s. The same is true for Ethiopia. In fact, improvements in agricultural yields in Ethiopia have outstripped global growth over the last $1 \frac{1}{2}$ decades. Nevertheless, yield levels in Ethiopia remain significantly below global averages. Several factors contribute to relatively low productivity in Ethiopian agriculture: (a) the use of improved technologies is sub-optimal, constrained by under-developed input supply systems, limited technology options, and poor incentives; (b) predominance of rain fed production systems with only 4 to $5 \%$ of agricultural land under irrigation and less than 13\% of the country's irrigation potential developed, affecting both productivity levels as well as intensity of agricultural production; and (c) an increasingly unfavorable natural environment - eroded lands and poor soils (both in terms of fertility and soil health) resulting from unsustainable agricultural practices, moisture stressed and arid (or semi-arid) conditions in a large part of the country, as well as erratic weather conditions exacerbated by climate change. 
32. Considering the significance of agriculture in Ethiopia for economic growth, poverty alleviation, food security, and equitable development, the Government of Ethiopia has been heavily involved in most of the functions in the agricultural supply chain, from input to market end. The Stateled Development model has led to government being involved in many commercial and quasicommercial functions, usually performed by the private sector in other countries.

33. The following set of institutions are currently engaged in performing various commercial and quasi-commercial functions in the agricultural sector:

1. Ministry of Agriculture: MoA, through its various departments and units, both at federal and regional level, are engaged in performing multiple functions, from inputs to the provision of marked infrastructure.

2. State-Owned Enterprises: To perform commercial activities, the GoE have established Stateowned Enterprises (SoEs) across value chains from seed production to agricultural machinery production to grain trading. In addition to federal SoEs, many of the regional governments have set up regional SoEs to perform commercial activities in the agricultural sector.

3. Unions and Co-operatives: To help protect the interest of farmers, the government have facilitated formation of co-operatives and unions, who are expected to perform commercial functions on behalf of member farmers. In theory, cooperatives and unions are supposed to be private sector actors, but in Ethiopian context, they can be considered as part of the State apparatus and managed by the MoA. They have monopoly over sale and distribution of fertilizer, channeled by the MoA, and are engaged in input sales, provision of mechanization services, and trading and processing of agricultural outputs.

4. Ministry of Trade: Ministry of Trade is engaged in performing facilitative and commercial functions in the agricultural sector. Ethiopian Grain Trading Corporation (EGTC) and, Ethiopian Commodity Exchange (ECX) are under the authority of the Ministry of Trade.

5. Common Interest Groups (CIGs): To promote employment, increasingly the Government is pursuing the strategy of group enterprises. Individuals are encouraged to form groups (common interest groups) and financial and non-financial support is provided to ClGs to initiate commercial activities across the spectrum of the value chain. $\mathrm{ClGs}$ are still nascent and have limited presence in commercial space but are growing.

6. Informal small enterprises: The agricultural sector, especially in the output marketing side, is dominated by thousands of informal small enterprises. These individuals and families are engaged in direct procurement, bulking, some primary processing, and eventual direct sale to consumers in urban and rural locations. Some of them are registered small firms and pay taxes while many of them are unregistered and outside the tax bracket.

7. Formal enterprises: Large formal enterprises, are primary engaged in the processing and marketing end of the agricultural VCs. They usually procure from traders (informal small enterprises) and do not have direct procurement relationship with farmers. These formal enterprises have commercial links with the Banking sector and are able to make necessary investments for upgrading their facilities or setting up new facilities.

34. The three sub-sectors; coffee, beef and maize together account for more than 50 percent of the agriculture GDP in the country; more than $50 \%$ of export revenue from the sector and significant share of agricultural labor force. The next section provides details and MFD diagnostics of the three sub-sectors. 


\section{Beef Value Chain Overview and MFD Diagnostics}

35. Beef is one of the significant commodities for agricultural sector. This chapter provides a brief overview of the beef value chain and its structure. It describes the roles and responsibilities of various actors in the beef supply chain and identifies a spectrum of key potential actions to leverage private sector investments in the supply chain. Annex 9.2 provides a detailed description of the beef value chain, describes institutional mapping, highlights major constraints and challenges, and describes potential opportunities for leveraging private sector financing.

\subsection{Overview}

36. Ethiopia is known for its large livestock population of about 55.2 million head of cattle, as well as a diverse agroecology suitable for a range of livestock species. The direct contribution of livestock (including all livestock plus processing and marketing) to GDP is estimated, in 2013, at ETB 186.3 billion per year, or 21 percent of GDP and 49 percent of the agricultural GDP (Shapiro, Getachew, et al. 2017). This percentage is likely to increase in the coming decades, with the subsector remaining a significant contributor to the gross value of agricultural products. Of the ETB 186.3 billion GDP contribution, beef, excluding hides and skins, accounts for ETB 43.4 billion ( 23 percent). The value addition component within these statistics is about 19 percent of the primary production contribution, compared to 100 percent and above for some neighboring OECD countries.

37. Despite available resources and conducive factors for livestock development, consumption of animal based-food like meat and milk is one of the lowest among the Sub-Saharan African countries. Per capita meat consumption is estimated to be $8.5 \mathrm{~kg}$ (Sileshi et al. 2014). As incomes and urbanization increase, growth in consumption should also increase, leading to opportunities for investment.

38. Production systems are under continuous change, in part as a response to the emerging urban markets and to changes in rangeland conditions. Small-scale fattening of cattle (4-10 units per feedlot) for income generation are flourishing in many areas. The numbers of commercial feedlots, with a capacity of fattening $200-5,000$ head of cattle have also increased over the last 15 years. On the other hand, rangelands are being negatively affected by bush encroachment, reducing the grazing for the national herd.

39. About 60 percent of livestock export earnings come from live animal export. Animals are transported from primary market to final market on general purpose trucks. Dedicated livestock transport services, particularly for cattle, do not exist in Ethiopia. Unsuitable transportation leads to negative animal welfare issues. Further, the negative quality impact on meat from improper handling of animals during transportation can be significant, resulting in lower grades and a negative knock-on impact on carcass price.

40. Export demand of Ethiopian beef is fairly limited and requires promotion. Many of the export abattoirs are not equipped to slaughter cattle and processing beef. Ethiopian meat is also not competitive with alternative suppliers such as Argentina in the end markets. Meat processing, especially beef processing, is at a nascent stage, and the 17 or so export abattoirs are mainly freezing sheep and goat carcasses for export. There are over 296 municipal abattoirs in Ethiopia, which is projected to increase to 616 by 2020 (MoLF 2017).

41. Currently, veterinary services such as disease surveillance, animal health clinics, meat inspection, vaccine production and distribution, and drugs are mainly provided by the government. Few veterinary drug shops and private clinics are available in major cattle-producing areas and there 
are many small-scale distributors of illegally procured drugs. The misuse of these drugs has resulted in the development of resistance to tick control remedies.

\subsection{Roles and responsibilities in the beef VC}

42. Table 2 presents a synopsis of areas in which the private sector is active within identified VC activities, where it is not, and where it could be. The possible reasons for noninvolvement of the private sector are listed and discussed further in the sections that follow. Column A lists the VC functions and the activities under those functions. The actors, or entities undertaking the activity, are listed in Column B. Column C includes a comment on whether the private sector is involved or could be involved. Column D identifies the possible MFD cascade intervention areas.

Table 2: Synopsis of Private Sector Activity in the Beef VC

\begin{tabular}{|c|c|c|c|}
\hline VC function and activities & & $\begin{array}{l}\text { Comment on private } \\
\text { sector involvement or } \\
\text { not: Could private } \\
\text { sector do it } \\
\text { C }\end{array}$ & $\begin{array}{c}\text { Reasons for } \\
\text { noninvolvement of } \\
\text { private sector: } \\
\text { Possible areas of } \\
\text { intervention } \\
\text { D }\end{array}$ \\
\hline \multirow[b]{2}{*}{$\begin{array}{l}\text { Research and development } \\
\text { - Improvements in Boran breed } \\
\text { genetics } \\
\text { - Management strategies to limit bush } \\
\text { encroachment } \\
\text { - Development of processed meat } \\
\text { products to serve the consumer } \\
\text { market }\end{array}$} & & & \\
\hline & $\begin{array}{l}\text { - FSoE } \\
\text { - FSoE, NGO } \\
\text { - FSoE PS }\end{array}$ & $\begin{array}{l}\text { - PS could do it if } \\
\text { incentivized } \\
\text { - Maintain as State } \\
\text { function } \\
\text { - EIAR mainly with } \\
\text { limited PS action }\end{array}$ & $\begin{array}{l}\text { - Space, PPI } \\
\text { - PPI } \\
\text { - RAI, PI }\end{array}$ \\
\hline \multicolumn{4}{|l|}{ Inputs } \\
\hline - Extension support & - FSoE, SoE & $\begin{array}{l}\text { - PS could do it in a } \\
\text { limited way }\end{array}$ & - RAI, Space, PPI \\
\hline - Production of drugs and vaccines & - FSoE & $\begin{array}{l}\text { - NVI PS could do it as } \\
\text { PPP with FSoE }\end{array}$ & - Space, PI \\
\hline $\begin{array}{l}\text { - Sales and distribution of drugs and } \\
\text { vaccines }\end{array}$ & - FSoE, PS & $\begin{array}{l}\text { - PS (informal) does it } \\
\text { but needs more resp. } \\
\text { PS activity }\end{array}$ & - RAI, P\&R \\
\hline - Feed testing and regulation & - FSoE & $\begin{array}{l}\text { - NVI, PS could do } \\
\text { testing }\end{array}$ & - P\&R, Space \\
\hline - Feed formulation and sale & - PS, COOP & $\begin{array}{l}\text { - PS does it but could do } \\
\text { more }\end{array}$ & - RAI, P\&R \\
\hline - Pastures & - RGoE & $\begin{array}{l}\text { - PS does it on a limited } \\
\text { basis }\end{array}$ & - Space, PI \\
\hline - Rangeland drinking water supply & - RGoE & - Remain as State & - PPI \\
\hline - Feedlot machinery \& equipment & - PS & - PS does it & $-\mathrm{n} / \mathrm{a}$ \\
\hline - Transport vehicles & - PS & - PS does it & $-P I$ \\
\hline - Abattoir equipment & - PS & - PS does it & $-\mathrm{n} / \mathrm{a}$ \\
\hline - Veterinary health services & - RGoE, PS & $\begin{array}{l}\text { - Remain as RGoE and } \\
\text { PS }\end{array}$ & - RAI \\
\hline - Veterinary inspection services & - FGoE & - PS could do it & $-P \& R$ \\
\hline - Finance & - FSoE, PS, DFI & - PS does it & $-\mathrm{PI}$ \\
\hline - Office supplies & - PS & - PS does it & $-n / a$ \\
\hline - Office equipment & - PS & - PS does it & $-n / a$ \\
\hline - Fuel & - PS & - PS does it & $-n / a$ \\
\hline - Electricity & - FSoE & - Remain as State & - PPI \\
\hline
\end{tabular}




\begin{tabular}{|c|c|c|c|}
\hline $\begin{array}{l}\text { VC function and activities } \\
\text { A }\end{array}$ & $\begin{array}{c}\text { Actors } \\
\text { B }\end{array}$ & $\begin{array}{l}\text { Comment on private } \\
\text { sector involvement or } \\
\text { not: Could private } \\
\text { sector do it } \\
\text { C }\end{array}$ & $\begin{array}{l}\text { Reasons for } \\
\text { noninvolvement of } \\
\text { private sector: } \\
\text { Possible areas of } \\
\text { intervention } \\
\text { D }\end{array}$ \\
\hline $\begin{array}{l}\text { Production } \\
\text { - Pastoralist herds with young and old } \\
\text { stock for sale }(9.48 \text { million households } \\
\text { with herds of } 2-4 \text { animals } \\
\text { - Feedlot fat stock }\end{array}$ & $\begin{array}{l}\text { - PS } \\
\text { - PS }\end{array}$ & $\begin{array}{l}\text { - PS does it } \\
\text { - PS does it }\end{array}$ & $\begin{array}{l}-P I \\
-n / a\end{array}$ \\
\hline $\begin{array}{l}\text { Processing } \\
\text { - Backyard slaughter } \\
\text { - Abattoirs } \\
\text { - Butcheries } \\
\text { - Business registration }\end{array}$ & $\begin{array}{l}\text { - PS } \\
\text { - MGoE, PS } \\
\text { - PS } \\
\text { - FGoE, RGoE }\end{array}$ & $\begin{array}{l}\text { - PS (informal) does it } \\
\text { - PS could do more } \\
\text { - PS does it } \\
\text { - State does it }\end{array}$ & $\begin{array}{l}\text { - P\&R } \\
\text { - Space, PPP } \\
\text { - RAI, P\&R } \\
\text { - n/a }\end{array}$ \\
\hline $\begin{array}{l}\text { Marketing and Distribution } \\
\text { - Certification of collectors, traders, } \\
\text { and brokers } \\
\text { - Sales yards } \\
\text { - Quarantine } \\
\text { - Pastoralist gate aggregators } \\
\text { - Local traders } \\
\text { - Live animal exporters } \\
\text { - Transportation: road, air, and sea } \\
\text { freight } \\
\text { - Meat exporters } \\
\text { - Butcheries }\end{array}$ & $\begin{array}{l}\text { - FGoE, RGoE } \\
\text { - RGoE } \\
\text { - FGoE, PS } \\
\text { - PS } \\
\text { - PS } \\
\text { - PS } \\
\text { - PS } \\
\text { - PS } \\
\text { - PS }\end{array}$ & $\begin{array}{l}\text { - State does it } \\
\text { - State does it } \\
\text { - Selected PS can do it } \\
\text { - PS does it } \\
\text { - PS does it } \\
\text { - PS does it } \\
\text { - PS does it } \\
\text { - PS does it } \\
\text { - PS does it }\end{array}$ & $\begin{array}{l}\text { - PPI } \\
\text { - PPI } \\
\text { - Space } \\
\text { - RAI, P\&R } \\
\text { - Space } \\
\text { - RAI, P\&R, PI } \\
\text { - PI } \\
\text { - PI } \\
\text { - RAI }\end{array}$ \\
\hline
\end{tabular}

Note: Column B: Government administration, either federal, regional, or municipal - FGoE, RGoE, MGoE; Federal State-owned Institute FSol; Federal State-owned Enterprise - FSoE; Regional State-owned Enterprise - RSoE; development finance institution - DFI; cooperative (primary and/or union) - COOP; public-private partnership, where the entity is governed by statute but owned privately - PPP; private sector - PS; and nongovernmental organization - NGO.

Column C: Responsible Agricultural Investment - RAI; space for private sector to operate - Space; policy and regulations - P\&R; public inducements - PI; purely public investment - PPI. Where no specific immediate MFD intervention area has been identified, this is flagged as n/a.

43. A total of 35 activities have been identified across the five main VC functions. Of these, ten that could find more active engagement from the private sector are currently undertaken by the GoE (federal, regional, or municipal), FSoE, PPP, and/or COOP entities. The reasons for limited private sector engagement are described below.

\section{- Research and development}

44. Improvements in Boran breed genetics. Larger commercial feedlots require a sustainable supply of young stock suited to feedlot production systems. If they have access to land to ranch animals (where ranching in the Ethiopian context, given limited land size relative to population can be on a smaller scale, with planted pastures, rather than an extensive rangeland ranch) and receive the necessary permissions, they may be incentivized to import improved genetic material, which in turn could become available to pastoralists and contribute to an improved national herd

45. Development of processed meat products to serve the consumer market. The EIAR undertook some food science research but not specifically in developing beef products suited to the Ethiopian consumer market. There is evidenced by the private sector having imported expertise to develop the meat products business, but they faced challenges in sourcing foreign exchange to remunerate the expat employees. 


\section{- Inputs}

46. Extension support. This is currently almost exclusively a State function through federal and regional state agencies. Private sector feedlots and abattoirs, as part of their procurement strategies, are keen to provide animal health advice to their regular pastoralists suppliers.

47. Production of drugs and vaccines. Currently, this is the exclusive domain of the NVI but has the potential for a PPP with international drug and vaccine enterprises.

48. Sales and distribution of drugs and vaccines. Informal distributors who import substandard drugs and vaccines are a threat to the health of the national herd, as incorrect dosing results in building up resistance to treatments. This requires enforcement of regulations and education of the users and distributors. Facilitating investment in supplying appropriate drugs and vaccines by responsible accredited suppliers could improve the standards of treatment.

49. Feed formulation and sale. Common complaints that feedlot livestock owners face with feed concentrates and formulations are cost, legitimacy of the claimed formulation, and uneven application of VAT across ingredients. This can be addressed by (a) production support to increase the supply of soya, (b) VAT reform for zero rating feed ingredients, (c) registration of animal feeds, and (d) random testing of registered feeds to ensure compliance with the registered formulation. These actions should improve reliability, cost-effectiveness, and trust of the local feed sector.

50. Veterinary inspection services. Abattoirs are subject to inspections to ensure carcasses comply with animal health regulations. Abattoir owners complain of uneven service, which affects business activities (for example, meeting delivery schedules and vets not arriving on time). Accredited private vets could provide this service, with state monitoring.

\section{- Processing}

51. Backyard slaughter. Health hazards related to backyard slaughtering and poor cold chain management pose serious health risks to consumers. Studies highlight some level of noncompliance by abattoir staff and a high level of noncompliance by butchery staff of appropriate health and hygiene measures. Tighter control and enforcement of regulations through inspection and a parallel educational program by the butchery association could improve this situation.

52. Abattoirs. Many municipal abattoirs are reportedly in poor condition and there are plans to expand these further by the municipalities. This investment offers a significant opportunity to either privatize or consider a PPP with the private sector for operation and financing.

\footnotetext{
Ministry of Agriculture Engaged in Production of Industrial Gas (Liquid Nitrogen)

In addition to direct inputs needed for beef value chain, the Ministry of Agriculture is also engaged in performing some ancillary functions in the value chain. A case in point is production of liquid nitrogen, an industrial gas. The livestock sector needs regular access to liquid nitrogen for maintaining the cold chain for livestock semen and animal vaccine storage and distribution. Industrial gas production is a profitable commercial activity and using the liquification process multiple gases such as oxygen, carbon dioxide, argon, and nitrogen (which could be produced in liquid and gaseous form) is produced for various industrial and non-industrial applications across the globe. To meet their requirement for liquid nitrogen, the Ministry of Agriculture currently owns and operates 17 liquid nitrogen production facilities across multiple locations in Ethiopia. The production capacity of these facilities ranges from 5 to 10 liters per day. Currently, out of these 17 facilities, only eight are functional due to various operational and management issues. Considering that animal vaccine production and distribution as well as artificial insemination are being managed by the Ministry of Agriculture, there is limited private market purchase of liquid nitrogen. Since the State is the sole buyer, MoA asserts that it needs to be engaged in production of liquid nitrogen. However, one need to question whether activities, such as liquid nitrogen production, should be a core function of MoA or
} 
whether such activities could be better performed by the private sector through operations and

management (O\&M) contracts, long-term purchase contracts or other forms of Public Private Partnerships.

\section{- Marketing and distribution}

53. Quarantine. Live animal exports are subject to quarantine, which is usually a state function undertaken at a central facility. Recently, some exporters with feedlots have been granted permission to undertake their own quarantine with state inspection. This resulted in improved efficiencies and capacity at state quarantine facilities. This program could be expanded with privatization of inspections using accredited vets.

\subsection{Spectrum of Key Possible Action areas for MFD in the Beef Value Chain}

54. There are significant opportunities for leveraging private sector investments in the beef value chain, however, it will require concerned effort by the Government to further liberalize the sector and open space for private sector engagement. The Government of Ethiopia is currently going through a reform process including reform of State-owned Enterprises, divesting out of some sector such as sugar, privatization of some SoEs, and greater focus on Public Private Partnerships. There is an ongoing dialogue on potential regulatory and policy reform in agricultural sector and increasing appetite from the government end to reform agricultural sector to achieve necessary transformation. Following the MFD approach, the diagnostics identified the following spectrum of potential actions across the five major intervention themes to increase private sector engagement in the beef value chain. There is no clear prioritization of these actions at this stage. The prioritization process needs to be led by the Government of Ethiopia, in collaboration with the various value chain actors, to identify potential area of regulatory reform. Nonetheless, this section provides a long list of options for consideration by the Government.

55. I. Actions to promote responsible food and agriculture investments: The current formal sector engagement in the beef value chain is relatively limited. At this stage, it is mainly comprised of meat processing, export and some ranch operations. Some areas for increasing Responsible Agriculture Investment (RAI), which would require private sector action, could include:

a. Food Safety: Considering the sensitivity and risk involved, food safety regulations need to be consistently applied by the private sector, including abattoirs, retail meat seller, meat processors and other actors in the supply chain. Adoption of relevant food safety standards should be a priority action for the private sector.

b. Promoting Contract Farming: To ensure supply chain traceability and co-benefits, direct contracting relations for procurement of cattle could be supported between abattoirs/meat processors and pastoralists. This could be particularly relevant for pastoral communities in Lowlands where the distance from market is much greater in comparison to the Highlands.

c. Local community development: To ensure equitable benefit to the local communities around abattoirs/meat processors and their sourcing areas, private sectors should consider investing part of their profits for local community development. However, they need to be cautious about over-promising development benefits to communities to avoid false expectations.

d. Feed Quality control: There is strong need to ensure feed sold conforms to claimed nutritional value and acceptable feed quality standards (e.g. managing the aflatoxin issue). Considering the feed sector is still in a nascent stage it needs to build credibility among farmers/pastoralists on the benefit of using improved feed for improved results. 
e. Animal welfare: Traders/transporters and abattoirs/meat processors have an obligation to transport and handle animals in a humane manner and they should promote proper handling skills for their staff.

f. Staff development: Investment in enhancing the human capital of staff contributes to efficiency gains. Staff in abattoirs and meat processing facilities should be properly equipped with protective clothing to comply with food safety regulations and their skills should be appropriately development.

56. II. Actions to increase space for private sector investments: There are market opportunities across the beef value chain, however, the current regulatory and policy environment, does not enable private sector to perform many functions. Many are performed by SoEs or line departments of various ministries which ideally, owing to their commercial nature, could be performed by the private sector. The following actions might help:

1. Regulatory and Policy Reform to promote private sector participation across the value chain. In some cases, the existing regulations do not enable private sector to perform these functions, and in other cases, while one set of regulations enable their participation, but a second set of regulations could prohibit their engagement. A comprehensive review and reform of all the core and associated regulations, especially toward the input end of the value chain, might be required to ensure active engagement of private sector in the areas where they are currently not engaged in. Some of the initial functions that could provide good opportunity are mentioned below:

a. Livestock vaccines and drug manufacturing and distribution

b. Artificial insemination services

c. Animal health services

d. Distribution and sale of animal health and feed products

e. Breed multiplication and sale

f. Mobile abattoirs for on-demand slaughter

2. Amendment of Existing Regulations: Particularly in the marketing and sales end of the value chain, the regulations do enable private sector participation, however, a review of specific regulations might be required to facilitate and increase participation and flow of investments into these activities.

a. Feedlot regulations: Review land allocation policies at the regional level to achieve faster approval and equitable processes of handling applications and policies and regulations on minimum land sizes for feedlots. Currently, this is set at 5 ha in rural areas and 2 ha in peri-urban areas, but this indicates a certain minimum-size feedlot. This excludes new entrants that may want to start with a small feedlot on a smaller area. The regulations could be amended to link feedlot capacity to size of land required rather than an arbitrary minimum 5 ha or 2 ha. In addition, certifying private feedlots as accredited pre-quarantine stations might be beneficial in comparison to having only a centralized facility.

b. Restricted markets for meat processor exporters: The current regulation prohibits meat processor exporters to sell more than a prescribed limit in local markets. However, at times the prices in the local market are more attractive than international markets. The GoE could consider granting permission for export-oriented abattoirs to also sell on local markets.

c. Direct Purchase from Pastoralists: Many abattoirs are reluctant to buy directly from pastoralists because the tax authority does not deem that as eligible tax-deductible expenditure, since the pastoralists are not registered as legal merchants. It is difficult 
to get receipts from pastoralist since they are not registered and do not have formal receipts. To promote traceability and direct procurement from pastoralists, the purchase cost of animals by abattoirs from pastoralists should be classified as allowable expenses without question if the buyer has a copy of the pastoralist's ID and a company purchase order.

d. Formalization of cross border trade: More than 70 percent of livestock in pastoral area are traded informally across the border. However, this is considered illegal trade and classified as 'contraband'. This trade has possibly been going on for centuries propelled by social, cultural and commercial ties. The current policies and regulations around this informal trade should be reviewed with an objective of facilitating and formalizing this informal trade to crowd in private investment.

3. Reassess role of public sector and drop activities which are not core functions: Currently, line department and SoEs are performing some functions which could be performed more efficiently by private sector. GoE should conduct an activity audit of all the functions being performed by various departments, Ministries, and SoEs and accordingly focus on core aspects and liberalize other activities. Some activities where the State could drop the provision role and play a regulatory role include:

a. Liquid nitrogen production

b. Vaccine manufacturing

c. Municipal abattoirs

4. Public-Private Partnerships: GoE have recently developed a PPP strategy and road map, however, is it focused on the infrastructure sector and the agricultural sector is excluded from this PPP roadmap. However, there are considerable opportunities for engaging private sector though different PPP mechanisms. Some functions to consider could be:

a. Operation and management of cattle markets

b. Certification and quality control services

c. Inspection services

d. Management and operations of Municipal Abattoirs

e. Management of Quarantine centers

5. New Opportunities: In Ethiopia, there is a directory detailing business types which exhaustively classifies all the potential businesses that qualify for licensing. If an activity is missing from that directory, that business cannot be permitted. However, in the current dynamic environment, new business opportunities emerge and should be allowed to operate. For example, mobile abattoirs are potentially more appropriate for Ethiopia, rather than the construction and investment in over-capacitated abattoirs. However, current regulations do not include registration of these abattoirs and so they cannot be approved for use. To promote a more dynamic environment, space should be provided to create new types of businesses in all sectors expeditiously.

57. III. Actions to improve the policy and regulatory environment for private sector investment and to reduce the distortionary effects of public spending: There are broader enabling environment issue for the agricultural sector as well as broader business environment and are described in detail in the cross-cutting issues in Chapter 7.

58. IV. Public investment to reduce private sector transaction costs and risk: These actions are difficult for an individual private sector company to finance, however, when in-place, they greatly improve the performance of individual companies and are necessary public investments to create an enabling environment for greater private investments into their core businesses. 
1. Beef value chain alliance: Implement a subsector stakeholder forum or a value chain alliance to create meaningful dialogue on problems, solutions, and actions.

2. Food safety systems: Establishment of national food safety system will formalize the beef value chain and crowd in more private investment.

3. Disease Surveillance and Management System: High risk of disease in cattle necessitates development of a national disease surveillance and management system. Increasingly, this is becoming a cost-of-doing business in international markets and require public investments to ensuring access to international markets.

4. Quarantine systems: Entry into and expanding access to international markets for beef requires FMD- and RVF-free zones of production. This could include the investment in physical control barriers and implementation of an animal traceability system.

5. Skill development and industry capacity building: Technical and management training support to address knowledge gaps on industry challenges and how to manage them is critical. Consideration could be given to contract experts to impart knowledge through seminars and demonstrations.

6. Consumer education: Increasing consumer awareness about issues of meat quality and food safety is required to modernize the beef sector. This will require investment from public resources and needs to be facilitated by industry association.

7. Market Infrastructure: GoE could invest in livestock market infrastructure with proper facilities like shade, feeding troughs, and water. This would require a management support plan to ensure upkeep and some kind of revenue raising mechanism to maintain infrastructure.

59. V. Use public resources to invest in public goods and services: These are actions which are public goods in nature and there are limited commercial incentive for private businesses to deliver these functions. At the same time, the provision of these goods will help in improving the overall supply chain efficiency.

1. Bush Encroachment Control: Invasive species infestations, especially prosopis juliflora have become a key problem in pastoral areas, which significantly reduces availability of pasture for livestock production. Measure for bush encroachment control, with community involvement, could promote the environment for improved cattle production.

2. Natural resource management: Improving pastoral production systems would require public investment in soil and water conservation, pasture enclosure, and afforestation activities to improve the supply of fodder for livestock.

3. Water development: Stock-watering facilities along the cattle corridors, quarantine stations and marketplaces are essential, and pastoral areas would benefit from animal watering points.

4. Conflict management: While peripheral to the beef value chain, active conflict in pastoral areas negatively affect the performance of the beef value chain. Conflict management and monitoring mechanism is another public good which could support the private sector engagement.

5. Basic research: Basic research on breed improvement, animal health, fodder and feed improvement, good cattle management practices are some core public investments that will be required.

6. Basic Services: Access to basic services, road, water and electricity will be necessary public investment to improve trade and facilitating private investment.

60. Beef value chain has sizable opportunities to meet the rising domestic demand as well as potential export market demand. MFD diagnostics has identified potential spectrum of actions that could help leverage private sector investment as well as improve performance of the beef value chain and generate jobs. A joint industry and government led prioritization process could help narrow down the actions and identify area of regulatory and policy reform that require further analysis, discussion, and consensus building. 


\section{Coffee Value Chain Overview and MFD Diagnostics}

61

Coffee is the primary export earner for Ethiopia. This chapter provides a brief overview of the coffee value chain and its structure. It describes the roles and responsibilities of various actors in the supply chain and identifies a spectrum of key potential actions to leverage private sector investments in the supply chain. Annex 9.3 provides a detailed description of the value chain, describes institutional mapping, highlights major constraints and challenges, and describes potential opportunities for leveraging private sector financing.

\subsection{Overview}

62. Coffee is a major agricultural export crop that earned US\$897 million in the 2016/17 season, and contributes about 22-30 percent of the annual export earnings from commodities (Kufa 2015) and 65 percent of Ethiopia's foreign exchange earnings. There is a high level of local consumption accounting for about 50-53 percent of the total crop. This demand is satisfied by household-level roasting and an ever-increasing number of formal roasting businesses, which indicates the potential for a dynamic private sector supply to this market.

63. From a socioeconomic perspective, coffee contributes to the livelihoods of between 15 million and 20 million people, with the sector generating employment for an estimated 8,000 permanent and 50,000 seasonal casual workers (Birhanu and Daniel 2013; Kufa 2015; Tsegaye 2017; USAID 2010). An estimated 5.4 million ha of land is suitable for coffee production. Of this potential area, estimates of area under coffee vary from as high as 1.2 million ha, with only 0.9 million ha productive in 2009 (Tsegaye 2017) to a low of some 0.662 million ha, which is about 10 percent of the potential (Kufa 2015).

64. In GTP II, the GoE set a goal of more than doubling coffee production by 2020 to achieve a 1million-ton annual target. In 2019, the Ethiopian Coffee and Tea Authority (ECTA) has increased the target to 1.8 million tons by 2024, that is, a tripling of production. While the GTP II target was set in 2015 , the private sector has not yet been able to respond to the opportunity, which is indicative of challenges constraining the realization thereof, especially given that Ethiopia is known as the center of origin for coffee Arabica, with a diverse genetic base of considerable heterogeneity-over 10,000 different varieties. This illustrates the potential to service a range of coffee tastes and preferences and ability for production across a range of micro-climates.

65. The sector is evolving from one dominated by politically connected influential actors in the past to one opening up to improved trading systems, that should facilitate private sector activity and investment. Until recently all coffees had to be traded through the ECX but the 2017 industry proclamation, regulations, and recently released directives grant some 323 registered exporters the ability to buy outside of the ECX trading platform. This will allow better traceability, a requirement of many international markets and may well contribute to better price realization. Currently, it is reported that some 75 percent or 336,000 tons of the 450,000 -ton crop is sold through ECX.

66. There are four types of coffee cultivation in Ethiopia, three of which are by smallholders, with 4.7 million accounting for 90 percent of production. Forest coffee is wild Arabica coffee grown under the shade of forest trees, accounting for 10 percent of output. Semi-forest coffee has some level of tree management, accounting for 35 percent of production. Garden coffee is produced in the farmer's backyard, intercropped with other crops and accounts for 45 percent of total production. Plantation coffee is produced by commercial private investors, contributing 10 percent of total production on about 45,000 ha.

67. Despite the reforms, there is still a long supply chain, which contributes to farmers receiving a reduced share of final price compared to those in other coffee-producing countries. During the 
picking season, smallholder farmers have the option of natural sun-drying at home and later sale to a hulling plant, giving them the option of all-year sales, or sale of fresh red cherry (berry) during a short harvest period. The farmers either sell red cherry to aggregators or directly to a washing station (WS), of which there are about 4,500 , if they are nearby, given the need to ideally process cherry within 1012 hours after picking. Aggregators, with transport, in turn sell to cooperatives, private traders, or direct to WSs. WSs and cooperatives in turn sell to exporters and local roasters, usually through the ECX. Exporters then sell to importing agents. Commercial farmers sell directly to exporters or to offshore markets, so in their case the chain is much shorter.

68. WSs are owned by traders, cooperatives, or are an in-house function of commercial farming operations. Washed parchment bean or hulled, sun-dried coffee is either transferred to a cooperative warehouse or to an ECX regional warehouse, of which there are 22, for grading and storage. Thereafter, it is traded at ECX. Before shipment, it is delivered to a processor for cleaning and grading by some $70-80$ processors located in Addis Ababa.

69. The local Ethiopian coffee sector share of global physical export volumes is between 3.9 and 4.5 percent and in terms of global value, about 2.9 percent, which seems to indicate a relatively lower price realization compared to other producers.

\subsection{Roles and Responsibilities in the Coffee VC}

70. Table 3 presents a synopsis of areas in which the private sector is active within identified VC activities, where it is not, and where it could be. The possible reasons for noninvolvement of the private sector are provided and discussed further in the sections that follow. Column A lists the VC functions and the activities under those functions. The actors, or entities undertaking the activity, are listed in Column B. Column C includes a comment on whether the private sector is involved or could be involved. Column D identifies the possible MFD cascade intervention areas.

Table 3: Synopsis of private sector activity in the coffee VC

\begin{tabular}{|c|c|c|c|}
\hline VC function and activities & $\begin{array}{l}\text { Actors } \\
\text { B } \\
\end{array}$ & $\begin{array}{l}\text { Comment on private } \\
\text { sector involvement or not: } \\
\text { Could private sector do it } \\
\text { C }\end{array}$ & $\begin{array}{l}\text { Reasons for } \\
\text { noninvolvement of } \\
\text { private sector: } \\
\text { Possible areas of } \\
\text { intervention } \\
\text { D } \\
\end{array}$ \\
\hline $\begin{array}{l}\text { Research and Development } \\
\text { - Coffee varieties } \\
\text { - Development and } \\
\text { dissemination of GAP }\end{array}$ & $\begin{array}{l}\text { - FSoE } \\
\text { - SoE, NGO }\end{array}$ & $\begin{array}{l}\text { - Maintain as a State } \\
\text { function until production } \\
\text { is more commercialized } \\
\text { - Maintain as State and } \\
\text { NGO function. } \\
\text { Commercial PS } \\
\text { producers could do it }\end{array}$ & $\begin{array}{l}- \text { PPI } \\
\text { - RAI }\end{array}$ \\
\hline \multicolumn{4}{|l|}{ Inputs } \\
\hline $\begin{array}{l}\text { - Coffee budwood and seed } \\
\text { production } \\
\text { - Saplings (nursery) }\end{array}$ & $\begin{array}{l}\text { - FSoE } \\
\text { - PS, FSoE, NGO, } \\
\text { COOP }\end{array}$ & $\begin{array}{l}\text { - PS could do it } \\
\text { - PS could do it }\end{array}$ & $\begin{array}{l}\text { - Space, PPI } \\
\text { - Space, PI }\end{array}$ \\
\hline - Plastic sleeves & - PS & - PS does it & - RAI \\
\hline - Irrigation pipes and pumps & - PS & - PS does it & $-P I$ \\
\hline - Organic fertilizer & - COOP, PS & - PS does it & - RAI \\
\hline - Chemical fertilizers & - COOP, GoE & - PS could do it & $-P \& R$ \\
\hline - P\&D Chemicals & - PS & - PS does it & - RAI \\
\hline
\end{tabular}




\begin{tabular}{|c|c|c|c|}
\hline VC function and activities & $\begin{array}{c}\text { Actors } \\
\text { B } \\
\end{array}$ & $\begin{array}{l}\text { Comment on private } \\
\text { sector involvement or not: } \\
\text { Could private sector do it } \\
\text { C }\end{array}$ & $\begin{array}{c}\text { Reasons for } \\
\text { noninvolvement of } \\
\text { private sector: } \\
\text { Possible areas of } \\
\text { intervention } \\
\text { D } \\
\end{array}$ \\
\hline $\begin{array}{l}\text { - Harvest baskets } \\
\text { - Hessian bags } \\
\text { - Final product packaging } \\
\text { - Pulping equipment } \\
\text { - Hulling equipment } \\
\text { - Cleaning and grading } \\
\text { - equipment } \\
\text { - Roasting equipment } \\
\text { - Laboratory equipment } \\
\text { - Office supplies } \\
\text { - Office equipment } \\
\text { - Farm tools } \\
\text { - Fuel } \\
\text { - Transport vehicles } \\
\text { - Electricity } \\
\text { - Extension support } \\
\text { - Finance }\end{array}$ & $\begin{array}{l}\text { - PS } \\
\text { - PS } \\
\text { - PS } \\
\text { - PS } \\
\text { - PS } \\
\text { - PS } \\
\text { - PS } \\
\text { - PS } \\
\text { - PS } \\
\text { - PS } \\
\text { - PS } \\
\text { - PS } \\
\text { - PS } \\
\text { - FSoE } \\
\text { - GoE, NGO, PS, } \\
\text { - FSoE } \\
\text { - PS, DFI }\end{array}$ & $\begin{array}{l}\text { - PS does it } \\
\text { - PS does it } \\
\text { - PS does it } \\
\text { - PS does it } \\
\text { - PS does it } \\
\text { - PS does it } \\
\text { - PS does it } \\
\text { - PS does it } \\
\text { - PS does it } \\
\text { - PS does it } \\
\text { - PS does it } \\
\text { - PS does it } \\
\text { - PS does it } \\
\text { - Maintain as a State } \\
\text { function } \\
\text { - PS can contribute more } \\
\text { - PS does it }\end{array}$ & $\begin{array}{l}\text { - n/a } \\
\text { - Space } \\
\text { - Space } \\
\text { - Space } \\
\text { - n/a } \\
\text { - Space } \\
\text { - PI } \\
\text { - n/a } \\
\text { - n/a } \\
\text { - n/a } \\
\text { - n/a } \\
\text { - n/a } \\
\text { - n/a } \\
\text { - PPI } \\
\text { - RAI, PPI } \\
\text { - PI }\end{array}$ \\
\hline $\begin{array}{l}\text { Production } \\
\text { - Red cherry } \\
\text { - Dried cherry } \\
\text { - Transport to hulling or } \\
\text { washing station } \\
\text { - Collectors } \\
\text { - Brokers }\end{array}$ & $\begin{array}{l}\text { - PS } \\
\text { - PS } \\
\text { - PS } \\
\text { - PS } \\
\text { - PS }\end{array}$ & $\begin{array}{l}\text { - PS does it } \\
\text { - PS does it } \\
\text { - PS does it } \\
\text { - PS does it } \\
\text { - PS does it }\end{array}$ & $\begin{array}{l}-P I \\
-n / a \\
-P P I \\
-n / a \\
-n / a\end{array}$ \\
\hline $\begin{array}{l}\text { Processing } \\
\text { - Hulling } \\
\text { - Wet processing } \\
\text { - Certification of WS } \\
\text { - Transport to warehouse } \\
\text { - Grading } \\
\text { - Storage: Warehousing, } \\
\text { weighbridge } \\
\text { - Roasting and grinding } \\
\text { - Certification of roasters } \\
\text { - Business registration }\end{array}$ & $\begin{array}{l}\text { - PS, COOP } \\
\text { - PS, COOP } \\
\text { - RGoE } \\
\text { - PS } \\
\text { - PPP } \\
\text { - PPP, PS } \\
\text { - PS } \\
\text { - FSOE } \\
\text { - GoE }\end{array}$ & $\begin{array}{l}\text { - PS does it } \\
\text { - PS does it } \\
\text { - PS could do it } \\
\text { - PS does it } \\
\text { - PPP (ECX) does it, PS } \\
\text { could do it } \\
\text { - PPP (ECX) and PS do it } \\
\text { - PS does it } \\
\text { - ECTA does it } \\
\text { - State does it }\end{array}$ & $\begin{array}{l}\text { - Space } \\
\text { - Space } \\
\text { - P\&R, PI } \\
\text { - n/a } \\
\text { - Space } \\
\text { - PI } \\
\text { - Space, P\&R } \\
\text { - n/a } \\
\text { - n/a }\end{array}$ \\
\hline $\begin{array}{l}\text { Marketing and Distribution } \\
\text { - Certification of collectors, } \\
\text { traders, and brokers } \\
\text { - Sale of green bean via traders } \\
\text { and brokers } \\
\text { - Certification of exporters } \\
\text { - ECX sale platform }\end{array}$ & $\begin{array}{l}\text { - FSoE } \\
\text { - PS } \\
\text { - FSoE } \\
\text { - PPP }\end{array}$ & $\begin{array}{l}\text { - ECTA does it } \\
\text { - PS does it } \\
\text { - ECTA does it } \\
\text { - PS could do it }\end{array}$ & $\begin{array}{l}\text { - PPI } \\
\text { - Space } \\
\text { - RAI, P\&R } \\
\text { - Space }\end{array}$ \\
\hline
\end{tabular}




\begin{tabular}{|c|c|c|c|}
\hline VC function and activities & $\begin{array}{c}\text { Actors } \\
\text { B }\end{array}$ & $\begin{array}{l}\text { Comment on private } \\
\text { sector involvement or not: } \\
\text { Could private sector do it } \\
\text { C }\end{array}$ & $\begin{array}{c}\text { Reasons for } \\
\text { noninvolvement of } \\
\text { private sector: } \\
\text { Possible areas of } \\
\text { intervention } \\
\text { D }\end{array}$ \\
\hline - Exporters & - PS & - PS does it & - RAI, P\&R \\
\hline $\begin{array}{l}\text { - Cleaning, grading, and } \\
\text { bagging }\end{array}$ & - PS & - PS does it & $-n / a$ \\
\hline $\begin{array}{l}\text { - CLU export quality } \\
\text { certification }\end{array}$ & - GoE & - PS could do it & - Space \\
\hline - Freight forwarding & - PS & - PS does it & $-n / a$ \\
\hline $\begin{array}{l}\text { - Transportation: road and sea } \\
\text { freight }\end{array}$ & - PS & - PS does it & - Space \\
\hline - Sale of roasted coffee & - PS & - PS does it & - PI, RAI \\
\hline - Coffee shops & - PS & - PS does it & $-n / a$ \\
\hline - Supermarkets & - PS & - PS does it & - RAI \\
\hline
\end{tabular}

Note: Column B: Government administration, either federal, regional, or municipal - FGoE, RGoE, MGoE; Federal State-owned institute FSol; Federal State-owned Enterprise - FSoE; Regional State-owned Enterprise - RSoE; development finance institution - DFI; cooperative (primary and/or union) - COOP; public-private partnership, where the entity is governed by statute but owned privately - PPP; private sector - PS; and nongovernmental organization - NGO.

Column D: Responsible Agricultural Investment - RAI; space for private sector to operate - Space; policy and regulations - P\&R; public inducements - PI; purely public investment - PPI. Where no specific immediate MFD intervention area has been identified, this is flagged as n/a.

71. A total of 51 activities have been identified across the five main VC functions. Of these, nine that could find more active engagement from the private sector are currently undertaken by the GoE, FSoE, PPP, and/or COOP entities. The reasons for limited private sector engagement are described below:

\section{- Research and development}

72. Development and dissemination of GAP. Large multinationals could take on the responsibility of promoting GAP among smallholders. Large commercial coffee growers could disseminate best practices to neighboring smallholders.

\section{- Inputs}

73. Coffee budwood and seed production. Currently, the public sector maintains a genetic bank through the EIAR (JARC). The private sector could participate in seed multiplication of released seed but is crowded out by JARC.

74. Saplings (nursery). There is a mix in ownership of nurseries by private sector commercial growers for their own use, the ECTA as a federal SoE, NGOs, and cooperatives. Public investment incentives to assist women and youth in this activity could be considered.

75. Chemical fertilizers. The MoA controls the purchase and import of chemical fertilizer, with cooperatives playing the role of distributor and payment collection agency. The private sector does not have the opportunity to participate.

76. Extension support. This is considered a purely public or NGO activity but the private sector could, as part of RAl, provide extension support (refer GAP) to out-growers of privately owned WSs.

\section{- Processing}


77. Certification of WS. This is a regional state function through the extension services which crowds out the private sector. An independent private sector accreditation agent of the government could provide certification to enable private WSs to access markets aligned to RAI, especially where environmental protection is concerned.

78. Grading. ECX undertakes grading of coffee beans that are delivered to their warehouses. With the change in regulations allowing for direct purchases by exporters, it should be possible for an accredited private sector agency to provide independent grading service.

\section{- Marketing and Distribution}

79. ECX sale platform. ECX can be considered a special type of PPP and its mandate is determined by policy and regulations, which to date has crowded out private sector direct transactions. For exporters, this has changed but not for local roasters who are still unable to purchase directly from producers.

80. CLU export quality certification. This is a GoE function that could be undertaken by private accredited cupping and liquoring facilities.

\subsection{Spectrum of Key Possible Actions areas for MFD in the Coffee Value Chain}

81. Recently, the Government of Ethiopia has amended trading regulations of Ethiopia Commodity Exchange to facilitate traceability of coffee and direct interaction between exporters and farmers. The Ministry of Agriculture is in the process of finalizing a contract farming regulation to enable direct contracting relationships between farmers and buyers. At the same time, these is increasing realization that massive investments, especially at production level is required for replacing aging coffee tree, investing in good coffee production practices, and improving resilience of coffee production base to climate change and pest and diseases. While the investment needs at the input side of coffee is immense, the current private sector engagement in input and research and development is minimal. Following the MFD approach, the diagnostics identified the following actions areas across the five major intervention themes to increase private sector engagement in the coffee value chain. These identified actions could feed into ongoing dialogue in the coffee sector as well as the broader agricultural sector policy and regulatory reform.

82. I. Actions to promote responsible food and agriculture investments: Coffee market is one of the most socially and environmentally conscious market with multiple certification schemes for ensuring social and environmental compliance. Private sector could lead many activities in the area of Responsible Agriculture Investment (RAI). This could include:

1. Promoting Contract Farming: Coffee source of origin, traceability and environmental concerns are increasingly prompting buyers to create direct procurement relationship with farmers. The new regulation now enables direct purchase from farmers and promoting contract farming should be supported.

2. Local community development: Helping local communities around the washing stations and coffee procurement areas, would be worthwhile investment for the private sector to build long lasting relationships with the communities.

3. Environment friendly coffee: Considering the environmental concerns, especially around deforestation, action by coffee roasters and exporters to preserve the environment and support afforestation activities would be a prudent investment.

4. Ethical business practices: Development of Coffee Codes of Ethical Business Practice by the exporters and roasters associations to address improved standards, general business 
conduct, and testing for quality, as guidance for training baristas to adhere to a code and be accredited with certification that can be displayed in the coffee shop.

5. Good Agricultural Practices: More buyers could consider providing technical support to smallholders to farmers to incentivize the application of Good Agricultural Practices (GAP). Especially around the productivity improvement practices, environmentally sustainable practices, safe and correct use of chemicals, their storage, handling, cleaning of equipment, protective clothing, and disposal of unused expired chemicals.

6. Waste management: Proper management and disposal of wet processed waste that creates a significant environmental pollutant to freshwater sources requires a responsible response from washing station owners on appropriate waste management.

83. II. Actions to increase space for private sector investments: Among the three value chains considered, coffee currently has the largest volume of private sector engagement. More than 300 exporters are engaged in the coffee value chain, some of them engaged in commercial production of coffee on farmlands, some have out-grower arrangements. Despite the large present, there are still some areas where private sector engagement is currently missing or at minimal scale since, however, the current regulatory and policy environment, does not enable private sector to perform many functions. The following actions might help:

1. Regulatory and Policy Reform: There are significant functions which private sector can effectively deliver, however the current regulatory and policy environment prohibits or doesn't promote active private sector engagement. Some of the following functions have opportunities for significant private sector engagement.
a. Coffee seed production
b. Coffee nursery development
c. Fertilizer production and distribution
d. Retail input sale
e. Warehousing and storage
f. Grading and certification

2. Amendment in Existing Regulations: Recently, GoE, made multiple amendments in coffee regulations, especially around coffee trading and Ethiopia Commodity Exchange functioning, which are welcome steps. The coffee sector is considered overregulated by private sector respondents although regulations are updated periodically by the ECTA. Some regulations which might require rethinking include:

a. Dual trading system: Related companies maintain a dual trading system with traders having both an export and a local trading license, with which they play the market. When the price differential is in favor of local sales, the export product is held back in the hope of a higher price and then regraded to poor quality to be sold at a better price locally.

b. There are restrictions on licensing of local retail outlets for foreign investors or JVs, which may limit the technology and knowledge transfer to local entrepreneurs.

c. Traders are allowed to directly export without going via ECX, but for local market sales they have to use ECX, where they reportedly sell at up to 40 percent lower than what they could achieve through direct domestic wholesale trade.

d. Local roasters are only permitted to buy low grade coffee. Enabling local roasters to also bid for higher graded coffee for the production of quality value-added coffees for the local market could help modernize the local coffee sector. 
3. Public-Private Partnerships: There are number of areas where PPP arrangements could be developed to facilitate greater private engagement. This could include:
a. Warehouse operations and management
b. Coffee training institute for developing skilled manpower for the industry
c. PPP on coffee research with JIMMA Coffee Research Institute
d. PPP for coffee grading and certification services

84. III. Actions to improve the policy and regulatory environment for private sector investment and to reduce the distortionary effects of public spending: There are broader enabling environment issue for the agricultural sector as well as broader business environment and are described in detail in the cross-cutting issues in Chapter 7.

85. IV. Public investment to reduce private sector transaction costs and risk: Coffee value chain is more vertically integrated and there are opportunities for more private investment along the chain. Nonetheless, there are some public investments, which can create necessary enabling environment to reduce transaction costs and risk for private sector.

1. Support Coffee Sector Association: There are several coffee sector associations (exporter association, roaster association, trader association) which should be supported. Efforts should be made to support a coffee value chain alliance which brings the stakeholders (from input to end market) onto the same platform to discuss and resolve issues.

2. Disease Surveillance and Management System: Coffee disease could be big threat for the industry and to effectively manage it, a disease surveillance and management system should be developed to minimize the sector risk.

3. Coffee Replanting Promotion: Aging coffee trees are a big concern for the industry and significant public investments are needed in a coffee replanting program to replace aging trees.

4. Integrated Coffee Sector Management Information System: This is a priority for both the private sector (that is, a market intelligence system on production, forecasts, prices, and quality) and policymakers regarding scale and impact of the sector. Currently, there are differing reported metrics on areas under production, farmer numbers, volumes produced and traded, and price tracking. This will become more challenging with direct buying permitted from washing (wet) and hulling (dry) stations.

86. V. Use public resources to invest in public goods and services: These are actions which are public goods in nature and there are limited commercial incentive for private businesses to deliver these functions. At the same time, the provision of these goods will help in improving the overall supply chain efficiency.

1. Natural Resource Management: To ensure sustainability of the coffee sector, especially in a changing climate, would require investment in soil and water conservation, afforestation management, erosion control, and other natural resource management activities.

2. Basic Coffee Research: Basic research on appropriate coffee varieties, disease and drought resilience, and coffee agronomy is largely a public sector function which might require investments in the coming years.

3. Basic Infrastructure Facilities (water, roads, electricity): Requisite basic infrastructure support (water, roads, electricity) in the coffee growing areas, around washing and hulling stations, and roasting facilities is much needed in Ethiopia and would require public investments. 
4. Skill Development and Industry Capacity Building: Coffee sector requires specialized skills across the value chain. However, there is significant capacity deficit. Skill development and industry capacity building is a critically required public investment.

87. Coffee has sizable investment by the private sector in roasting, blending, processing, and export facilities in Ethiopia. There are opportunities to further increase investments by expanding existing operations as well as entering into new segments, especially toward the input production and delivery. MFD diagnostics have identified some potential areas, which need to be further analyzed, discussed, and prioritized for action by the industry and government to increase private sector investment in the coffee value chain. 


\section{Maize Value Chain Overview and MFD Diagnostics}

88. Maize is one of the primary food crops for Ethiopia. This chapter provides a brief overview of the maize value chain and its structure. It describes the roles and responsibilities of various actors in the supply chain and identifies a spectrum of key potential actions to leverage private sector investments in the supply chain. Annex 9.4 provides a detailed description of the value chain, describes institutional mapping, highlights major constraints and challenges, and describes potential opportunities for leveraging private sector financing.

\subsection{Overview}

89. Maize is a significant cereal crop for Ethiopia in its role as a rural household food source, the scale of production relative to other cereal crops, and the number of farmers who produce maize. Maize is predominately a subsistence food crop. Approximately 88 percent of maize produced in Ethiopia is consumed as food both as green and dry grain. Farm household consumption accounted for 76 percent of total maize production in 2015/16 and the share of maize that reached the market was only about 11 percent.

90. In scale of production, maize accounts for about 30 percent of total cereal production and 20 percent of total area planted to cereals. Close to nine million smallholder farmers produced maize in the 2014/15 meher planting season. In that same year, maize production reached 7.2 million tons, with productivity having doubled over the past decade and yields significantly surpassing yields of other major regional maize producers such as Kenya, Tanzania, and Uganda. This improvement is attributed to both increases in the adoption of modern inputs and expanded access to extension services. For example, many improved seed varieties, both hybrid and open pollinated, have been released and are being used in increasing volumes. That said, adoption of improved technology is still relatively low and there is potential for continued yield increases.

91. Over 95 percent of maize production in Ethiopia is by smallholder farmers (on less than $1 \mathrm{ha}$ ). Inputs such as seed, fertilizer, and chemicals are mostly provided through the government and the cooperative system. Marketing of maize grain is dominated by informal traders with farmer cooperatives and cooperative unions playing a small role. The dominant practice is that village traders buy maize from farmers and sell to local retail markets and wholesalers through brokers. Wholesalers in turn sell to retailers, including millers, as well as to food and animal feed processors, with millers usually being both processors and retailers. Brokers also trade on the large regional market in Addis Ababa or trade through the ECX platform. The Ethiopian Grain Trade Enterprise (EGTE), as a SoE also buys, stores, cleans, and trades in maize.

\subsection{Roles and Responsibilities in the Maize VC}

92. To better understand the current engagement of private sector in performing different functions in the maize value chain, the MFD diagnostics broke down the value chain into 40 discrete functions that need to be performed across the value chain. Table 4 below provides a synopsis of functions in which the private sector is active within identified VC activities, where it is not, and where it could be. The possible reasons for non-involvement of the private sector are provided and discussed further in the sections that follow. Column A lists the VC functions and the activities under those functions. The actors, or entities undertaking the activity, are listed in Column B. Column C includes a comment on whether the private sector is involved or could be involved. Column D identifies the possible MFD cascade intervention areas. 
Table 4: Synopsis of private sector activity in the maize VC

\begin{tabular}{|c|c|c|c|}
\hline VC function and activities & $\begin{array}{c}\text { Actors } \\
\text { B }\end{array}$ & $\begin{array}{l}\text { Comment on private } \\
\text { sector involvement or } \\
\text { not: Could private } \\
\text { sector do it } \\
\text { C }\end{array}$ & $\begin{array}{c}\text { Reasons for } \\
\text { noninvolvement } \\
\text { of private sector: } \\
\text { Possible areas of } \\
\text { intervention } \\
\text { D }\end{array}$ \\
\hline $\begin{array}{l}\text { Research and development } \\
\text { - Seed variety development } \\
\text { - Responses to fertilizer } \\
\text { application levels to develop } \\
\text { production guidelines } \\
\text { - Efficacy of pest and disease } \\
\text { strategies (chemicals, bio- } \\
\text { agents, and so on) } \\
\text { - Efficacy of appropriate } \\
\text { mechanization systems }\end{array}$ & $\begin{array}{l}- \text { FSoE } \\
- \text { FSoE } \\
\text { - FSoE } \\
\text { - FSoE }\end{array}$ & $\begin{array}{l}\text { - PS could do it } \\
\text { - PS could do it } \\
\text { - PS could do it } \\
\text { - PS could do it }\end{array}$ & $\begin{array}{l}\text { - Space, PPI } \\
\text { - Space, PPI } \\
\text { - RAI, PI } \\
\text { - RAI, PI }\end{array}$ \\
\hline $\begin{array}{l}\text { Inputs } \\
\text { - Extension support } \\
\text { - Seed multiplication } \\
\text { - Fertilizer sales and distribution } \\
\text { - Seed sales and distribution } \\
\text { - Chemical sales and distribution } \\
\text { - Hessian sacks } \\
\text { - Fuel } \\
\text { - Electricity } \\
\text { - Mechanical equipment } \\
\text { - Farm tools } \\
\text { - Office supplies } \\
\text { - Office equipment } \\
\text { - Finance } \\
\text { - Feed mills } \\
\text { - Maize mills (food) } \\
\text { - Transport vehicles }\end{array}$ & $\begin{array}{l}\text { - FSOE, RSOE } \\
\text { - FSoE } \\
\text { - FGoE, COOP } \\
\text { - FSoE, COOP, } \\
\quad \text { PS } \\
\text { - COOP, PS } \\
\text { - PS } \\
\text { - PS } \\
\text { - FSoE } \\
\text { - PS, COOP } \\
\text { - PS } \\
\text { - PS } \\
\text { - PS } \\
\text { - FSOE, PS, DFI } \\
\text { - PS, COOP } \\
\text { - PS, COOP } \\
\text { - PS }\end{array}$ & $\begin{array}{l}\text { - PS could do it in a } \\
\text { limited way } \\
\text { - PS could do it } \\
\text { - PS could do it } \\
\text { - Limited PS but can do } \\
\text { it } \\
\text { - PS could do it } \\
\text { - PS does it } \\
\text { - PS does it } \\
\text { - State SoE function } \\
\text { - PS could do it } \\
\text { - PS does it } \\
\text { - PS does it } \\
\text { - PS does it } \\
\text { - PS does it } \\
\text { - PS does it } \\
\text { - PS does it } \\
\text { - PS does it }\end{array}$ & $\begin{array}{l}\text { - RAI, Space, PPI } \\
\text { - Space, PI } \\
\text { - Space } \\
\text { - P\&R } \\
\text { - Space } \\
\text { - n/a } \\
\text { - n/a } \\
\text { - Remain as SoE } \\
\text { - PI } \\
\text { - n/a } \\
\text { - n/a } \\
\text { - n/a } \\
\text { - PI } \\
\text { - PI } \\
\text { - PI } \\
\text { - n/a }\end{array}$ \\
\hline $\begin{array}{l}\text { Production } \\
\text { - Land preparation } \\
\text { - Planting } \\
\text { - Harvest } \\
\text { - Shelling } \\
\text { - Bag } \\
\text { - Transport } \\
\text { - Storage }\end{array}$ & $\begin{array}{l}\text { - PS } \\
\text { - PS } \\
\text { - PS } \\
\text { - PS } \\
\text { - PS } \\
\text { - PS } \\
\text { - COOP, PS }\end{array}$ & $\begin{array}{l}\text { - PS does it } \\
\text { - PS does it } \\
\text { - PS does it } \\
\text { - PS does it } \\
\text { - PS does it } \\
\text { - PS does it } \\
\text { - PS does it }\end{array}$ & $\begin{array}{l}-\mathrm{PI} \\
\text { - RAI, PI } \\
\text { - RAI, PI } \\
\text { - RAI, PI } \\
-\mathrm{n} / \mathrm{a} \\
-\mathrm{n} / \mathrm{a} \\
-\mathrm{PI}\end{array}$ \\
\hline $\begin{array}{l}\text { Processing } \\
\text { - Purchase }\end{array}$ & $\begin{array}{l}-\mathrm{PS}, \\
\text { COOP }\end{array}$ & $\begin{array}{l}\text { - PS (informal) does it } \\
\text { - PS does it }\end{array}$ & $\begin{array}{l}\text { - P\&R } \\
\text { - Space }\end{array}$ \\
\hline
\end{tabular}




\begin{tabular}{|c|c|c|c|}
\hline VC function and activities & Actors & $\begin{array}{l}\text { Comment on private } \\
\text { sector involvement or } \\
\text { not: Could private } \\
\text { sector do it } \\
\text { C }\end{array}$ & $\begin{array}{c}\text { Reasons for } \\
\text { noninvolvement } \\
\text { of private sector: } \\
\text { Possible areas of } \\
\text { intervention } \\
\text { D }\end{array}$ \\
\hline $\begin{array}{l}\text { - Feed manufacture } \\
\text { - Food manufacture } \\
\text { - Bagging } \\
\text { - Packaging } \\
\text { - Storage } \\
\text { - Business licensing }\end{array}$ & $\begin{array}{l}\text { - PS, COOP } \\
\text { - PS, COOP } \\
\text { - PS, COOP } \\
\text { - PS, COOP } \\
\text { - PS, FSoE, } \\
\text { COOP, NGO } \\
\text { - FGoE, RGoE }\end{array}$ & $\begin{array}{l}\text { - PS does it } \\
\text { - PS does it } \\
\text { - PS does it } \\
\text { - PS does it } \\
\text { - PS does it } \\
\text { - State does it }\end{array}$ & $\begin{array}{l}- \text { RAI, P\&R } \\
-n / a \\
-n / a \\
-n / a \\
-P I \\
-P P I\end{array}$ \\
\hline $\begin{array}{l}\text { Marketing and distribution } \\
\text { - Village traders } \\
\text { - Brokers } \\
\text { - Trading platform (ECX) } \\
\text { - Direct sales } \\
\text { - Exporters } \\
\text { - Municipal markets }\end{array}$ & $\begin{array}{l}\text { - PS } \\
\text { - PS } \\
\text { - FSOE (PPP) } \\
\text { - PS, COOP, } \\
\quad \text { NGO } \\
\text { - PS } \\
\text { - MGoE }\end{array}$ & $\begin{array}{l}\text { - PS does it } \\
\text { - PS does it } \\
\text { - PS does it } \\
\text { - PS does it } \\
\text { - PS does it } \\
\text { - State does it }\end{array}$ & $\begin{array}{l}\text { - PPI } \\
\text { - PPI } \\
\text { - Space } \\
\text { - RAI, P\&R } \\
\text { - Space } \\
\text { - PPI }\end{array}$ \\
\hline
\end{tabular}

Note: Column B: Government administration, either federal, regional, or municipal - FGoE, RGoE, MGoE; Federal stateowned institute - FSol; Federal State-owned Enterprise - FSoE; Regional State-owned Enterprise - RSoE; development finance institution - DFI; cooperative (primary and/or union) - COOP; public-private partnership, where the entity is governed by statute but owned privately - PPP; private sector - PS; and nongovernmental organization - NGO.

Column D: Responsible Agricultural Investment - RAl; space for private sector to operate - Space; policy and regulations P\&R; public inducements - PI; purely public investment - PPI. Where no specific immediate MFD intervention area has been identified, this is flagged as n/a.

93. A total of 40 activities have been identified across the five main VC functions. Of these, activities, there are at least ten functions, most of it toward the input side, where the private sector is currently not engaged. The reasons for limited private sector engagement in some of the functions related to inputs, research, and development are described below.

\section{- Seed variety development}

94. GoE agencies undertake seed development research. In other countries, seed variety development is undertaken by large national and multinational enterprises. However, in Ethiopia the regulatory environment does not promote private sector to undertake seed varietal development. If there is advantage in securing the best seed technologies to optimize yield and production, access to the market can be given to the private sector to undertake locally specific research. This research usually goes hand-in-hand with sales and distribution as the results are a means of demonstrating the efficacy of the product to farmers.

\section{- Extension support}

95. Market linkage support is usually the preserve of the public and NGO sector. However, when production systems allow for commercial operations that have a strong business relationship with farmers, then the commercial partner is incentivized to provide extension support to contracted growers as it is in the business' interest to assure sufficient supplies. This support is further incentivized when the commercial partner provides inputs on credit. Providing land access to commercial farming and processing businesses would contribute to the development of such mutually 
beneficial business relationships. Currently, there is limited extension support by private sector, however, the government of Ethiopia is currently in the process of finalizing contract farming regulation and is promoting a pluralistic extension system to enable delivery of extension support by private companies.

\section{- Seed multiplication}

96. Farmers and cooperative managers complain about inadequate or late seed supply from federal seed enterprises. There seems to be a high demand for private company seeds which are more expensive. Multiplication of sufficient quantities of the right seed requires access to sufficient areas of land, preferably with irrigation. Regulations allow private sector to participate in seed multiplication. However, the incentives are not aligned and they favor SoEs who have access to land, credit, farmers, basic and pre-basic seed, and distribution channels. Similar incentives are not provided to private sector, hence their share in the seed multiplication business is quite small.

\section{- Fertilizer sales and distribution}

97. Fertilizer purchase is undertaken by the GoE with demand estimates provided by cooperatives and extension officials. Once purchased on international markets via tender, the products are imported and distributed via cooperatives, who collect payment and transfer these to the GoE. The current regulations and policies do not allow private sector to participate in this function.

\section{- Seed sales and distribution}

98. This is currently undertaken largely through cooperatives and unions. There have been some initiatives of Direct Seed Marking through small-scale, village agri-supplier agencies which need more scaling up. By freeing up space for greater private sector engagement (by creating level playing field between cooperative unions and private enterprises) and incentivizing small-scale, village agrisuppliers, significant jobs could be created in rural Ethiopia.

\section{- Chemical sales and distribution}

99. Purchase and distribution of chemicals is undertaken through a system of Regional State guarantee to cooperatives who then on-sell to members. Consequently, agro-chemicals can be supplied at prices that are significantly cheaper than through small agencies. This is an advantage to farmers. However, in future, the question will be about the cost of the guarantee to the State, which limits the space for the private sector. If the same guarantee were to be provided to smaller retailers, they could then be competitive with cooperative pricing as well.

\section{- Mechanical equipment}

100. Farmers have significant challenges in achieving timely farming operations to optimize the chances of good yields and when harvesting to ensure the crop can be harvested when sufficiently dry to reduce incidence of molds developing. A system of private contractors with small tractors, harvesters, and threshers (shellers) could offer mechanization services to smallholders. However, the current agricultural mechanization policy environment (import duty, spare parts, costs of mechanization) does not enable private sector to deliver mechanization services to farmers at scale. Government, through various programs, delivers machinery to group of farmers or cooperatives and unions, which ideally could be delivered by private sector if the mechanization policy and regulatory environment improves.

\subsection{Spectrum of Key Possible Actions areas for MFD in the Beef Value Chain}

101. Maize is important for household food security. It has potential for animal feed and export to neighboring countries. Despite the maize yield increase over the past decade, less than 11 percent of total maize production is sold by farmers. To meet the market demand for food and feed, there is a dire need to increase significantly yield and production of maize. The current private sector 
engagement in the input side (improved seed, mechanization, chemicals, and advisory services) is fairly limited and offers opportunities for deepening and expanding operations. Regarding marketing and processing, there are opportunities for upgrading the processes, consolidation, and expansion by formal (small, medium and large) businesses. Following the MFD approach, the diagnostics identified the following actions areas across the five major intervention themes to increase private sector engagement in the maize value chain. These potential spectra of actions need to be further analyzed, discussed, and prioritized by industry and the government.

102. I. Actions to promote responsible food and agriculture investments: The current formal sector engagement in the maize value chain is relatively limited and it mostly at the stage of feed processing and maize milling. Some areas for increasing RAI would include:

a. Promoting Contract Farming: Feed mills and maize processors needs access of good quality maize and establishing direct procurement relationships with farmers, will help create mutually beneficial relationship.

b. Food Safety and Aflatoxin: In maize sector, both in food and feed, aflatoxin content is a big area of concern and investments by private sector to ensure food safety is much needed.

c. Feed Quality: Ethiopia is a nascent market for feed and needs to develop strong quality specifications to build trust and establish value proposition among consumers of animal feed. Ensuring feed quality is a commercial imperative and hence a private sector responsibility.

d. Local community development: Helping local communities around feed mills and maize procurement areas, would be a worthwhile investment for the private sector to build long lasting relationships with the communities.

103. II. Actions to increase space for private sector investments: These are market opportunities across the maize value chain and the regulatory and policy reform might help increase private sector participation in the maize value chain.

1. Regulatory and Policy Reform: There are significant functions which primate sector can effectively deliver, however the current regulatory and policy environment prohibits or doesn't promote active private sector engagement. Some of the following functions have opportunities for significant private sector engagement

a. Seed production and distribution:

b. Agricultural mechanization services:

c. Warehousing and storage:

d. Fertilizer production and distribution:

e. Retail input sale

2. Amendment in Existing Regulations: The cereal sector, in general, is heavily regulated owing to food security concerns and there is heavy state engagement across the value chain. Some regulatory and policy areas which might require rethinking to improve the enabling environment for more private sector engagement include:

a. SoE reform: SoEs are engaged in seed production and distribution, fertilizer importation, agricultural machinery importation and assembly, grain trading, which all could be effectively done by the private sector. As the GoE goes through the SoE reform process, it might be helpful to assess where such SoE perform the core public good functions or whether they could be privatized. 
b. Cooperative sector reform: Unions and cooperatives are engaged in multiple functions in the Maize supply chain, however, they are not professionally managed. A better understanding of the functions of cooperatives and their reform to professionalize the management is much needed in Ethiopian context.

c. Export bans: Ethiopia has witnessed frequent export ban of maize which is disruptive for food and feed sector to develop and should be avoided. Strengthen the capacity of responsible ministry for crop forecasting to better forward plan and consult with industry players on supply/demand balances and needs for imports or restrictions on exports. Review export documentation requirements. Enable/sanction some export of feed by processers to be able to generate foreign exchange to purchase imported feed micro-ingredients.

d. Incentive alignment: In many segments, SoE/Union/Cooperative and private sector are operating simultaneously. However, while the public sector gets significant incentives (in terms of preferential access to capital, grants, land, and machinery) the private sector doesn't get similar incentives. This distorts the competition and doesn't create a level playing field for the private sector, who are new entrants. GoE needs to create level playing fields to foster competition. A thorough review and alignment of incentives is much needed.

3. Public-Private Partnerships: There are a number of areas where PPP arrangements could be developed to facilitate greater private engagement. This could include:

a. Market infrastructure operation and management

b. Warehouse and storage facility operations and management

c. Farmer service centers management

104. III. Actions to improve the policy and regulatory environment for private sector investment and to reduce the distortionary effects of public spending: There are broader enabling environment issues for the agricultural sector and business environment. These are described in detail in the crosscutting issues in Chapter 7.

105. IV. Public investment to reduce private sector transaction costs and risk: Formal private sector engagement is relatively limited in the maize value chain. There are a few segments, especially feed mills for livestock sector and maize processing for human consumption, which have potential for crowding in private sector for investment. The following public investments can reduce transaction costs and risk for private sector:

1. Maize Stakeholder Forum: To facilitate dialogue and coordination of public and private sector stakeholders across the value chain.

2. Disease and pest surveillance and management system: Especially on new pests (fall army worm) and diseases, a system to reduce production losses and ensure quality maize supply to the private sector is needed.

3. Market infrastructure and linkages: Investments by public sector to help develop market linkages between farmers and buyers can help the private sector to ensure aggregation, quality management, and direct procurement.

4. Good agriculture and Post-Harvest Management: Supporting farmers with good agriculture practices and good post-harvest management practices and facilities will improve quality and reduce risk for the buyers.

106. V. Use public resources to invest in public goods and services: These are actions which are mostly public goods in nature and there are limited commercial incentives for private sector to deliver 
these functions. Nonetheless, effective delivery of these functions is quite important in improving the overall supply chain efficiency.

1. Soil improvement and management: Soil fertility management, especially around acidic and sodic soils.

2. Basic research: Basic research on appropriate maize varieties, disease and drought resilience, and good agronomy practices is largely a public sector function which might require investments in the coming years.

3. Basic infrastructure facilities (water, road, electricity): Requisite basic infrastructure support (water, roads, electricity) in the maize growing areas, around feed mill facilities, is much needed in Ethiopia. This would require public investments.

107. Government, in May 2019, amended some regulations Agricultural mechanization (duty free import of agricultural machinery for a period of five years) and contract farming regulation (currently being drafted) could help increase private investment in the maize value chain. The MFD diagnostics have identified a few other potential actions which could be considered for further discussion and analysis by the government as it pursues the reform agenda in the agricultural sector. 


\section{Cross-Cutting Issues and Recommendations for MFD}

108. Agricultural sector in Ethiopia is quite diverse, comprised of cereal crops (wheat, teff, barley, maize), oil seeds, pulses, coffee, honey, sheep, goats, milk, and beef. The nature and structure of each of commodity is quite divergent. However, despite the diversity, there are many common elements, as far as private sector engagement in agricultural sector is concerned. On one hand, there are two subsectors, namely floriculture and large-scale commercial agriculture where private sector (mostly foreign direct investors) are engaged in all activities and public sector engagement is relatively limited. But on the other hand, for most of the agricultural sector, formal private engagement is relatively limited. This final chapter describes major cross-cutting issues that span multiple value chains in the agricultural sector. Several issues that constrain the level of private sector investment are common across the three VCs. This chapter concludes with recommendations for MFD in the broader agricultural sector in Ethiopia.

\subsection{Cross-Cutting Issues}

109. Research and Development: Currently, there is limited private sector engagement in research and development space in agricultural sector. Public sector is engaged in the provision of research and development primarily through national and regional research institutions and universities. Even in the supply chains where the formal private sector is engaged in procurement activities, there is limited backward integration to support good agricultural practices.

110. Input: Similarly, on the agricultural input side, from production to distribution, the space is largely dominated by public sector and majority of the inputs are provided by State-owned Enterprises, Unions, or the line departments of Ministry of Agriculture and aligned ministries. Private sector is more engaged in accessory supplies (packing material, simple equipment, tools, fuel, and office supplies). However, they have limited presence in the production and distribution of core agricultural inputs.

111. Production: Agricultural production is dominated by smallholder farmers in Ethiopia. Yet, their ability to make sizable financial investments in agricultural plots is relatively limited, due to land tenure systems coupled with limited access to finance. Over the past decade, large tracks of land have been allocated to big domestic firms and foreign investors to undertake large scale commercial agriculture, but the experience has been mixed. In certain sectors, such as sugar, cotton, and seed production, SoEs undertake commercial agriculture on large tracts of land.

112. Processing: The processing segment is largely dominated by informal micro-enterprises. While in some segments, especially grains (wheat, maize, teff), coffee, and oilseeds, there are some larger formal sector processing enterprises, but on the broader scale, informal enterprises dominate the landscape of the processing segment. Upgradation and modernization of processing facilities could significantly improve the performance of the value chain. These require significant investment, however, access to finance is one of the major limitations to investment.

113. Marketing and distribution: The organized retail segment is still in its infant stage in Ethiopia. Unorganized micro-enterprises dominate marketing and distribution of agricultural produce in rural and urban areas. The organized sector is growing slowly, especially in Addis Ababa and other major expanding towns, however, market share is relatively limited. More formal sector engagement in marketing and distribution is important to facilitate responsible agricultural investment principals and investments for direct procurement between farmers and consumers. 
114. As indicated in the analysis of beef, maize, and coffee, there are a number of cross-cutting issues across the agricultural sector which need to be addressed to increase private investment in the sector.

\section{Private sector activity across the functions of the VC (RAI)}

115. There are avoidance practices that are not conducive to a healthy private sector operating environment. For example, there are reports of paying bribes for favorable decisions (securing licenses, permits and incentivizing sales), and cases where financial obligations to suppliers have not been honored through either non-payment or the issue of fraudulent checks.

116. There were examples of political lobbying by some actors to protect their vested business interests against increased competition, especially if this involved foreign investors who were introducing more competitive products.

117. Many seemingly find it difficult to grow at scale within a single VC function. The growth strategy is to broaden the business footprint across several VC functions to control raw material supply, processing, and/or market access. For example, a small-scale coffee roaster will open a coffee shop to gain access to the retail market and do roasting in the back section of the shop. A feedlot owner, when scale increases, will open a small slaughterhouse, then a butchery, and eventually a delicatessen.

\section{'Space' for private investors to operate}

118. A raw material supply that underpins private sector investment in processing and marketing relies on the output from millions of smallholder farmers. If they are not successful in producing sufficient surpluses to meet household needs, then the processing and manufacturing sector will remain constrained. Therefore, strategies to support and stimulate greater levels of primary production with links to markets to incentivize increased production will create a greater level of potential private sector processing and marketing opportunity.

119. Some respondents fear that with a growing population and limited employment opportunities, rural population pressure will cause farmers to produce more subsistence food crops or pursue crop selection choices to optimize cash returns off small parcels of land. This could threaten coffee output and restrict maize available for the feed and food processing sectors. Pastoralists continuing to hold cattle for consumptive and productive use, only selling them when they are old and have served their purpose, while the beef sector is looking for volumes of young animals for fattening.

120. Access to finance and appropriate structured finance products, especially for new business start-ups, at farmer production level and for seasonal trade finance limits private sector activity. Cooperatives are particularly vulnerable as they are often the interface with farmers and need seasonal working capital to buy from farmers. Small informal traders find it particularly difficult to raise working capital. Collateral requirements are anything from two to six times the loan value. For land-based enterprises, this is particularly onerous as land (their main asset) has almost zero collateral value and banks only value improvements on the land for collateral purposes. Moreover, interest rates from commercial banks are prohibitively high.

\section{Land Regulation and Policy}

121. Investors expressed concern that land tenure is not sufficiently secure. A more secure tenure rights and/or redress system in the event of a threat of arbitrary rights alienation will encourage investment in land-based production and enterprise. Since the 1990s, the GoE has made efforts to issue certification of use rights to rural households. A 2004 U.S. Agency for International Development (USAID) study indicated the need for further improvement of the regulatory environment through the 
introduction of cadaster maps and a proper land registry through two pilot programs in 2005-2008 and 2008-2013 in selected woredas (districts). With funding support from the World Bank, Finland, Sweden, and the United Kingdom, the GoE implemented a US\$150 million expanded certification to millions of farmers.

122. A USAID study indicated land certification led to a 10 percent increase in the likelihood of accessing credit, an 11 percent increase in landholding, a 44 percent increase in women's decision making over crops, and an 11 percent increase in the likelihood of households believing they have the right to bequeath land to their heirs. Another study (Bezu and Holden 2014) found that demand for second stage certification (mapping and registration) was low as farmers did not believe it would improve tenure security above what they enjoyed in the first stage certification.

123. The USAID evaluation recommended further legal reforms to allow land to be used as collateral to enable increased credit access. The GoE has reportedly embarked on pilot projects with United Kingdom funding to test mortgaging land use rights with a view to develop the requisite legal framework. The outcome of these pilots and the reform of the legal framework could be significant for the private investor.

124. Private investor respondents reported that it was not yet possible for them to collateralize land, which weakens the enterprise balance sheet and ability to access development finance. This slows down the pace of development and economic activity, including job creation capacity. Additionally, women historically face challenges of accessing land. There is reference to pilot projects being undertaken by the GoE to test mortgaging of land to develop the necessary legal framework, but the progress is not clear.

\section{Foreign exchange}

125. Export commodities are used as foreign exchange proxies. Exporters are prepared to buy an exportable locally produced commodity at an inflated price, then sell on export markets at a loss and make up the loss through the profit on the imported goods financed through the exported commodity. Respondents indicate a margin of 20-35 percent loss is accepted but made up on imports. This margin is in a way a shadow pricing of the real exchange rate. The effect is a potentially reduced foreign exchange revenue with local consumers subsidizing the loss and indirectly the international buyers of the traded commodities who are getting the products at a discount. While the National Bank has issued a directive to the commercial banks to put a stop to this practice, some are still able to circumvent the directive.

126. Circumvention of foreign exchange regulation needs to be addressed. In the coffee and live animal export sectors, it is reported that some exporters are merely using trade in exportable commodities to generate foreign exchange to finance their imports. They accept losses on exports rather than hold out for fair to good benchmark prices, simply to generate foreign exchange. They then circumvent National Bank regulations to use the foreign exchange generated to finance imports, where the profit made offsets the losses on the sale of the commodity. This practice negatively affects international pricing perceptions of Ethiopian beef and coffee.

\section{Entrepreneurship and business development}

127. In the Ethiopian agricultural sector, the market is dominated by informal micro-enterprises across the value chain. At the market end, there are few large formal enterprises that are engaged in processing, export, and retail sales. There is a big void of small and medium businesses in the enterprise spectrum. In most countries, the spectrum from micro, small, medium to large enterprises, creates role models and desire for growth. This trajectory of growth spurs innovation and investment fueled by entrepreneurial drive. This is currently missing and limits opportunities of growth for micro and informal enterprises. In addition, the command economy of the past five decades has curbed 
private enterprise and entrepreneurship. The ecosystem to support entrepreneurship and innovation is quite nascent in Ethiopia. It needs to be nurtured to create local entrepreneurs who could establish enterprises and jobs in agricultural value chains.

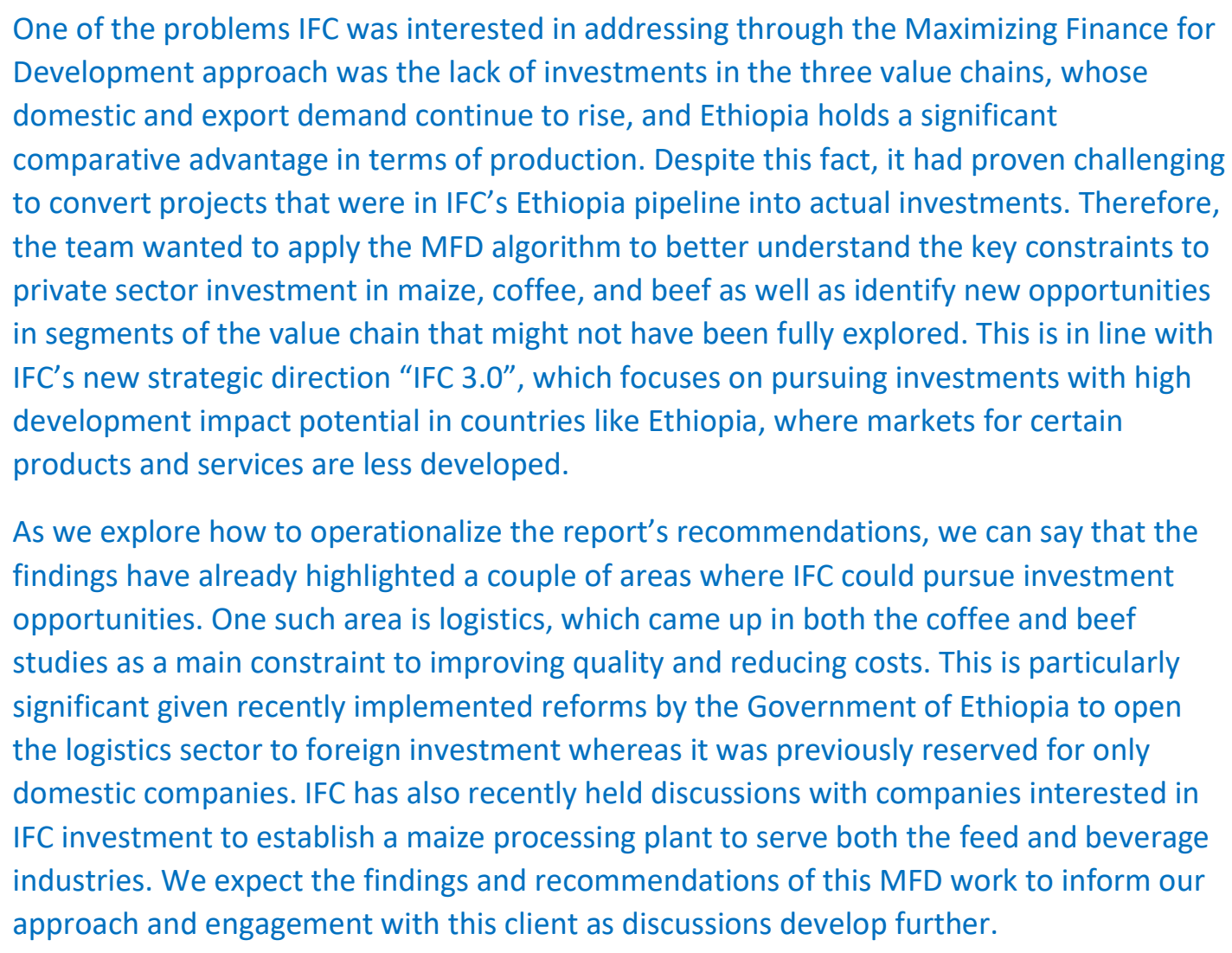

\section{Taxation}

128. Taxation compliance procedures need to be reviewed. Ministry proclamations on regulatory elements need to align with the Ethiopian Revenue and Customs Authority (ERCA) tax directives. For example, pastoralists are not registered as traders. Therefore, butcheries and feedlots that buy directly from pastoralists have their purchases questioned as not being eligible expenses for taxation purpose. Yet, if the butchery buys from livestock traders, the purchases are seen as allowable expenses for taxation purpose. Moreover, livestock traders are able to purchase directly from the same pastoralists without ERCA questions. Even when the butchery followed ERCA procedures by having copies of the pastoralists identity document (ID) and a purchase order, they were still questioned by ERCA for proof from the butchery that the pastoralist they purchased from was in fact a pastoralist. This creates disincentives for developing direct procurement relationships between pastoralist and processors/exporters.

129. Tax directives and the application thereof by tax officials are not always aligned to subsector proclamations. As example when it comes to processors procuring from smallholder farmers, who are not formally registered as traders. This results in unnecessary tax audits. Alternative methods of incentivizing tax compliance rather than criminalizing instances of unintended noncompliance should be considered.

130. Access to finance: Limited agricultural finance is one the biggest challenges for private sector investment in the agricultural sector. Only $12 \%$ of total loan disbursement by commercial banks in 
2017 in Ethiopia was classified as loan to the agricultural sector. Majority of these loans were provided to large scale commercial farmers, coffee and sesame exporters, and cooperative unions. MFIs and Savings and Credit Cooperatives (SACCOs) do provide some financing in rural areas, but the average loan value is much smaller and not appropriate for the requirement of the agricultural sector. Private sector, across the value chain, needs access to finance to effectively function and upgrade their operations, and unless the bigger financial sector, and specifically agricultural finance, issues are addressed, there will be limited liquidity and hence limited investment by the private sector in agriculture. While addressing the overall financial sector issues, specific financial products that meet the requirements of the agricultural sector need to be designed and delivered.

131. Aligning incentive system between SOE, Union/Cooperative, and Private Sector: In some areas, especially input, there is "unfair" competition between State-owned Enterprises, Union/cooperatives and private sector. While the state supported enterprises get preferential treatment, (eg. access to credit, access to land, subsidized infrastructure facilities and machineries), private sector does not get similar support. This creates an uneven playing field between private sector and public sector. This limits competition and does not create incentive for private sector to make investments in such activities. Interventions are needed to align the incentive systems to foster fair competition and drive innovation and upgradation in many activities in the agricultural supply chain.

132. Regional alignment of regulations: Ethiopia has a federal structure which provides flexibility for the regions to adapt and develop rules and regulations that respond to the local context of the regions. While the policy directions are set up by the federal government, in most cases, regulations are often determined by regional governments. This creates significant challenges for private sector since there are significant variations in regulations between different regions. While some regions have a more relaxed land tenure regulation to promote land rental markets, other regions have more restrictive regulations to inhibit land rental market. In some cases, the regional regulation might be contrary to the national policy and prohibit development of national markets for goods and services in agricultural sector. Harmonization between regulations across regions and their alignment with national policies and regulations will help improve the enabling environment for private sector engagement in agricultural sector.

133. Business environment: The overall business environment in Ethiopia needs significant improvement which have been indicated in the Country Private Sector Diagnostics. Agribusiness works within the broader business environment of the country and improving the overall business environment will have significant impact on the agribusinesses. To sustain Ethiopia's development path, key reforms in strategic sectors, such as telecommunications, energy, and logistics, are critical to enhance competition, improve efficiencies, and move to a more sustainable model of infrastructure financing. Improving macro-economic stability and sector specific reform actions are needed.

\subsection{Conclusions and way forward for MFD}

134. There are many challenges across the beef, coffee, and maize subsectors, some sector specific and some cross-cutting. These challenges relate either to the history of the subsector and policy environment or are a consequence of market conditions.

135. Applying the MFD diagnostic has identified a wide-ranging set of options that can be considered for improving the investment environment for enhanced private sector participation, 
some require private sector action, others policy amendments, and the design and implementation of supporting programs.

136. It is recommended that local ownership of the process to review policies and develop programs vest with both the GoE and private sector actors. A means of bringing the parties together to find solutions could be through constituting a commodity-specific subsector forum where actors from across the VC can raise concerns, propose, agree on solutions, and monitor the effectiveness of implemented recommendations.

137. Actors will need to engage and agree on the priority to address the suite of identified functions that private sector could be doing but is not, or where it is weakly represented. Additionally, the range of opportunities identified in the report that could further incentivize private sector investment should also be discussed and prioritized and a program of action agreed upon on how best the concept could be further developed into a program of action.

138. Private sector bodies should consider the development of codes of ethical business practice and introduce a system of promoting their application, which could consist of a combination of educational and capacity building initiatives and possibly appropriate censure of non-compliant members.

139. The study identifies 10 activities in the beef VC, 9 in the coffee VC, and 10 in the maize VC where the private sector is crowded out by state activities and restricted by policy. GoE should continually review the effectiveness of state interventions in the market and/or the functions of their ministries and SoEs (which can be done through benchmarking of activities against accepted private sector performance parameters). The effectiveness of cooperatives should also be assessed with the view to transforming them to be more commercially focused and professionally managed. It is recommended that the GoE should proactively review and revise policy and regulations that unduly restrict or limit private sector. Regulations need to be applied fairly and uniformly to discourage illegal practices and corruptive circumvention strategies that, in turn, compromise good business practice.

140. A suite of financial products that are accessible, reduce risk, and appropriate to the enterprise or activity being financed is also required. Purely public finance issues relate directly to the need for improving infrastructure, telecommunication coverage, and investment in skills development. Public investment support to design and implement intervention programs will also be required.

141. The WBG can play several roles in facilitating and promoting a greater level of private sector investment. The World Bank plans to further promote the outcomes of this MFD diagnostic during presentations to stakeholders, implementation of technical assistance program for agricultural policy and regulatory reform, one-on-one stakeholder engagements, establishment of a blogpost for generating further ideas on the subject, and an agricultural sector deep dive Country Private Sector Diagnostic study planned for 2020. In turn, the IFC has during the process of this study already identified several areas for potential private sector investment to be able to respond to approaches from the business sec 


\section{References}

Asfaw, F. (undated). Setting Up a New Business in Ethiopia. Fikadu Asfaw and Associates Law Office. https://www.hg.org/legal-articles/setting-up-a-new-business-in-ethiopia-19590.

Esubalew, A., and A. Raghurama. 2017. "Micro, Small and Medium Enterprises (MSMEs) Development Strategies in Ethiopia: Retrospective and Prospective Analysis." IRACST-International Journal of Commerce, Business and Management 6 (1).

Ismail, Z. 2018. Privatisation of State-Owned Enterprises in Ethiopia since 1991. University of Birmingham.

World Bank. 2017. Enabling the Business of Agriculture 2017. World Bank Group.

-- - 2018a. Doing Business 2019: Economy Profile Ethiopia. World Bank Group Flagship Report, 16th Edition. Comparing Business Regulations for Domestic Firms in 190 Economies.

-- - 2018b. Country Private Sector Diagnostic. World Bank Group.

Cheorun, S., Jo, C., Lee, M. 2014. "Meat Consumption Culture in Ethiopia." Korean Journal of Food Science of Animal resources and Technology.

Delgado, C., Rosegrant, and Meijer. 2001. Livestock to 2020: The Revolution Continues.

MoLF (Ministry of Livestock and Fisheries). 2017. Study to Assess the Feasibility of Public-Private Partnerships for Selected Livestock Facilities/Service Areas in Ethiopia. Feed the Future. USAID.

Semeneh. 2014. Livestock Master Plan: Road Map for Growth and Transformation. Ministry of Agriculture.

Shapiro, B. I., G. Gebru, S. Desta, A. Negassa, K. Nigussie, G. Aboset, and H. Mechale. 2017). Ethiopian Livestock Sector Analysis. Ethiopia Ministry of Livestock and Fisheries and the International Livestock Research Institute. Bill and Melinda Gates Foundation.

Towers, L. 2016. Opportunities and Challenges for the Sub-Saharan African Meat Market. The Fish Site. https://thefishsite.com/articles/opportunities-and-challenges-for-the-subsaharan-africa-meat-

market.

Beshah, B., and D. Kitaw. 2013. Quality and Value Chain Analysis of Ethiopian Coffee.

Debelo, B. K. 2017. Constraints and Opportunities in the Coffee Supply Chain: Value Chain Analysis from Coffee Farmers to Exporters - Case of Some Selected Districts of Ilu Aba Bor Administrative Zone, Oromia, Ethiopia.

Duguma, T. F. 2017. Value Chain Analysis of Ethiopian Coffee (Coffea arabica).

Fekadu, T. 2018. Value Chain Analysis of the Pre-and Post-harvest Factors Deteriorating The Quality Coffee in the Chole District, Oromia Region, Ethiopia.

Kufa, T. 2015. "An Overview of Coffee Research in Ethiopia." IFPRI and EDRI Organized Conference on "Ethiopia's Coffee Value Chain: Evidence towards Improved Investment and Policies," Addis Ababa, September 15.

Kufa, T., et al. 2011. Challenges and Opportunities of the Coffee Seed System of Ethiopia.

Kuma, T. 2018. Ethiopian Coffee Value Chain: Prospects and Challenges. International Coffee Event in Ethiopia. Addis Ababa, December 4-5, 2018. 
Minten, B., S. Tamru, et al. 2014. Structure and Performance of Ethiopia's Coffee Export Sector. IFPRI. - - - 2015. Coffee Value Chains on the Move: Evidence from Smallholder Coffee Farmers in Ethiopia. IFPRI.

Poor Farmer: Coffee Politics. 2009. "ECX and its Effect on the Coffee Sector." Poor Farmer: Coffee Politics (blog), August 3. http://poorfarmer.blogspot.com/2009/08/ecx-and-its-effect-on-coffeesector.html.

Szenthe, A. 2018. https://www.worldatlas.com/articles/top-coffee-producing-countries.html. World Atlas.

Tamru, T., and B. Minten. 2015. "Benefits and Challenges for Wet Mill Use in the Coffee Sector." IFPRI and EDRI Organized Conference on "Ethiopia's Coffee Value Chain: Evidence towards Improved Investment and Policies," Addis Ababa, September 15.

-- - 2016. Value Addition and Processing by Farmers in Developing Countries: Evidence from the Coffee Sector in Ethiopia.

USDA Foreign Agricultural Service. 2013. Coffee Annual Report.

USAID (U.S. Agency for International Development). 2010. Ethiopian Coffee Industry Value Chain Analysis: East Africa Trade Hub.

Wolde, Z. 2017. A Review on Coffee Farming, Production Potential and Constraints in Gedeo Zone, Southern Ethiopia.

ATA. 2013. Maize Sector Development Strategy: Working Document 2013-2017, Addis Ababa, Ethiopia.

---. 2016. Greening of the Maize Value Chain in Ethiopia: Volume I - Background and Findings. Addis Ababa, Ethiopia.

EEA. 2017. Research Brief: Issue No. 02. Addis Ababa, Ethiopia.

EIAR. 2014. Situation and Outlook of Maize in Ethiopia. Addis Ababa, Ethiopia.

IFRI. 2010. Maize Value Chain Potential in Ethiopia: Constraints and Opportunities for Enhancing the System. Washington, DC.

-- - 2015. Maize Value Chain in Ethiopia: Structure, Conduct and Performance. Washington, DC.

USAID Feed the Future Ethiopia Value Chain Activity. 2017. Value Chain Analysis: Maize Partnering with the Agricultural Growth Program. Addis Ababa, Ethiopia.

World Bank. 2018. Cereal Market Performance in Ethiopia: Policy Implications for Improving Investments in Maize and Wheat Value Chains. Agriculture Global Practice GFA13: Washington, DC. 


\section{Annex}

\subsection{Annex 1: The MFD Methodology}

\subsubsection{Background}

The food and agriculture-related United Nations agencies estimate that ending poverty and hunger requires additional financing of US\$140 billion per year in agriculture and rural development. Of this US\$140 billion, US\$50 billion per year is needed from the private sector, primarily in on-farm and agroprocessing investments and US\$90 billion per year is needed from the public sector for public goods such as agricultural research and rural infrastructure of a public nature that is economically justified. ${ }^{4}$ Achieving development goals beyond ending poverty and hunger would require even more additional financing.

Crowding in private investment to help achieve these goals and optimizing the use of scarce public resources will be needed, as will the continued promotion of good governance and environmental and social sustainability.

\subsubsection{MFD approach}

The MFD approach supports client countries to maximize their development resources by drawing on private financing and sustainable private sector solutions to provide value for money and meet the highest environmental, social, and fiscal responsibility standards and reserve scarce public financing for those areas where private sector engagement is not optimal or available. Increasing private sector investment and associated financing in the agriculture and food VC will require identifying and understanding market failures currently leading to the suboptimal private provision of goods and services needed to achieve key development goals.

Therefore, the approach has two aspects:

(a) Identify the area where public money is most needed and can realize the most significant impacts.

(b) Enable the private sector to invest in the remaining areas.

\subsubsection{Applying the MFD approach in the agriculture and food sector ${ }^{5}$}

The characteristics of the agriculture and food sector should be considered when applying the MFD approach in the sector.

- The agriculture and food sector is not stand-alone but dependent on other sectors, including water, energy, infrastructure, transportation, and ICT. Therefore, commercialized agricultural development planning requires full competitive access to the services provided by these sectors.

- The agriculture and food sector is connected through VCs (Figure 4). In many countries and subsectors, the chain is long (even import dependent), disjointed, and inefficient, with many different stakeholders.

\footnotetext{
${ }^{4}$ FAO, IFAD, and WFP. 2015. Achieving Zero Hunger: The Critical Role of Investments in Social Protection and Agriculture. Rome, FAO.

${ }^{5}$ For more details, see World Bank. 2018. Future of Food: Maximizing Finance for Development in Agricultural Value Chains.
} 
- There are often a limited number of scaled private sector investments that produce, manage logistics, process, and sell covering the whole VC.

- Agriculture production offers seasonal and variable returns. Therefore, cash flow is erratic and makes investment returns risky and hard to achieve.

- Local processing is dependent on an efficient raw material procurement and supply network. Too often, the local supply chain does not meet the demands of the processing units and either the unit runs inefficiently or is dependent on imported raw materials.

Figure 4: Agriculture and Food Value Chain Ecosystem

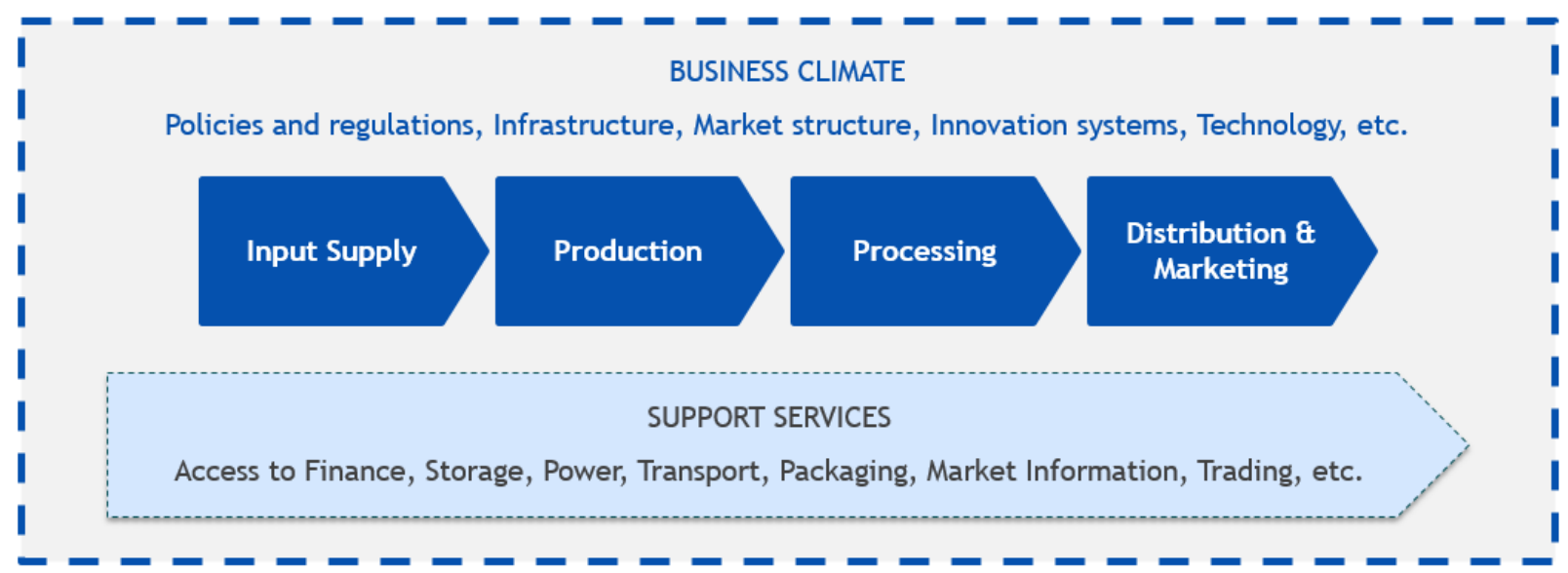

\subsubsection{MFD Actions}

The following are the key actions for applying the approach in the agriculture and food sector:

(a) Diagnostics - Conduct deep-dive analysis on selected VCs in a country and develop concrete recommendations.

(b) Policy reform - Design and implement adequate policy reform.

(c) De-risking agriculture - Identify and mobilize tools, techniques, and partners to develop creative ways to de-risk agriculture across the supply chain segments.

(d) Facilitating multi-stakeholder collaboration - Build multi-ministerial or multisector platforms to create direct collaboration and partnerships.

\subsubsection{MFD value chain diagnostic: The first step}

The MFD value chain diagnostic is expected to answer the following key questions:

(a) What are the areas where the private sector is currently engaged? How can the size of investment be increased while ensuring social and environmental responsibility?

(b) What are the areas where the private sector is currently engaged BUT competing with the public sector? How can the situation be resolved?

(c) What are the areas where the private sector is currently NOT engaged? Why?

The purpose of the diagnostic is to identify constraints, opportunities, and solutions for leveraging private sector engagement in the given VC. Since any given value chain has multiple components (Figure 4), engages with various activities, and involves many actors, this diagnostic requires combing 
through the entire ecosystem that would bring a large number of constraints and opportunities to the fore. The wealth of the information contributes to the development of holistic solutions.

To conduct the diagnostic for any given VC, the suggested steps are the following:

Step 1: Develop a sector overview.

Step 2: Conduct an institutional mapping and identify activities along VC components.

Step 3: Interview key stakeholders, including the private sector.

Step 4: Identify issues, solutions, and actions and map them on the matrix based on the 'cascade questions' for each VC component.

Step 5: Prioritize actions.

\subsubsection{Cascade questions for the diagnostic}

To systemically, comprehensively, and logically conduct the analysis, the World Bank Group developed a set of cascaded questions. ${ }^{6}$

1. Is the private sector doing the activity? If yes, how can investments be increased and how can it be ensured that they are socially and environmentally responsible?

2. If not, is this because the public sector is crowding out the private sector? If that is the case, how can the space for the private sector be increased?

3. If not, is this because of policy and regulatory gaps or weakness? If that is the case, what are these gaps and what opportunities for solutions are there?

4. If not, is it too risky for commercial business but public investment inducement can help to mitigate the risk and or improve returns to be acceptable for private investment?

5. If not, then it is a purely public sector activity.

For each cascaded question, examples of solutions are described in Figure 5.

${ }^{6}$ World Bank. 2018. Future of Food: Maximizing Finance for Development in Agricultural Value Chains. 
Can private sector do it/ls private sector doing it?

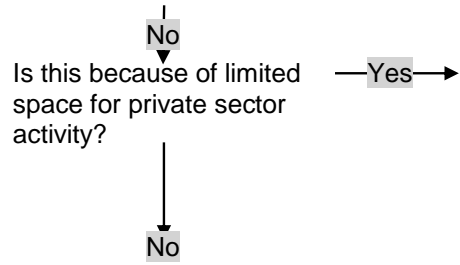

Is this because of policy and regulatory gaps or weaknesses?

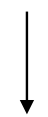

No

Can public investment help crowd in private investment?

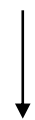

No

Pursue purely public financing

Spectrum of actions to ensure responsible agriculture investments

- Strengthen country capacity to assess and mitigate/regulate for environmental and social risks

- Support country and firm approaches to operationalizing RAI principles

- Promote sustainable financing of agriculture/agroindustry further upstream towards smaller farmers and agribusiness SMEs, by leveraging public sector policies and financial support to crowd in the private sector financial institutions

- Promote financial solutions for investment in climate smart agriculture and agribusiness

Spectrum of actions to increase space for private sector activity e.g.

- Support to competition assessment, policy and reform (e.g. of SOE)

- Support to Investment Policy reform and dialogue

- Political risk insurance for financial institutions and private investors

- Support active and effective public-private dialogue (PPD) mechanisms

Spectrum of actions to improve the policy and regulatory environment for private sector, investments, reduce compliance costs and minimize the distortionary effects of public spending e.g.

- Yes $\longrightarrow$ It is important to promote the reduction or

removal of subsidies

- Globally $\$ 210$ bn in direct annual budgetary payments (subsidies) provided to producers 2013 15

- \$375bn take form of price supports that keep domestic prices above world prices (based on estimates of 50 countries provided by OECD 2016).

To raise private sector returns

- Support private sector oriented diagnostics on priority gaps

- Reduce implicit and explicit ag. taxation

- Reduce import tariffs and export restrictions

- Improve regulatory policies and regulations around input and output markets

- Support risk based inspections and reduce compliance costs all along value chain

- Reform internal and border trade logistics for safe and streamlined trade in agri products

To reduce private sector risk

- Reduce inconsistency in policy

- Improve tenure security

- Strengthen water rights \& pricing policy

- Enable regulations and promote institutional arrangements that would facilitate the use of risk management tools (credit bureaus, collateral registries, credit guarantees, insurance, hedges)

- Support regulation for better access to professional storage (e.g. WRS legal and regulatory reform)

- Reform to food safety systems and policies

- Improve the Agrifinance market: focusing on enabling government policies and regulatory

\begin{tabular}{ll} 
Spectrum of public investments to induce more private sector investments & e.g. \\
\hline To raise private sector returns & To reduce private sector risk \\
- Comprehensive agribusiness diagnostics focused & $\bullet$ Cost and risk-sharing instruments to of \\
on private sector prioritization of constraints and & set risks and start-up costs (e.g. credit \\
opportunities & guarantees, first loss guarantees, \\
- Invest in public infrastructure (roads, irrigation, & matching grants) \\
energy, ICT, special economic zones (e.g. agri & - Risk transfer mechanisms (derivatives, \\
parks) based on private sector demand) & insurance, stop loss agreements) \\
- Improve co-ordination to reduce transaction costs & \\
(support for producer organizations/productive & \\
alliances, improved market information systems, & \\
promotion of technology based solutions for & \\
marketing commodities, and where appropriate & \\
development of agriculture commodity exchanges, &
\end{tabular}

Invest in public goods or semi-public goods

- Participate in the reduction of subsidies debate

- Where there is no viable private sector return invest in productive public owned assets (such as roads, energy, water \& ICT) to enable the commercialization and competivenes of national agricultural production, processing and marketing 


\title{
9.3 Annex 2: Beef Value Chain Description
}

\author{
Contribution to the economy - Subsector overview
}

Ethiopia is known for its large livestock population of about 55.2 million head, as well as its diverse agroecology suitable for a wide range of livestock species. The direct contribution of livestock (including all livestock plus processing and marketing) to GDP is estimated, in 2013, at ETB 186.3 billion per year, or 21 percent of GDP and 49 percent of the agricultural GDP (Shapiro, Getachew, et al. 2017). This percentage is likely to increase in the coming decades, with the sector remaining a significant contributor to the gross value of agricultural products. Of the ETB 186.3 billion GDP contribution, beef accounts for ETB 43.4 billion (23 percent), which excludes hides and skins. The value addition component is an additional 19 percent of the primary production contribution, compared to 100 percent and above for some neighboring OECD countries. This indicates an underdeveloped or partly unrecorded sector. In Ethiopia, there is reportedly a high level of backyard, informal slaughtering.

Despite available resources and conducive factors for livestock development, consumption of animal based-food like meat and milk is one of the lowest among the Sub-Saharan African countries. Per capita meat consumption for Ethiopia is estimated to be $8.5 \mathrm{~kg}$ (Sileshi et al. 2014) compared to about $22.6 \mathrm{~kg}$ per capita measured over 43 Sub-Saharan markets (Towers 2016).

As the level and distribution of income increases, there is a tendency to consume relatively more livestock products. Likewise, urbanization and the consequent improvement in infrastructure encourage diet diversity, with a shift toward livestock products and nutritious food leading to further demand for meat. Supplying the ever-increasing demand and satisfying consumers will be difficult if there is no livestock revolution (Delgado et al. 2001).

\section{Institutional Mapping}

An institutional mapping of the GoE actors and functions across the VC and the level of intervention by government in the sector is illustrated in Figure 6 . The mapping shows the State institutions that provide a range of support and/or regulatory services across the VC.

Figure 6: Institutional Mapping of State Function Across the Beef VC

\begin{tabular}{|c|c|c|c|c|c|}
\hline Organization & $\begin{array}{l}\text { Research \& } \\
\text { Development }\end{array}$ & Input Supply & Production & Processing & $\begin{array}{l}\text { Distribution \& } \\
\text { Marketing }\end{array}$ \\
\hline Ministry of Agriculture & $\begin{array}{l}\text { - Provides policy } \\
\text { environment, formulate } \\
\text { strategies and lead the } \\
\text { extension service }\end{array}$ & & & $\begin{array}{l}\text { - Provides inspection } \\
\text { service, Certify abattoirs }\end{array}$ & $\begin{array}{l}\text { - Assist in market search } \\
\text { and market linkage } \\
\text { - Quarrantine services for } \\
\text { export }\end{array}$ \\
\hline $\begin{array}{l}\text { Ethiopian Institute of } \\
\text { Agricultural Research }\end{array}$ & - Generate technologies & - Disseminate technologies & & & \\
\hline $\begin{array}{l}\text { Ethiopian Meat and } \\
\text { Dairy } \\
\text { Technology Institute }\end{array}$ & & & $\begin{array}{l}\text { - Provides short term and } \\
\text { tailored trainings to the private } \\
\text { sector, assist in land acquisition } \\
\text { etc. }\end{array}$ & & $\begin{array}{l}\text { - Assist in market search } \\
\text { and market linkage }\end{array}$ \\
\hline $\begin{array}{l}\text { National Institute of } \\
\text { Animal breeding }\end{array}$ & $\begin{array}{l}\text { - Implement breeding } \\
\text { policies }\end{array}$ & $\begin{array}{l}\text { - Import, produce and } \\
\text { distribute semen }\end{array}$ & $\begin{array}{l}\text { - Manages stud bull producing } \\
\text { herd } \\
\text { (Mainly for dairy) }\end{array}$ & & \\
\hline $\begin{array}{l}\text { Ethiopian Veterinary } \\
\text { Drug and Feed } \\
\text { Regulatory Agency }\end{array}$ & & $\begin{array}{l}\text { - Certify feed processing } \\
\text { industries } \\
\text { - Provide laboratory services }\end{array}$ & $\begin{array}{l}\text { - Ensures quality and safety of } \\
\text { feed and drug in use }\end{array}$ & & \\
\hline $\begin{array}{l}\text { National Veterinary } \\
\text { Institute }\end{array}$ & & $\begin{array}{l}\text { - Produce and disseminate } \\
\text { vaccines }\end{array}$ & & & \\
\hline ATA & \multicolumn{4}{|c|}{ - Identify systemic bottlenecks and recommend solutions (Capacity gaps) } & - Market info and linkages \\
\hline
\end{tabular}

Ministry of Agriculture: The MoA has several affiliated institutions: (a) the NVI, commissioned to produce vaccines and drugs; (b) the NAHDIC, mandated to improve productivity of animals and provide advisory services to livestock keepers; (c) the National Animal Breeding Institute (NABI); d) 
the Ethiopian Veterinary Drug and Feed Regulatory Authority (EDFRA); and (e) current agricultural marketing support services. The unit is mandated to develop strategic solutions to marketing challenges faced by livestock traders.

The MoA, with the support of donors, assists producers and processors in gaining access to international markets. It facilitates attendance at international food fairs, notably the annual Gulffood Fair. The government, in most cases, pays for a booth and supports promotional activities. Apart from providing the above-mentioned services, the MoA leads policy drafting and the development of regulations pertaining to livestock.

Ethiopian Meat and Dairy Industry Development Institute: The EMDIDI, which reports to the Ministry of Trade and Investment, has the mission of making Ethiopian commercial livestock and livestock products competitive, in the domestic as well as the international market, through investment facilitation. It provides tailored hands-on training to feedlot operators and abattoir personnel.

Ethiopian Institute of Agricultural Research and Regional Research Institutes: The EIAR, as well as regional research institutes, has the mission of developing and testing technologies to enhance productivity of animals. Apart from conducting cutting-edge research, the EIAR has a federal mandate to oversee research undertakings of regional research institutes, to bring harmony and avoid duplication of efforts. With respect to beef production, the institute has evaluated various crossbred animals, to determine appropriate, exotic breeds suitable for different agroecology. Further, it has undertaken characterization of several breeds/types of cattle, notably Arsi, Borena, Horo, Fogera, and Raya cattle. A recent agenda of research centers is the development of feeding management strategies to accelerate weight gain of local breeds to attain the target of 300-350 kg live weight in less than three years. Breeds that have such potential have been identified.

\section{Input suppliers}

\section{The feed industries}

Large-scale feed processing plants producing concentrate/compound feed are located in and around Addis Ababa. Cooperative and small-scale feed processing plants are scattered across the country, but their number is limited. A common feature of feed processing plants is the focus on poultry and dairy feed, primarily dictated by demand.

Feedlot operators depend on their own mix of feed made from purchased or own-grown feed ingredients. Small-scale operators in the rural areas rely on home-grown feed with the use of oilseed cake in the final stage of the fattening period, usually about two weeks before selling the animals.

\section{Veterinary services}

Currently, veterinary services such as disease surveillance, clinics, meat inspection, vaccine production and distribution, and drugs are mainly provided by the government. Few veterinary drug shops and private clinics are available in major cattle-producing areas. On the contrary, illegal drugs are sold in the open market, especially in pastoral areas. In most cases, these drugs are improperly handled and may have expired. Producers purchase them without prescription and this may result in over/under dosage of the animals. Studies have shown that in pastoral areas some ticks have developed resistance to acaricides and this is attributed to drug abuse.

\section{Slaughter services}

Apart from the export abattoirs, there are 296 municipal abattoirs in Ethiopia. This number is projected to increase to 616 by 2020 (MoLF 2017). There are a few private slaughterhouses in Addis Ababa and Modjo that slaughter and distribute carcasses to butcheries.

Public-owned abattoirs are poorly equipped and lack cold rooms, implying that carcasses need to be distributed immediately after dressing. Even the Addis Ababa abattoir, which slaughters over a 
thousand cattle per day and distributes them to many of the local butcheries, does not have a refrigerated truck for distribution of carcasses. This practice is a major public health concern.

\section{Transporters}

Animals are transported from primary market to final market on ISUZU/FSR trucks. Dedicated livestock transport services, particularly for cattle, are nonexistent in Ethiopia. There is an animal welfare issue related to this. Furthermore, the quality of meat or carcasses from improper handling of animals during transportation can be significantly reduced. The situation is improving for small ruminants Recently, dedicated vehicles with the capacity to transport 1,000 sheep and goats were imported. On the other hand, export abattoirs have refrigerated trucks transporting frozen carcasses from the abattoir to the airport.

\section{Sectoral associations}

There are five sectoral associations: the Ethiopian Meat Processing and Exporters Association, Ethiopian Live Animal Exporters Association, Ethiopian Livestock Trader Association, Ethiopian Slaughter Animal Suppliers Association, and Ethiopian Domestic Abattoir and Butchers Association. These associations are meant to defend the rights of tier members and advocate the cause of the members. They also liaise with the tax revenue authority when issues related to taxes are raised.

\section{Cattle ownership}

An estimated 9.48 million households (Shapiro et al. 2017) are comprised of cattle owners. While there is a high level of private sector ownership of the national herd of about 55.2 million cattle, a large proportion of these households are very poor. Somewhere between 27 to 35 percent of the highland livestock owners (where most of the cattle are reportedly held) are below the GoE established poverty line (ibid.).

In the pastoral areas, which occupy the eastern and southern lowlands, cattle provide a means of livelihood and are a source of meat and milk. The pastoral system is exposed to extreme climatic stress which makes it vulnerable. In such environments, risk avoidance is a resilience strategy but this has a direct influence on production efficiency.

Cattle are by far the dominant species in the mixed-crop livestock system of the highland. They play a key role in providing traction power for land cultivation. Meat and milk are considered byproducts of the production system. In the highlands, where the majority of the human population lives, cattle numbers are estimated to be about 80 percent of the total livestock population (about 41 million) and exist in small herds ranging from 2 to 4 cattle. Meat production is secondary to other purposes and involves mainly old (retired draught oxen) and unproductive animals. These animals are usually fattened after retirement and are the source of meat for big cities.

Beef production per animal (kilograms) is variable, dependent on weather patterns outlined in the graph in Panel C (Shapiro et al. 2017). In times of drought, more animals become available and during wet cycles, animals are retained as herds are rebuilt. 


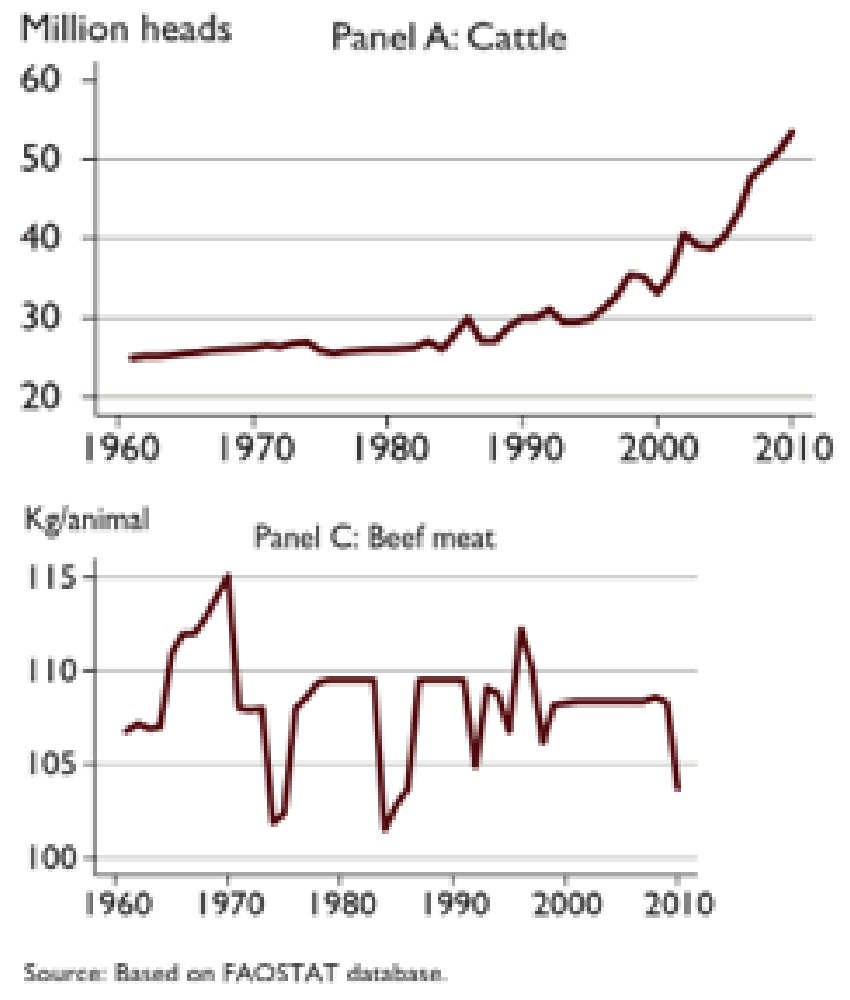

\section{Cattle fattening sector}

Cattle production systems are continually evolving, partly as a response to the opportunities provided by emerging markets. Consequently, small-scale fattening of cattle in feedlots of 4 to 10 units per feedlot, targeting demand during public holidays, are flourishing in many areas. Commercial feedlots with a capacity to fatten 200 to 5,000 head of cattle have been developing over the last 15 years. These feedlots are mainly along the live animal export routes and near logistic corridors.

\section{The dilemma of export versus domestic market for beef}

The pastoral areas are the major source of livestock for the export market. In fact, all feedlots source animals from the lowland pastoral areas where the appropriate cattle type are prevalent. Animals in these pastoral areas are not used for traction purpose and mature early. Additionally, meat from lowland cattle is considered to be more tender.

There is a strong push by the government to increase the number of livestock exported to earn foreign currency. About 60 percent of livestock export earnings come from live animal export. Export demand for Ethiopian beef is still in its nascent state. Many of the export abattoirs are not equipped to slaughter cattle and process beef but rather are more focused on sheep and goats. Not only is the demand limited, but Ethiopian beef meat is reportedly not competitive with alternative suppliers such as Argentina. There is reportedly an increasing trend of importing meat from abroad by large hotels in Addis Ababa. The main reason is due to the poor quality of meat available on the domestic market. Currently, there are about 60 hotels (ranging from 1 to 5 stars) that demand quality meat. The number of big hotels in Addis Ababa and major regional towns demanding quality meat is likely to continue increasing rapidly. This increased demand will result in heightened opportunity for expanding production of quality meat. This requires a paradigm shift to focus also on the domestic market. 


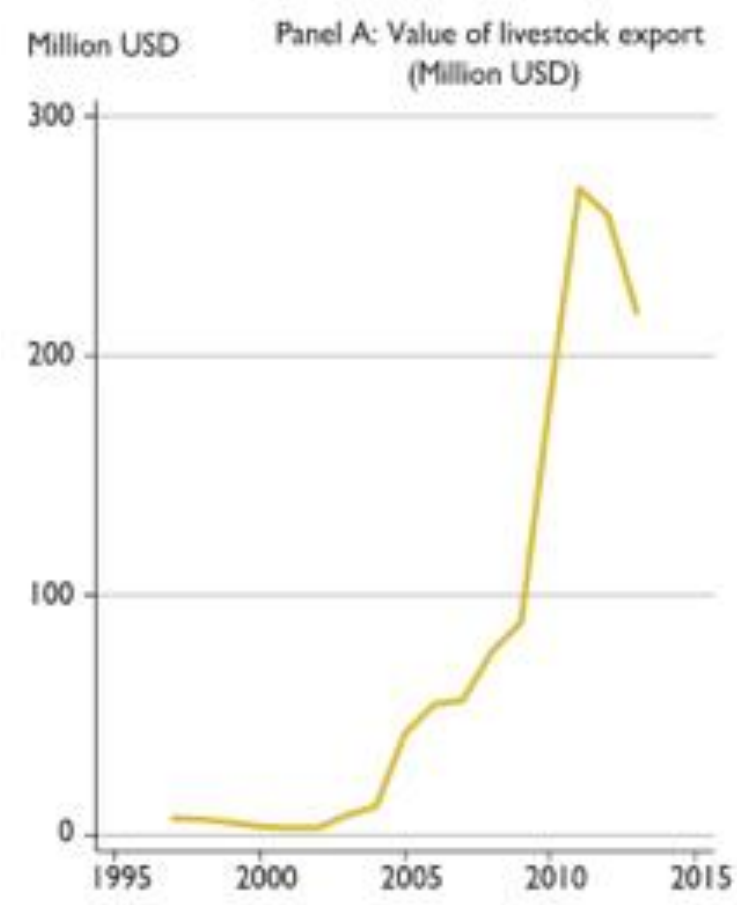

Source: ERCA (2013).

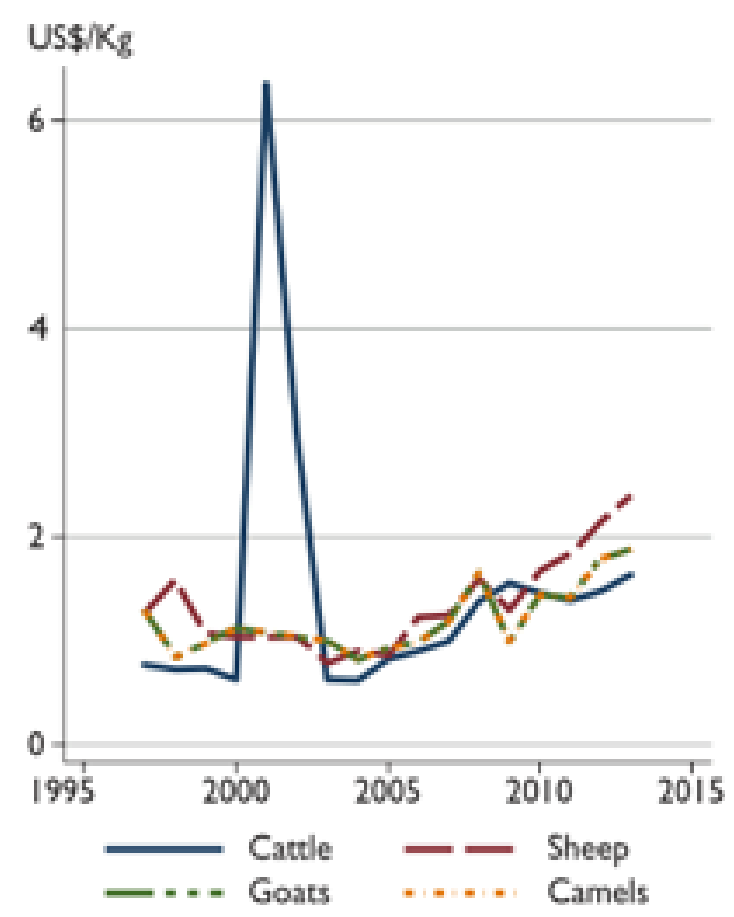

Source: ERCA (2013)

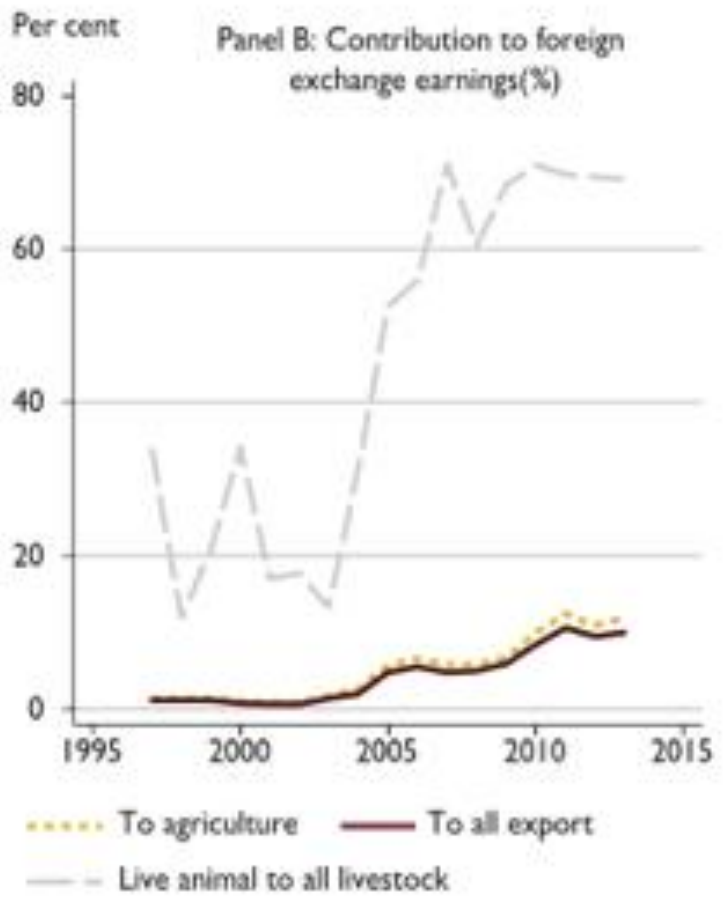

Source: ERCA (2013).

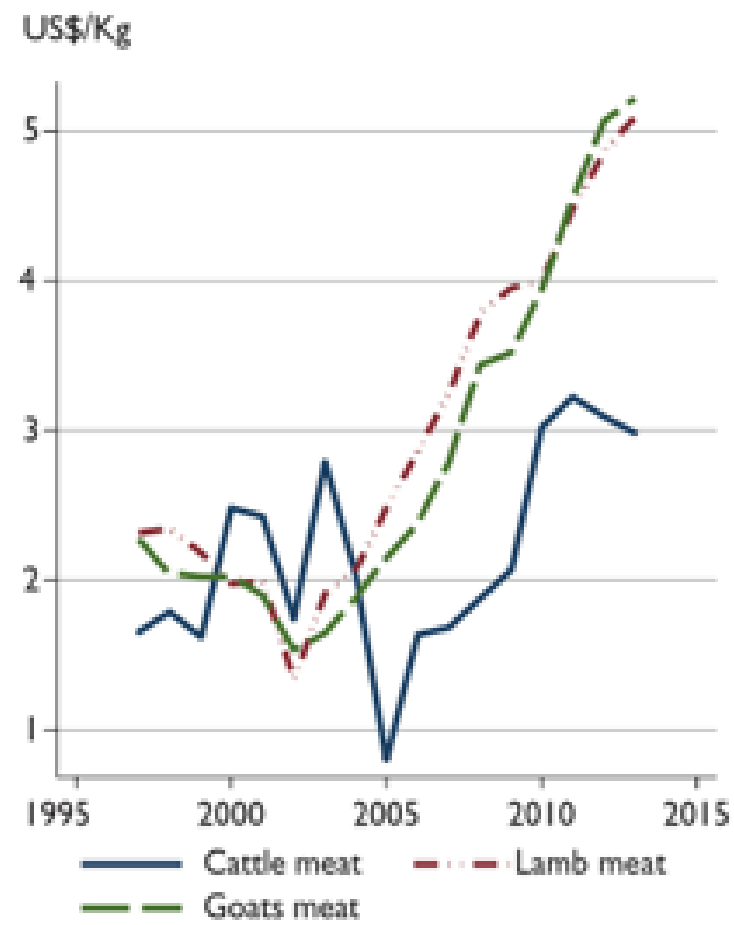

Source: ERCA (2013)

Despite continued efforts to increase live animal exports, the number fluctuates owing to several factors. According to Shapiro et al. (2017), "About $29 \%$ and $8 \%$ of the live cattle from the grassland (rangeland) and mixed systems, respectively, are exported through the formal channel. Meanwhile, about $58 \%$ and $5 \%$ of the live animals come from the grassland and mixed systems, respectively, and are exported through informal channels. Informal exports are more than double the formal exports, which has a very significant impact on the national economy, in terms of both lost revenue and high domestic prices." 
This study (Shapiro et al. 2017) of the beef VC analyzed the margins through different channels in the chain (see Table 2). It clearly shows the high meat prices local consumers pay relative to returns from live exports. It also shows that one of the attractions of informal live exports is the return of US\$2.95 per $\mathrm{kg}$ to the exporter.

Table 2: Average price and margins along the cattle VC (US\$\$/kg)

\begin{tabular}{|l|c|c|c|}
\hline \multirow{2}{*}{ Market actor } & \multirow{2}{*}{ Beef meat } & \multicolumn{2}{c|}{ Live exports } \\
\cline { 3 - 4 } & & Formal & Informal \\
\hline Producers & 5.05 & 2.16 & 2.16 \\
\hline Collectors (aggregators) & 0.06 & - & - \\
\hline Small traders & 0.18 & 0.17 & 0.17 \\
\hline Big traders & 0.37 & 0.20 & 0.20 \\
\hline Butchers & 3.09 & - & - \\
\hline Feedlot operators & & 2.06 & \\
\hline Formal live exporters & & 0.36 & \\
\hline Informal live exporters & & & 2.95 \\
\hline Consumers & 8.73 & 4.95 & 5.42 \\
\hline
\end{tabular}

It is significant that butchers capture 84 percent of the total gross margin in the domestic VC. Collusion among butchers enables them to control the beef market and impose artificially high prices on consumers. Once the price is raised for any reason, including increases in the price of slaughter animals, it never goes down (Shapiro et al. 2017).

\section{Meat processing}

Estimates for total production of beef in 2013 varied between about 810,000 tons and 877,000 tons. Meat processing, especially beef processing, is at a nascent stage, and the 17 or so export abattoirs are mainly freezing sheep and goat carcasses for export. Verde Beef is one example where cattle are fattened and slaughtered and carcasses airfreighted to Middle East markets.

Within the country, utilization of processed meat is generally limited to burgers and sausages. Ethiopians are considered a raw meat-eating people and little processing takes place. Raw meat is often sold by informal open-air butcheries with considerable health risks to consumers especially due to lack of refrigeration. There is evidence of an emerging market for a wider range of processed meat, particularly in Addis Ababa, where new processed meat products are available.

Related to beef exports, the newly constructed abattoirs have the facilities for slaughtering, processing, and freezing cattle carcasses. The hope is that these will help increase the volume available for beef export.

\section{Business Conduct}

The increasing demand for meat, fueled by economic growth and urbanization, is an impetus for business in the livestock sector. Two distinct markets have developed based on the type of livestock. The export market of live animals, as well as processed meat, requires relatively young animals not more than three years of age with a small amount of fat. On the contrary, the domestic market largely requires meat with a high degree of fat.This type of meat usually comes from oxen that have been retired from cultivation and put on a fattening program. Ethiopians have a culture of consuming raw meat, and the meat comes largely from the latter type of animals. However, there is a notable change in the behavior of consumers in the metropolitan cites, where they are increasingly requiring lean, tender meat. This signals the need for investment to produce quality animals (taking younger animals through feedlots, then to the slaughterhouse, and being processed into a variety of cuts and products). 
Compared to previous years, Ethiopia has paid better attention to the livestock sector. The sector, now headed by a State Minister, has developed a Livestock Master Plan to transform the livestock sector. Also, it is organizing livestock marketing within the agricultural marketing of the Ministry of Agriculture. Whether these institutional rearrangements result in tangible results is yet to be seen.

Despite these efforts, actors in the sector complain that the business environment has not changed much and reiterate that the policy efforts have not been translated into meaningful action -- it is still 'business as usual'. Moreover, the sector is dominated by individuals with no business or technical skill, resulting in unhealthy competition and market distortion. The middle men, who have little or no contribution to the chain, are getting an unfair share of the profit. Due to bureaucratic hurdles within the government offices, renewing licenses and getting permits is still complicated and prolonged.

\section{Sector investment and growth opportunities}

\section{1) MARKET}

Domestic and foreign market opportunities for Ethiopian meat and meat products are real. On the domestic side, there is an increasing demand of meat, influenced by sustained economic growth. The Middle East and Northern African countries (MENA) apart from proximity seem to have developed a preference for Ethiopian meat products. This is an opportunity to be secured.

Foreign investors are being attracted to the sector and there is increasing investment by domestic investors as well. In recent years, four new export abattoirs were established, all of them are equipped with facilities for slaughtering and processing cattle carcasses.

Smallholders in urban and peri-urban areas are also taking advantage of emerging markets targeting religious holidays. In the rural areas where small-scale fattening occurs, producers have no access to the urban market and sell their animals on the nearest available local market. The major purpose of this system is to get cash, regardless of the profitability.

\section{2) INFRASTRUCTURAL DEVELOPMENT}

There is a significant infrastructural development drive in Ethiopia. Road construction, railway access to additional ports such as Assab are all positive developments. Not only will inputs be transported easily but better roads will also include offtake of animals from the pastoral areas.

Assisted by the USAID project called Livestock Market Development (LMD), the MoA has successfully finalized a pilot project on Livestock Information and Traceability System (LITS). This is an important milestone to penetrate other potential markets and expand markets to counties that strictly require a traceability system.

\section{Challenges and constraints}

\section{i. $\quad$ Feed shortages}

For the feedlot operators, feed is a critical input. The quality of the finished product (fattened animals) as well as the duration of fattening depends on feed quality and quantity. Feed prices are exorbitant and fluctuate. Roughage sources are limited. The major source for many feedlots is straw, with the exception of Verde Beef, which produces its own silage. 
For pastoral areas, the rangeland which is the sole source of feed, is deteriorating. Bush encroachment, which is the invasion and thickening cover of undesirable woody species with a decrease in grass productivity and biodiversity, reduces the grazing capacity and results in concomitant economic losses. Bush encroachment coupled with climate change is threating the existence of cattle. Current statistics show the dominance of camels in the rangeland. The absence of a clear policy on rangeland management and lack of any intervention for improving productivity of rangelands is also contributing to the problem of feed shortage.

\section{Commercial feed production}

Elfora Agro-Industry embarked on high-value forage (alfalfa) production on 900 ha of land (Mekie and Bishan Guracha) using a high-tech irrigation facility. Sun-cured alfalfa hay was meant for export as well as the domestic market. The project invested more than ETB 400 million in water resources development and irrigation facilities to produce alfalfa year-round. In the beginning, performance was encouraging, and the company harvested alfalfa monthly. It also created employment opportunities for young people. It was hoped that it would contribute to technology transfer.

Unfortunately, the political turmoil caused damage to the facilities and the company is currently in need of ETB 100 million to rehabilitate the facility. The effort of this company shows that commercial feed production is feasible but also underlines that security is essential for the private sector. Alfalfa is still produced on a small scale and companies such as Verde Beef are long-time customers. An important limitation for commercial forage production is lack of appropriate seed, which needs to be addressed properly.

A study commissioned by the GoE to identify commodities that are profitable and worth investment included commercial feed production in the list. Unfortunately, that recommendation has not yet translated into meaningful action.

Feed production is also a victim of unwise policy decisions. About ten years ago, feed was identified and recommended as a profitable investment commodity. But for unknown reasons, it was dropped from the priority list.

There are about 50 small- to large-scale private and cooperative feed manufacturers in the country with capacities ranging from 0.5 to 12.5 tons per hour.

As clearly stipulated and reiterated in the Livestock Master Plan, unless the feed issue is properly addressed, the country will face an irreversible condition involving livestock production.

The newly established sugar factories produce molasses, which is an essential input to feedlot operation. Establishing feedlots in these areas or converting wet molasses into dry products is a potential investment area. Ranching and contractual farming are promising opportunities that should be considered to alleviate the shortage in supply of animals.

\section{ii. Lack of knowledge and entrepreneurship skills}

The livestock business is dominated by people who lack knowledge and entrepreneurship skills. Management capacity in the subsector is a huge problem. The common perception is that any person with some capital can enter the business and gain immediate profits. As a result, there is a high dropout rate. While the government trained and deployed agricultural development agents throughout the country,
Tax issues

Many of the processors who source animals from producers buy animals without a formal receipt. Sometimes, the processors have the producers/suppliers sign for the sale price. Unfortunately, the tax revenues agency does not acknowledge expenses that are not accounted for by formal receipts. This means that the cost of live animal purchase is not formally registered as expense, leading to higher taxation on the income. Prime Meats Plc currently faces this problem where costs of all processed bulls could not be considered as expenditures. 
a major limitation of extension workers was a lack of practical skills. The problem is aggravated in pastoral areas where appropriate extension messages that address the needs of pastoralists just do not exist.

\section{iii. Breed types}

There have been no endeavors to develop Ethiopian beef type cattle through selection and/or synthetic breed formation. In the past, there were crossbreeding programs aimed at increasing meat and milk yield of local animals by crossing indigenous cows with exotic breeds. There was also importation of Brahman cattle from Cuba in the 1980s, but currently, there is no trace of these animals. A recent proposal to import double-muscled Belgian blue cattle for improving meat yield as well as quality has not been implemented. Very few indigenous breeds of cattle may be considered as beef type cattle. The one that is well known is Borena cattle. The carcass weight of indigenous breeds is about $110 \mathrm{~kg}$ and it is $230 \mathrm{~kg}$ for improved or established beef breeds. This indicates that a lot must be done to improve the quality of indigenous beef type cattle to the level of standard beef breeds. Not only is the carcass weight low, but daily weight gain is also minimal. Feedlot animals are required to be efficient users of feed and cattle types known for better efficiency will be more economical in terms of feed prices.

\section{iv. Finance}

Lack of finance is another constraint faced by the sector. Those interviewed indicated that the sector is highly marginalized by financial institutions. Securing loans is a significant challenge. Even with 50 percent collateral provided by the Development Credit Authority (DCA) of USAID, many of the banks are not ready to provide loans to actors in the sector. Where some banks do provide loans, the financial product does not consider the nature of the business. For example, there are cases of loan recipients having to repay the loan before marketing their first batch of fattened animals, illustrating that loan terms need to match business cash flow cycles.

Financial services that offer working capital are limited. Regular banks have great difficulty providing appropriately structured loans. Since investment in feedlots or feed storage facilities are usually located outside urban areas and buildings are not built following the formal process of constructing buildings, banks do not treat them as collateral. There is a need to develop appropriately structured financial products. Additionally, the apparent favoritism toward exporters rather than the domestic market must be corrected and a balance established.

\section{v. Land}

Access to land is a major problem for feedlot operators, aggregators, and abattoir service providers. The requirement that entitles someone to get access to land does not take into consideration available land. For instance, a feedlot operator is required to have at least 5 ha of land in a rural area and 2 ha near an urban center to apply for an operating license. In many parts of the country, such a large tract of land is not available. In cases where land is available, it is leased with user rights for a limited period, which discourages meaningful investment. The period varies across regions, but generally is short.

A serious issue has been raised related to ranching. Investors interested in ranching often complain that that their request for land has been turned down many times. There are two opposing views when it comes to land. Some on the government side believe that there is no unoccupied land and displacing farmers for the sake of giving the land to someone for ranching is unethical. On the other hand, are those who argue that land is available, but the prevailing bureaucratic system is inherently prohibitive. Moreover, security issues in areas where land is available is discouraging any progress. Regardless of the arguments, it should be underlined that the present purely exploitive relationship of export abattoirs with livestock keepers is a major concern. If nothing happens, the livestock resources available in the rangelands will be depleted. Furthermore, the current unwritten code favors access to land for ethnic groups that belong to the area where land is available and discourages nonethnic members investment. 


\section{vi. Policy and regulatory constraints and solutions}

Driven by the dire need for foreign currency, existing policy focuses on exporters rather than traders and investors in the domestic market. An accommodating policy will have to be put in place to enhance the participation and role of non-exporters in the market. Access to foreign exchange for businesses in the local market should be made available as these businesses import capital goods and other inputs offshore. Government should revise its policy and give proportionate focus to supporting the domestic market. This should be guided by a change of principles from 'dollar hunting only policy' to collecting revenues from the increased domestic trade.

It is understood that export abattoirs are not allowed to sell their products on the local market or are only allowed to access a minor share of the market. Truly, this is done to protect the native smallholders. But, in the final analysis, such protectionism will decrease competitiveness and quality of products.

Except for abattoirs that focus on exports, many domestic abattoirs do not meet ISO standards. However, there is an urgent need to enforce the establishment of abattoir standards that would contribute to safety of the users, that is, consumers. The MoA has realized this and proposed establishing training institutes mandated to train meat inspectors and food safety specialists.

In general, Ethiopia has a conducive policy for making best use of resources from the livestock sector. The Livestock Master Plan, the meat strategy, and the many polices that are being drafted are examples of the improving policy environment. The Livestock Master Plan has been adopted as the road map. However, the translation of policies into real action is a big constraint that nullifies all efforts.

\section{Business risks}

The sector is exposed to many risks. The major risk for feedlot operators is accessing disease-free animals. Animals for feedlots are usually bought without testing for major diseases, notably foot and mouth disease (FMD). There are also occasions where the end market buyers do not recognize the certificate of the National Animal Health Diagnostic and Investigation Center (NAHDIC).

The MENA markets depend to a large extent on trust. Buyers are not willing to open letters of credit (LCs) and do not have the patience to follow standard established rules. This is a major reason for many of the actors to go bankrupt and get eliminated from the market.

Security in the country is also an important risk factor affecting investors. The political turmoil over the last couple of years has devastated some firms.

The source for live animal export is narrowly limited to lowland animals, specifically the Borena cattle. The herd of Borena cattle is under threat because of recurrent drought and poor rangeland management. As the end market, MENA seems to have developed a preference for this type of animal, the dwindling numbers of Borena cattle is a potential risk, especially for live animal exporters.

\section{Business development support}

The Ethiopian Meat and Dairy Industry Development Institute (EMDIDI) was established with a mandate to provide various kinds of support to commercial livestock producers. The support includes appraisal of business plans, provision of training, and advocacy on behalf of investors, as the need arises. In most cases, the institute writes letters of support to various institutions to assist newcomers to invest in the livestock sector. The MoA also provides quarantine services for live animal exporters. Building the capacity of the EMDIDI and making it a center of excellence to provide services to the actors in the sector is essential.

Five years ago, the MoA tried to shorten the long VC of live animal export, with the intention of bringing the producers and feedlot operators together in a common market center. Unfortunately, the rules and laws governing such interaction were not implemented, primarily because the market 
centers, a prerequisite for shortening the chain, were not in place. After realizing this problem, market centers are being built, and there is a recommendation to create and pilot an auction market. The radical steps that are being undertaken by the government to open more space for business is also a positive gesture for business in Ethiopia.

Access to the Eritrean port of Assab and Massawa, which needs to be rehabilitated, provides new opportunity for exporters. It is reported that rehabilitation of the structures in these ports has started. It is hoped that these will be operational in the foreseeable future.

\section{Opportunities for inclusive business models}

As the resource base for live animal exporters and processors is the same, it creates unnecessary competition. There is a need to broaden the base for sourcing animals. Buying young animals (weaners) and fattening them could yield better-quality animals. This can be achieved through provision of proper feed and adopting improved management practices.

Licensing is also an important aspect that could affect business. There is a notion that compliance with export licensing can be manipulated by collusion between

Relationship between feed cost, informal trade, and cash sale The foremost challenge most often reported is informal trade of animals across the border. The exorbitant feed costs in Ethiopia do not provide a good profit margin for feedlot operators. On the other hand, feed prices in the end markets are said to be far cheaper and informal traders know that once the animal crosses the border, it could be fattened at a cheaper cost and add more value. In addition, the cross-border transaction is made in U.S. dollars, which enables livestock traders to buy basic commodities in U.S. dollars and return to Ethiopia to trade imported goods. It is assumed that basic commodities are cheaper and available in the cross-border markets.

officials and feedlot operators. This can be avoided by setting clear and transparent guidelines on licensing requirements that consider existing practices.

Development of agroindustry parks that can provide one-stop shopping service and harmonize products from development wing to manufacturing is a new, unfolding opportunity.

\section{Product development}

Many Ethiopians have a culture of eating raw meat. The few that do not enjoy raw meat usually eat roasted meat; eating processed meat is not common. However, there is an emerging niche market in major cities and consumption of fresh processed meat such as hamburger and sausages is on the rise. Development of processed meat products should be an integral part of a beef business. Currently, the number of meat products available on the market is quite limited. However, this does not imply that there is no demand for the products. Some meat processors have experimented with the use of Ethiopian spices to develop products that meet the taste preference of consumers. Drying meat is an age-old meat preservation technique in many places, including Ethiopia. Developing meat products based on dried meat not only will increase the shelf-life but also will ease distribution to areas where there is no means of refrigeration. There is an urgent need for packaging in small amounts. Where the price of meat is increasing and people cannot afford a kilogram of meat, supplying the market with small packs of meat, for example, $250 \mathrm{~g}$, is essential.

\section{Principles for nutrition-based food systems}

Food and nutrition security have been set as one of the SDGs. Access to animal source food plays an important role in the fight against malnutrition and consequently reduces stunting. Meat is not only an excellent source of protein but also of micronutrients, which are needed for healthy growth and development in children. Studies have shown that inclusion of a small amount of meat in complementary food for children will markedly increase their growth rate. In this context, the beef 
sector is facing the challenge of providing the small quantity of meat required for such purpose. It is high time that business takes this agenda forward and works toward packaging of meat in small quantities.

\section{Investment in human capital}

Several universities offer courses in food science and technology. However, graduates from such faculties do not serve the meat sector because they lack hands-on experience. The EMDIDI's tailormade short-term trainings were supposed to fill such gaps. To date the EMDIDI does not have a mini abattoir to provide training, such as meat processing.

This should be seized as an opportunity and every effort made to develop human capital in this field. The findings of the study show that some abattoirs are employing expatriates as there is no local source. The same applies for livestock nutrition specialists. Large-scale feedlot operators are hiring animal nutrition consultants just to advise them on feed and ration formulation. In the Livestock Master Plan, the MoA has indicated the need to have an institute for training meat inspectors and food safety specialists. Currently, veterinarians are filling the gap of meat inspectors. Without appropriate training institutions, having independent meat inspectors and quality assurance services is not feasible.

\section{Opportunities for PPPs}

Two areas, namely livestock market structures and abattoirs, were identified as potential opportunities for PPPs in the beef sector. In the past, livestock markets have been built by various projects and regional governments. The management of many of these marketplaces is under municipalities. The management and performance of these marketplaces have not been efficient.

There are about 296 municipality managed slaughterhouses scattered across the country. It is reported that the condition of these abattoirs in terms of buildings, facilities, and hygiene is extremely poor, raising food safety concerns. Applying a PPP model is one strategy to encourage private sector investment, achieve improved health standards and meat quality, and bring efficiency to these sectors.

\section{Investment in research}

Research in the beef sector offers several opportunities. The Borena breed, which is preferred by consumers in MENA, can be further improved by importing improved bran germ plasm from Kenya or Australia. The dairy industry is producing male calves (mostly crossbred calves) that are not wanted by the dairy industry. This offers research as well as investment opportunities to venture into dairy beef production. Crossbred dairy bulls are relatively large-frame animals and can be grown at a rapid rate without over fattening.

Initially, investment in production facilities for vaccines against FMD and Rift Valley Fever (RVF) could be an important, solely public investment opportunity that can ultimately be privatized when market conditions are sufficiently developed.

\section{Investment in infrastructure}

Development and expansion of ranching in the pastoral areas is restricted by the lack of water for animals. Developing water resources should not be left to investors only. It demands involvement of the public sector. Previous water development endeavors for supplying water to range animals was based on construction of ponds in water catchment areas. This practice has now been abandoned due to environmental sustainability concerns. More groundwater resources need to be identified. 


\subsection{Annex 3: Coffee Value Chain Description}

Contribution to the economy - Subsector overview

The Ethiopian economy is currently highly dependent on agriculture, which contributes about 40 percent to GDP and 80 percent of export revenue. Coffee is a major agricultural export crop, which in the past provided about 60-70 percent of annual export values but now provides about 22-30 percent of annual commodity export earnings (Kufa 2015). The 2016/17 export earnings reached US\$897 million with the export of about 232,000 tons of coffee.

In GTP II, the GoE set a goal of more than doubling coffee production by 2020 to achieve a 1-millionton annual target. This target is unlikely to be achieved. A new target set by the ECTA of tripling production by 2024 will require a significant response by the private sector.

\section{Production}

Ethiopia is known as a center of origin for coffee Arabica, with a diverse genetic base of considerable heterogeneity-more than 10,000 different varieties. There is also a conducive agroecology to produce these different varieties in different parts of the country (Minten et al. 2014), the most notable being Jimma, Sidama, Wellega, Yirgacheffe, and Harar.

Of the four types of coffee cultivation in Ethiopia, three are by smallholders, accounting for 90 percent of production. Forest coffee is wild Arabica coffee grown under the shade of forest trees (something no other country has), accounting for 10 percent of output. Semi-forest coffee has some level of tree management by farmers living nearby and accounts for 35 percent of production. Garden coffee is produced in the farmer's backyard using organic fertilizer to boost production, intercropped with other crops, and accounts for 45 percent of total production. Plantation coffee is produced by commercial private investors and accounts for 10 percent of total production on around $45,000 \mathrm{ha}$.

Production per hectare across the various managed types is shown in Figure 7.

Figure 7: Ethiopian Coffee Yields Across Production Systems

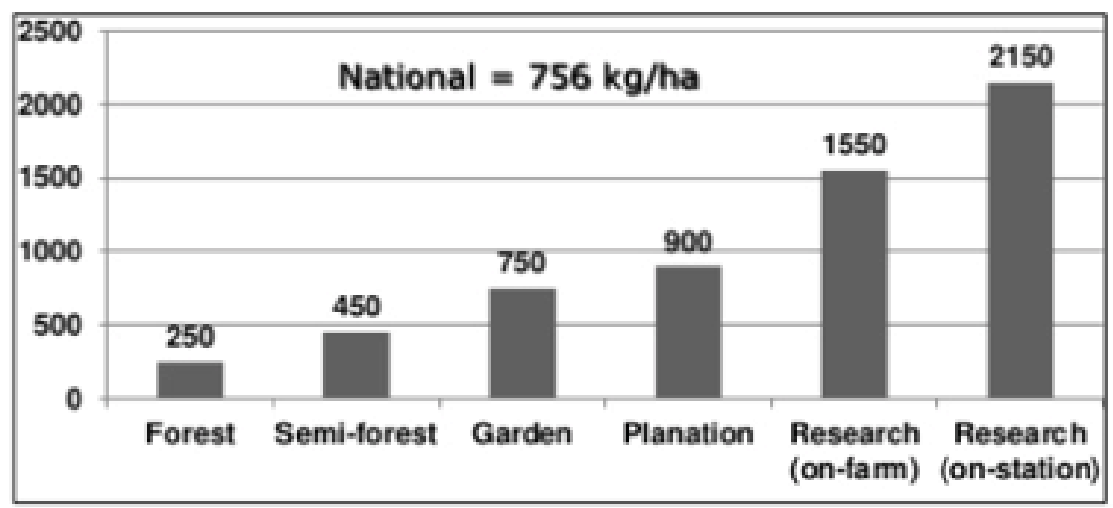

(Source: Kuma 2015)

An estimated 5.4 million ha of land is suitable for coffee production. Of this potential area, estimates of areas under coffee vary from as high as 1.2 million ha under coffee but only 0.9 million ha was productive in 2009 (Tsegaye 2017) to a low of 0.662 million ha (10 percent of potential) more recently (Kufa 2015).

Coffee plays a significant role in the socio-economic health of the country. It contributes to the livelihoods of between 15 and 20 million people, with around 4.7 million smallholder farmers and employment for an estimated 8,000 permanent and 50,000 seasonal casual workers. (Birhanu and Daniel 2013; Kufa 2015; Tsegaye 2017; USAID 2010). 


\section{Processing}

Cherry coffee is either sun-dried or washed-about 70 percent and 30 percent, respectively. Including the domestic market, Kufa (2015) reports the proportion of unwashed at 59 percent and washed at 41 percent of total production. This is significant as it is reported that washed coffees achieve a 20 percent price premium above sun-dried and hulled coffees.

For washed coffee, the fresh red berry is pulped in WSs immediately after harvesting, fermented in tanks, and washed and the bean sun-dried. During this process, the poorer quality and diseased beans are separated from good-quality beans. After drying, they are packed in $60 \mathrm{~kg}$ jute bags and shipped either to the buyer's warehouse or to one of the 22 regional ECX warehouses for grading. ECX samples the delivered coffee, grades it, weighs, and stores it until purchase.

For sun-dried coffee, smallholders sun-dry much of the cherry and then sell the dried product to a dehulling plant. As with washed coffee, the hulled product is bagged and sent to ECX warehouses for grading and storage until being sold.

\section{Trading of coffee}

During the picking season, farmers have the option of natural sun-drying at home and later sale to a hulling plant, giving them the possibility of all-year sales or sale of fresh red cherry (berry) during a short harvest period. They either sell the cherry to their primary cooperative, to private traders, referred to as collectors or Sebsabies, licensed by the State; and if located near enough, to wholesalers who have WSs (it is estimated that there are some 4,500 WSs, of which many are underutilized). The traders (collectors) either collect directly from the farmer or buy at the local primary market center and may on-sell only to wholesalers. These wholesalers may have their own warehouse but mostly use ECX facilities. ECX estimates that there are 116 such wholesale traders who are not members of ECX and hence they sell through an ECX member or broker. ECX has a total of 346 seats, or members, across all commodities, of which 150 are specifically for coffee.

Historically, the bulk of the coffee product is sold through ECX. In 2017, ECX reported that 336,000 tons, or 5.6 million bags, out of the 450,000-ton crop was sold through ECX or directly to exporters, the latter accounting for 10 percent of the crop. For exporters, there is a 2 percent withholding tax that applies and for local sales, VAT of 15 percent.

The recent changes in regulations for coffee marketing in line with Proclamation 1051/2017 allow exporters to buy directly from washing or hulling stations, which will contribute to better traceability and a shorter VC of actors.

\section{Trends in production, consumption, and exports}

A history of production, consumption, and exports of Ethiopian coffee is presented in Table 3. Local consumption of the coffee crop is high, at about 50-53 percent of production. This demand is met by household-level roasting and an ever-increasing number of formal roasting businesses, which have reportedly grown to around 200, with 150 in Addis Ababa alone.

Exports are undertaken by those registered with the ECTA-reportedly 323 registered exporters. Some sources indicate there could be a much higher number, even as high as 450 , as applications for registration are not yet finalized. Major MNC coffee importers generally make use of local representatives or agents to source on their behalf to meet their purchase requirements. 
Table 3: Ethiopian coffee production, domestic consumption, and exports (2003-2017)

\begin{tabular}{|c|c|c|c|c|}
\hline & $\begin{array}{c}\text { Total production } \\
(000 \text { ton })\end{array}$ & $\begin{array}{c}\text { Domestic consumption } \\
(000 \text { tons })\end{array}$ & $\begin{array}{c}\text { Export } \\
(000 \text { ton })\end{array}$ & $\begin{array}{c}\text { \% share of } \\
\text { consumption }\end{array}$ \\
\hline 2003 & 313 & 168 & 145 & 54 \\
\hline 2004 & 287 & 127 & 160 & 44 \\
\hline 2005 & 339 & 180 & 153 & 54 \\
\hline 2006 & 358 & 182 & 176 & 51 \\
\hline 2007 & 297 & 126 & 171 & 42 \\
\hline 2008 & 416 & 282 & 134 & 68 \\
\hline 2009 & 450 & 278 & 172 & 62 \\
\hline 2010 & 408 & 212 & 196 & 52 \\
\hline 2011 & 374 & 205 & 169 & 55 \\
\hline 2012 & 386 & 187 & 199 & 48 \\
\hline 2013 & 395 & 204 & 191 & 52 \\
\hline 2014 & 403 & 219 & 184 & 54 \\
\hline 2015 & 438 & 239 & 199 & 55 \\
\hline 2016 & 459 & 233 & 226 & 51 \\
\hline 2017 & 449 & 211 & 238 & 47 \\
\hline Average & 384 & 203 & 181 & 53 \\
\hline
\end{tabular}

(Source: Kuma 2018)

\section{International position}

Five MNCs, Nestlé, Philip Morris, Procter and Gamble, Sara Lee, and Kraft Foods, account for about 70 percent of the world's coffee and play pivotal roles in setting world coffee prices (Poor Farmer BlogSpot, posted August 3, 2009).

More than 70 countries produce coffee, with about 50 as exporters, implying a competitive market on the supply side and a monopsonistic market on the demand side. For producers to be competitive, it requires high productivity, efficiency in logistics, and a stable exchange rate (Kuma 2018), areas that could be improved in Ethiopia. Coffee is exported to 58 countries, of which 53 percent is destined for the European Union (EU) market.

Ethiopia is the leading coffee-producing country in Africa, with about 384,000 metric tons annually, and the fifth-largest producing country globally after Indonesia, Colombia, Vietnam, and Brazil. The local Ethiopian coffee sector share of global physical export volumes is between 3.9 and 4.5 percent and now, in terms of global value, about 2.9 percent. This could partly be attributed to limited value addition as Ethiopian coffee is exported in green form and not as roasted nor decaffeinated. For example, data from 2010 indicated value-added coffee makes up only 0.04 percent of volume and 0.1 percent by value of exported coffee. It appears that there is a marginal upward trend in Ethiopia's share in the value of the international market (Figure 8) but on aggregate, it is still small. 


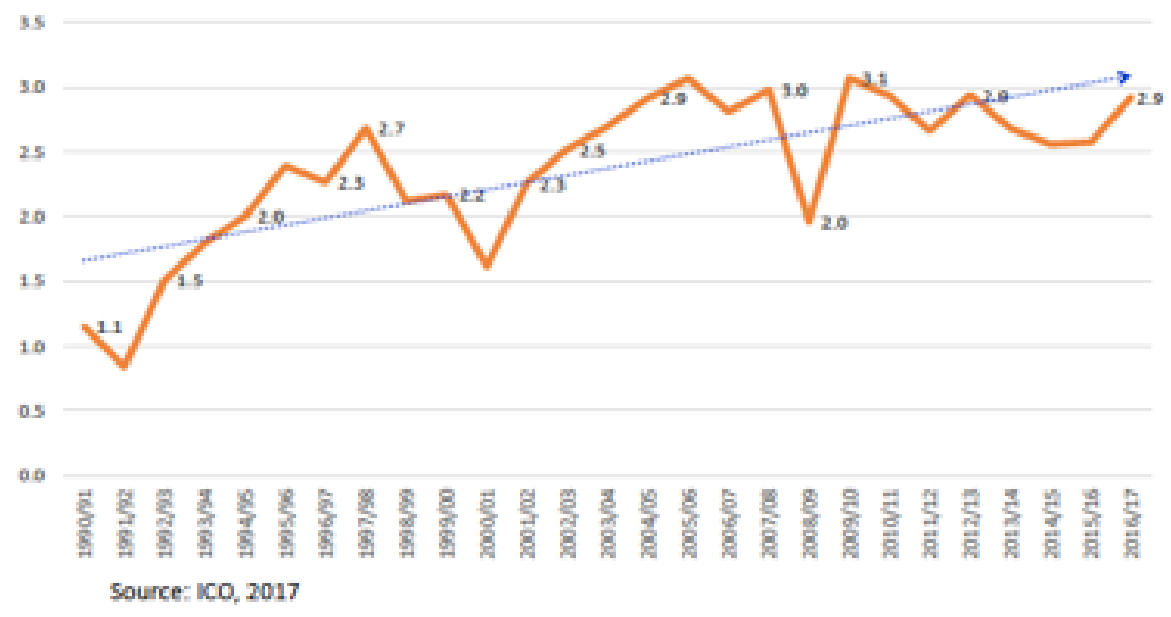

(Source: ICO 2017)

\section{Institutional Mapping}

\section{The Ethiopian Coffee and Tea Development and Marketing Authority}

The Ethiopian Coffee and Tea Development and Marketing Authority, reestablished in 2015, has a mission of identifying and addressing challenges in the development and marketing of coffee. Its mandate is to control and regulate the market, from issuing and revoking trading licenses to carrying out quality inspection in accordance with the coffee market control and regulation proclamation. It also has the mandate to provide an extension support program at the regional level and promote coffee and tea within the country and in the international market.

The ECTA has initiated a process to develop a road map and strategy to achieve the ambitious goals for the coffee sector. This Comprehensive Ethiopian Coffee Strategy and Implementation Roadmap (CECSIR), when finalized, should contribute to addressing sector constraints.

The ECTA reports that there are around 7,000 EOs in the country employed through the regional governments, but there is high turnover due to poor employment conditions.

Figure 9: Institutional Mapping of State Function Across the Coffee VC

\begin{tabular}{|c|c|c|c|c|c|}
\hline Organization & $\begin{array}{l}\text { Research \& } \\
\text { Development }\end{array}$ & Input Supply & Production & Processing & $\begin{array}{l}\text { Distribution \& } \\
\text { Marketing }\end{array}$ \\
\hline \multirow[b]{2}{*}{$\begin{array}{l}\text { Ministry of Agriculture - } \\
\text { Ethiopian Coffee \& Tea } \\
\text { Authority }\end{array}$} & \multicolumn{5}{|c|}{ - Provides policy and regulatory environment } \\
\hline & & $\begin{array}{l}\text { - Formulate strategies } \\
\text { and lead the extension } \\
\text { service, }\end{array}$ & $\begin{array}{l}\text { - Quality inspection at } \\
\text { primary market level }\end{array}$ & $\begin{array}{l}\text { - Inspection of } \\
\text { Washing Stations } \\
\text { through EO s }\end{array}$ & $\begin{array}{l}\text { - Registration and } \\
\text { accreditation of } \\
\text { exporters and traders, }\end{array}$ \\
\hline $\begin{array}{l}\text { Regional Bureaus of } \\
\text { Agriculture }\end{array}$ & & - Extension Officers & & & \\
\hline $\begin{array}{l}\text { Ethiopian Institute of } \\
\text { Agricultural Research - } \\
\text { Jimma Agricultural } \\
\text { Research Centre } \\
\end{array}$ & \multicolumn{4}{|c|}{ - Generate improved agronomic \& processing technologies, germplasm collection \& breeding } & \\
\hline \multirow{4}{*}{$\begin{array}{l}\text { Ethiopian Coffee } \\
\text { Exchange }\end{array}$} & & & \multirow[t]{4}{*}{$\begin{array}{l}\text { - Warehouse receipting to } \\
\text { producers }\end{array}$} & & $\begin{array}{l}\text { - Storage and transport } \\
\text { of coffee bean }\end{array}$ \\
\hline & & & & & \begin{tabular}{|l|} 
- Trading platform, \\
\end{tabular} \\
\hline & & & & & $\begin{array}{l}\text { - Quality certification } \\
\text { via Coffee Liquoring Unit }\end{array}$ \\
\hline & & & & & - Market information \\
\hline \multirow{2}{*}{$\begin{array}{l}\text { Ethiopian Grain Trade } \\
\text { Enterprise }\end{array}$} & & & & \multirow[t]{2}{*}{ - Cleaning of coffee } & \begin{tabular}{|l|} 
- Storage \& \\
transportation
\end{tabular} \\
\hline & & & & & - Trading of coffee \\
\hline \multirow[t]{2}{*}{ Cooperatives } & & \begin{tabular}{|l} 
- Produce and \\
disseminate seed
\end{tabular} & & \multirow[t]{2}{*}{ - Wash cherry } & \multirow{2}{*}{$\begin{array}{l}\text { - Purchase and store } \\
\text { coffee, trade coffe } \\
\text { through ECX }\end{array}$} \\
\hline & & -Sell inputs to members & & & \\
\hline
\end{tabular}




\section{Ethiopian Commodity Exchange}

ECX was established in 2008, by proclamation No. 550/2007, as a partnership between the GoE and private investors. In August of the same year, by proclamation, all coffee trading had to be through ECX This was initially met with huge resistance from exporters and international importers who wanted to continue with the existing system that systematically disadvantaged the smallholder (Gabre-Madhin 2009). It has now grown to an organization employing 800 people. ECX is regulated by the Ethiopian Commodity Exchange Authority (ECEA), under proclamation No. 551/2007. ECX is a result of the pioneering work of its former CEO and economist Eleni Zaude Gabre-Madhin, who researched Ethiopian agricultural markets with the International Food Policy Research Institute (IFPRI). Her research showed that grain traders lacked infrastructure and access to credit, market information, transportation, and the ability to enforce contracts. ECX is a multicommodity exchange that provides a trading platform for buyers and sellers to trade spot contracts of coffee, sesame, maize, wheat, haricot beans, and, more recently, soya and chickpea. Additionally, ECX provides a warehousing, grading, and payment clearing system. Shareholders are not permitted to be members of the exchange.

Various categories of membership (that is, brokers) exist as a means of controlling the trading. Membership is commonly referred to as a "seat". Full membership is permanent and can be transferred. It was reported that these seats are valued at ETB 6 million (approximately US\$215,000). Limited memberships are for smaller operators and are limited to trade on one side of the market (either as sellers or buyers) and are categorized as either trading members, who can trade on behalf of themselves and others, and intermediary members, who can only trade on behalf of others (that is, exporters, wholesalers, or local roasters).

Around 336,000 tons of coffee ( 5.6 million bags) is traded currently through the ECX floor $(250,000$ tons export and 50,0000 tons local). This represents approximately 70 percent of the total annual production of coffee and 56 percent of all commodities traded.

ECX receives green bean into storage and grades the coffee when it is received. Warehouse receipts are issued, which facilitates a level of access to credit.

ECX has a sophisticated multi-modal MIS using electronic ticker, mobile phone SMS, website, bulletins, radio, TV, and an information center. The immediate trading information is accessible only to members and traders. Other market actors experience a delay in accessing this information and large international importers have expressed a need for a more readily accessible, real-time market information system, which includes better estimates of production and quality reports.

\section{Ethiopian Grain Trade Enterprise}

The $\mathrm{EGTE}^{7}$ was initially established to stabilize the price of grains but was unsuccessful in achieving this objective. It was reorganized in 1999 for the purpose of purchasing grain, oilseeds, and pulses both for local wholesale and export. Since 2009, the EGTE has diversified its business to include coffee export. This is through 10 branch offices and 91 trade centers throughout the country.

It is a large organization with 1,415 permanent staff and 500 contract employees with an annual turnover of ETB 1.8 billion (US\$98 million).

The EGTE has an in-house logistics component with warehouses having capacity of 820,000 metric tons of grain and coffee. In addition, it has its own fleet of heavy and light trucks to facilitate its export and domestic operation.

Specifically, for coffee, the EGTE has modern coffee cleaning machines that can polish, sort, clean, and bag 90 metric tons of coffee per day.

\footnotetext{
${ }^{7}$ http://www.egte-ethiopia.com/en/about-egte/egte-structure.html.
} 


\section{Research institutions}

JARC, established in 1967, coordinates coffee research nationally; development of high-quality, highyield, and disease-resistant coffee varieties; and provision of improved seeds.

\section{Financial Institutions}

\section{National Bank of Ethiopia}

The National Bank of Ethiopia has a clear mandate, which includes formulating, implementing, and monitoring of the country's exchange rate policy. It sets the minimum interest rate on savings deposits (currently 7 percent as per Directive NBE/INT/12/2017) through its Monetary Committee; controls the supply of money in the economy; and acts at the government's banker. The bank issues various directives to commercial banks on how their business is to be managed. Foreign exchange is of particular concern to the coffee VC actors due to claims that there are entities that use coffee exports as a means to generate foreign exchange to finance imports. According to the National Bank directive FXD/46/2017 of March 20, 2017, "A bank by no means shall allocate foreign exchange collected from an exporter to import business of the same outside the proper procedure stipulated under article 6 above." Given the complaints by private actors in this regard, it would appear that there is still a level of circumvention of this directive.

\section{Development Bank of Ethiopia}

The DBE is a state-owned, development, financial institution, supervised by the Public Financial Enterprises Agency in Ethiopia, with 110 branches across the country. Stakeholders report that lending rates are more attractive than those of the private banks (about 9-11 percent).

\section{Commercial Banks}

The Commercial Bank of Ethiopia (CBE) is possibly the most important bank for credit as in June 2015 it held about 67 percent of all deposits in Ethiopia and 53 percent of bank loans.

There are around 16 private banks that advance loans to different VC actors such as farmers' cooperative unions, processors, and exporters. VC actors indicate that these banks have high lending rates (15-17 percent) and collateral requirements ( 2 to 6 times loan value).

\section{Cooperative Banks}

The Cooperative Bank of Oromia is a special type of private bank whose shares are held mainly by cooperatives and are an important source of finance for them, especially for working capital to procure cherry at the harvest season.

\section{Sectoral Associations}

\section{Ethiopian Coffee Exporters Association}

The ECEA was formed in 1969 and its main objective is to promote Ethiopian coffee in the world market. Additionally, the ECEA provides a range of services to members such as facilitation of cupping training and seminars, dissemination of industry information, and lobbying of the government on behalf of members.

Membership numbers are reportedly around 160, representing about 85 percent of all exported coffees. A membership list indicates 80 , compared to reports of some 300 ECTA-registered exporters. The association is also a corporate member of all the main production and marketing regional coffee associations.

\section{Ethiopian Coffee Roasters Association}

This association was established in 2004 by 13 stakeholders. Membership consists of 6 large roasters and about 150 small-scale roasters. 
The association receives some support from the ECTA through provision of office facilities. It needs additional funding and capacity building support as income from membership fees is limited, with membership fees set at ETB 2,000 per year.

\section{Constraints}

Despite the potential of the coffee sector, there are a large number of constraints that hinder its growth and achievement of its true international potential. These include: (a) low production per hectare at about 11 bags per ha (approximately $660 \mathrm{~kg}$ per ha) versus Brazil at 24 bags per ha (approximately 1,440 kg per ha) (Kuma 2018); (b) continued use of old trees past their optimum bearing potential with 50 percent of farmers reporting difficulty in sourcing reliable improved varieties (Minten 2017); (c) high-value crops threatening coffee production (for example, Chat or Khat); (d) high local consumption; (e) farmers' limited know-how on GAP; (f) a system of low standards for tree maintenance; (g) high transaction costs in the VC (refer to Error! Reference source not found.) $i$ ndicating the number of VC actors; (h) weak specialized coffee extension services; (i) inadequate management of warehouses and logistics; (j) existence of unethical business practices; (k) high price inflation; ( $\mathrm{I}$ ) very old equipment at WSs; $(\mathrm{m})$ lack of traceability; $(\mathrm{n})$ limited value addition; and (o) difficulties in access to finance and facilities for small and medium processing enterprises.

Highly regulated markets tend to be inefficient if the required bureaucracy is inadequate. Coffee is an industry that is highly regulated but with recently adopted new reforms. However, enforcement of some regulations appears weak and the benefits of the reforms are still to be realized. Coordination and integration of related interests between different organizations also seems weak, further exacerbating the situation.

The outcome of the interaction of all these factors is that Ethiopian farmers receive 60 percent of the export price, compared to 94 percent in Vietnam, 90 percent in Brazil, and 86 percent in Colombia (TechnoServe 2014).

\section{Coffee quality}

If the Ethiopian coffee sector is to improve its international positioning and returns to farmers and VC actors, quality needs to be addressed. According to Musebe et al. (2007), 40 percent of coffee quality is determined at field management level, 40 percent at primary processing, and only 20 percent during export processing and handling. This clearly indicates that good coffee is not determined by the roasting of beans but field management and drying/washing are the most important factors and need priority attention.

\section{Business conduct}

Farmer conduct: Farming of coffee is exclusively in the hands of private businesses, whether smallholder, micro-business, small, medium, or large through to multinationals.

The production motives that drive smallholder farmers, who produce 90 percent of the crop, lay the foundation of the industry. During the picking season, farmers have the option of natural sun-drying at home and later sale to a hulling plant or sale of fresh red cherry (berry). Decisions on options are based on perceptions of risk and reward. Red cherries need to be delivered to a WS within 10-12 hours of picking (Tamru and Minten 2015). Farmers do not sell to a WS (ibid.) for the following reasons: (a) the WS is distant; (b) false perceptions that selling red cherry is less profitable than naturally dried, whereas in reality wet processed bean achieves a 20 percent price premium compared to naturally dried coffee; (c) naturally dried cherry is considered a type of savings mechanism as farmers have little access to or seldom use institutional savings systems; (d) cherries that are harvested too early are not suitable for wet processing and receive a lower price but farmers are concerned about theft if they wait for proper ripening; (e) as farmers do not share the proceeds with their wives but still expect them to provide food for the household, many wives and children in the household undertake a 
practice of "strip-harvesting" and side-selling of immature cherry at reduced prices, without the head of the household's knowledge, as a means to get cash for their needs; (f) farmers do not trust the GoE price guide and think they can get better rates; $(\mathrm{g})$ there are too few red cherry buyers, therefore requiring more marketing efforts from farmers.

To overcome some of these perceptions, Tamru and Minten (2015) suggest (a) setting sale dates by the GoE, (b) providing more information on market prices through radio and mobile communication, (c) incentivizing investment in more WSs, (d) encouraging more formalized savings and credit groups and institutions, (d) ensuring quality improvement training of farmers, and (e) encouraging more sales to WSs through better information dissemination and better price transmission to smallholders. Primary cooperatives, of which reportedly 10 percent of smallholders are members, are prepared to pay a premium price but report that they have liquidity challenges and so buy only about 33 percent of the coffee crop.

In addition, educating household heads that dedicating a share of coffee revenue to their wives would incentivize the wives to protect the cherry for sale at the correct stage and for a better price.

Washing stations: WSs are either owned by primary cooperatives or private processors, who are essentially wholesalers. The new regulations allow for wholesalers or traders and exporters to integrate vertically into ownership of WSs. Many are looking at this as a means to ensure access to quality supply that, as per the trend in customer requirements, is traceable. However, they report difficulties in accessing land to set up operations, as it is usually only those with a connection to the local farmer community who are able to acquire land.

Green bean traders and exporters: Roughly 75 percent of the coffee is currently sold through the ECX trading platform, where brokers are registered to either sell or buy on behalf of traders or exporters. Some exporters hold both an export and a trader license. After they stock the coffee at their warehouse, as exporter they bid up the price on ECX for small lots to set a certain price, and then as trader they auction the larger volumes at the higher price level.

Some coffee exporters market specialty coffee. Rather than buying from suppliers through the ECX auction floor, they source coffee at the WS level, thereby ensuring they have the right quality coffee through controlling the pulping, washing, drying, cleaning, and grading to the agreed requirements of the buyers. These exporters usually also either have their own warehouses and processing stations, where cleaning of the green bean through parchment removal is done, or they contract the cleaning function to a reputable entity. Controlling the VC activities in this manner ensures they are able to guarantee traceability.

There are reports of some exporters manipulating export coffee trades to raise foreign exchange to finance imports, often of unrelated goods. This practice is reportedly attracting many more traders to the sector as they see an opportunity to access foreign exchange for their import businesses rather than having coffee as their primary business. The practice is to buy any export-grade coffee and then export it, reportedly at between 20 percent and 30 percent discount. Thereafter this "loss" is made up through profit on the sale of imported goods. While there is strict regulation on this practice, many still seem to be able to circumvent the regulations, presumably through collusion with bank officials and related importer companies.

It is also reported that some unscrupulous exporters blend poorer grades with better grades to pass off the shipments as higher graded coffee.

The above practices are damaging to the industry's reputation on international markets.

Warehousing, cleaning, and distribution: ECX is a significant warehouse owner with 22 sites. The single biggest private facility is at Horizon PLC in Addis Ababa, with a 45,000-ton capacity. This facility is a fully integrated service, offering truck parking facilities, warehousing, cleaning, packaging, and labelling. In addition, CLU quality check and customs clearance services are available on site. Apart 
from this processing facility where the parchment is removed before export, there are 70-80 other processors in Addis Ababa. One of the processors is the EGTE, a SoE that has the capacity to polish, sort, and clean 90 tons per day.

To date, ECX has graded beans on receipt. Grade is the most important determinant. However, beans of the same grade get mixed with beans from different WSs in the same region, thus neutralizing traceability. This business practice will have to change if traceability of a grade from a subregion becomes a more important market driver.

ECX reports its biggest challenges in offering a trading service have been (a) no structured market initially and (b) setting up of the business and development of an electronic management information system (MIS) with poor ICT infrastructure nationally. Continued challenges include (a) poor road networks, (b) lack of warehousing management skills, and (c) power reliability and access to the power.

Importers: The major MNC importers use agents that procure from exporters. Their interest is in procurement of green bean to meet their international commitments. Several respondents indicated a growing need for traceability of coffee to support their marketing needs. They also require improved market intelligence systems to identify transactions, market size, and movements on a real-time basis to assist in market decisions.

There have been claims that some of these agents accept incentive payments to buy from certain exporters, even at slightly inflated prices to that available from competing exporters. Given that purchases are on the basis of quality requirements of an international buyer located in a distant office relative to price, this is a difficult claim to prove.

There are efforts by, for example, Starbucks through its farmer support unit, to assist smallholders achieve higher yields and to apply GAP standards to achieve better quality. Initiatives to deepen the penetration and level of outreach of this sort of support program would benefit smallholders.

Export versus local market: The dual export and local markets created through regulation and based on grades results in two price levels. The local market prices for what is essentially poorer quality coffee is higher than export prices due to differences in the price formulation systems of the two markets. This price and quality differential is the driver of a system of leakages as traders employ strategies to circumvent the export market if they are able to sell at a higher price on the local market. To drive market efficiency, the solution would be to treat coffee as such, with all grades available on both markets with exporters, importers, and local roasters competing freely for any grade of coffee, whether for export or local use.

Value addition or roasted coffee. Value addition in coffee has remained underdeveloped and only about 5 percent of the total production is processed and roasted for export consumption.

The export market barriers to entry and challenges in the local market make for difficult trading conditions. For example, access to proper facilities, if provided by State institutions, is often on the second floor of a factory unit and unsuited for coffee handling and of poor construction standards. Other challenges relate to foreign exchange to import machinery, lack of credit, competing in a highly price-sensitive market that is not overly quality conscious, informal roasters supplying to the market, and unscrupulous baristas willing to take bribes to promote poorer quality coffees. The result is a sector that is limited to small- and medium-scale operations.

Small and micro-level roasters find it challenging to purchase through ECX because the required minimum order is 5 tons. They are restricted to buy through brokers, who are often not interested in smaller quantities. Financing these minimum order size aggravates their already tight liquidity. They also find that the coffee of grade 3 to 5 and below assigned to local markets has a high level of aflatoxin-contaminated and spoiled bean, with up to 20 percent in grade 3 and 50 percent in grade 5 . 
Such coffee requires hand sorting to remove the diseased beans before cleaning, roasting, grinding, and packaging which adds to the cost.

Major domestic customers for roasters are cafeterias and coffee shops. The challenge with these channels is that baristas are open to bribery, so a competitor's coffee, even if of a poorer quality, will be promoted to customers.

Supermarkets, as an alternate channel, are reportedly not preferred due to delayed payments by up to 6-8 months, poor stock-management practices, and inadequate shelf display.

Credit access is another quoted difficulty, especially for working capital requirements and equipment financing. Bank loans typically require collateral that is 2 to 5 times the loan amount, which proves difficult.

Foreign exchange shortages have a negative impact on packaging and equipment purchases. Roasters have to import packaging materials as the local packaging is more expensive and of low quality compared to imported stock. Roasting equipment that can process coffee to the taste requirements of customers is required. Generally, imported equipment is preferred.

FDI: Some local investors have followed a strategy of securing foreign investors, who are able to bring international market access, finance for expansion, and expertise to the business for producing valueadded coffees for exports. The challenge experienced is limitations on shareholding by foreigners to minority stakes and the time it takes to develop a business and break even.

\section{Sector investment and production growth opportunities}

There are several growth opportunities in production, indicating the types of interventions and support required.

- Research into and release of improved commercial coffee varieties: As Ethiopia is a coffee origin and a mother of diversified varieties of coffee, there should be exhaustive research into suitable high-productive, disease-resistant, and climate change resilient varieties that can be grown in different agroecological regions to be released commercially. This would primarily be a government responsibility.

- Application of GAP to increase production: Farmers are currently producing coffee traditionally with minimum application of proper agronomic practices, where they have very old trees with low productivity.

- Coffee tree reestablishment: One of the key practices to boost production of coffee is stumping and pruning. The challenge for smallholders is the income gap because of the 2-to3 -year period of maturation. The ECTA started campaigning and mobilizing farmers to practice stumping but this program needs a properly funded intervention that addresses the income gap to incentivize the transformation.

- Establishment of nurseries with appropriate varieties: Farmers need a source of commercially released varieties. There is a need for a nursery development program at the woreda level. These nurseries need to apply the latest GAP and act as demonstration and training centers. They may also be job creators and provide a business opportunity for unemployed rural youth and women if the right support is provided.

- Traceability and improving WS capacity: Following the new proclamation by the ECTA that exporters can directly export without going through ECX, exporters are now vertically integrating and investing in washing machines and directly purchasing from farmers. Access to land and capital are two elements for exporters to be able to invest in coffee farming and WSs. Many existing WSs use very old equipment that could benefit from recapitalization. Government policy needs to address the land access issue. Ideas on how this may be used as an asset is for farmers not to have to sell the land but that either the sale value gets capitalized into an equity stake in the WS or the WS is rented to provide farm owners with an annuity income stream. 


\section{Challenges and constraints}

\section{i. CREDIT ACCESS}

Shortage of and/or lack of access to finance are significant constraints across the VC. Seasonal finance for timely purchase of cherry and working capital for packaging materials are two factors to be considered. Businesses that do not have finance and liquidity have to wait until later in the season to purchase beans and are forced to buy poorer quality beans at higher prices.

Finance to purchase imported equipment for local processors is another challenge. Because banks only lend to those who have sufficient collateral and they reportedly prefer to deal only with larger clients where foreign exchange is involved, the smaller processor is marginalized.

Thus, there is a need to have a bank credit line that enables access to foreign exchange for importing roasting equipment. Setting up a World Bank and IFC credit line arrangement through the DBE, where local businesses could repay loans in local currency for imported materials, would be a significant advantage.

\section{ii. MARKET INFORMATION}

As there is lack of adequate market information on the coffee roasting business, especially for those wanting to penetrate the export market, market surveys should be conducted. Market information in terms of customers' requirement on styles and taste should be gathered.

\section{iii. MARKET ACCESS}

Access to international value-add markets is a challenge due to the dominant position of large corporates in these specialty markets. These corporates are interested in green coffee beans for value addition in destination markets. The large, established roasters with well-known brands create a trade barrier for small-scale entrants. Tariffs on value-added imports also reportedly play a role in increasing the costs of doing business.

Local roasters have access only to the poorer quality beans unless they export. Additionally, the quality of beans sourced through ECX can be a problem, with up to 20 percent aflatoxins in grade 3 and as high as 50 percent for grade 5 .

The dual trading system between export and local markets creates price differentials and circumvention activities, where the product "leaks" from export to local markets when the price differential is in favor of local sales. Products destined for export are sometimes detained in the hope of a higher price realization but when this does not happen, the product is then "regraded" to poor quality to be sold at a better price locally.

The implications of the details and correct application of the new regulations are not yet known.

Supermarkets in Addis Ababa delay payment for up to 8 months and have a reputation of not handling and displaying the product appropriately.

The fact that baristas are open to bribes is another barrier to trade for ethical businesses.

The current Ethiopian trading system has resulted in a long VC of actors and limited traceability. More customers are demanding traceability and ECX will have to amend its business model to provide traceability and in response to the new regulations.

iv. INFRASTRUCTURE

The feeder road infrastructure is poor, especially in the rainy season. Other infrastructure constraints relate to a restricted electricity grid and connectivity, incomplete rural communication coverage, and water delivery systems for WSs.

\section{Business risks}

International coffee market prices fluctuate because of the variations in supply relative to demand as a consequence of weather changes. These fluctuations are a risk to all businesses in the VC. 
More established exporters focused on coffee are facing increased competition from new entrants who are more concerned about using coffee to raise foreign exchange.

There is a growing level of competition with new, inexperienced entrants in the local roasting sector. The risk of saturation of local demand, according to respondents, is imminent and has resulted in the failure of many new start-up businesses. There is a need to promote consumption of different coffee types and use of better packaging to address the growing local market and also emergence of consumers who are more quality conscious. Local roasters will need to explore offshore markets, having a JV with an international investor, with the brand and ability to penetrate such offshore markets.

Exporters who buy on ECX without the backing of a firm order run the risk of losses should prices drop in the interim while they source orders. These risks could be mitigated by taking a future position on the New York Coffee Exchange (NYCE) or through access to enhanced MIS.

Despite big plans to double or even triple the size of the production base for coffee, the future of the supply base (that is, success of smallholder farmers) is under long-term threat because farmers do not receive a price to sustain interest in production. Reportedly, many neglect their gardens due to this and may switch to other more lucrative cash crops such as Khat. Farmers need to be supported and educated on how to achieve high production of coffee and earn a better income.

The fact that local coffee consumption is increasing with the growth of urbanization and the popularity of traditional coffee 'yegebena buna' coupled with a higher price for the local market may have a modest impact on export volumes if better grades are diverted to the local market.

\section{Business development support}

\section{Logistics and warehousing}

There are several opportunities in logistics and warehousing, indicating the types of interventions and support required.

- Seasonal delivery pressure: During the picking season, there is a significant volume of coffee loaded on trucks coming into ECX warehouses, where they often have to queue and wait for off-loading, which comes at an additional cost for suppliers. A funding program to invest in modernized off-loading and bulk handling is an opportunity to explore with ECX.

- Investment opportunity in ECX warehousing: ECX owns 22 warehouses but it could be argued that its main line of business is a trading platform and not a storage and handling operation. There may be an opportunity for ECX to disinvest from this function and for other private investors specialized in storage and logistics to invest with an appropriately funded structure.

- Multimodel warehouses: After the coffee is sold, the product is transported from an ECX warehouse to the exporter's own processing plant or rented warehouses. Warehouses are busy for 4-5 months and remain idle for the rest of the year. Therefore, exporters find it difficult to invest in their own warehousing and prefer to rent or use service providers that specialize in parchment removal, grading, bagging, labelling, and dispatch. To create an efficient warehousing and logistics system, there may be an investment opportunity in warehousing that offers services to a wider set of commodities in the coffee off-season. 
The case of Horizon PLC

Horizon is a coffee producing and processing company. It has its own farm in Bebeka and Limu.

It processes its own coffee and that of other exporting companies. It has 250 permanent and 1,000 casual laborers. The company is established on $50,000 \mathrm{~m}^{2}$ land where it handles up to 200 trucks per day. It has a warehouse with a capacity of 45 tons and three cleaning machines that remove the coffee husks and clean the green coffee. It offers exporters coffee processing, warehousing, and packaging services. It also has provided space for the CLU, which does the coffee cupping and quality grading, as well as for customs and maritime offices so that exporters can process their export documents under one roof. Although the facility is well organized, the company still faces the challenge of space shortages during the harvesting season, which is 4-5 months (January to May). During this period, the processing capacity is doubled. Yet, after the picking season, the processing machines and warehouse lie idle. Therefore, the company does not want to expand its warehousing business.

\section{Processing or value addition of coffee}

There are several opportunities in processing and value addition of coffee indicating the types of interventions and support required.

- Promotion of roasted coffee internationally: Even though the demand for specialty coffee is increasing in international markets, the export of Ethiopian roasted or value-added coffee has been minimal at 0.1 percent of total exports. Local roasters receive US\$30 to US\$40 per kg for roasted coffee compared to US\$3 per kg at best for green beans. This is due to the high entry barriers in destination markets for roasted coffee, such as tariffs (reportedly 20 percent to 30 percent in the EU), phytosanitary and certification requirements, dominance of major MNCs, lack of access to finance to import packaging materials and modern roasted equipment, inadequate access to processing facilities, and lack of promotion of the sector. Support for promoting the Ethiopian coffee brand could include development of a coffee museum/trade hub with coffee roasting and tasting demonstrations as a focus area, to educate consumers on what good quality and different coffee attributes are, as a platform linking buyers and roasters and as a tourist destination.

- Access to international value added market: The GoE/ECTA should promote access to international markets for locally roasted coffee through trade and food fairs. As Ethiopia is the origin of coffee, higher quality coffee should be roasted, packed, and branded as "single origin specialty Ethiopian coffee."

- Improve the roasting business through better access to foreign exchange: In the short term, local roasters need access to credit and foreign exchange to import roasting equipment capable of making good-quality roasted coffee. Ranking this equipment high on the list of priorities for foreign exchange by the National Bank would be helpful for the local roasters. In addition, ready access to finance would also assist local roasters for timely purchase of seasonal cherry, packaging materials, and imported equipment.

- Develop a local roasting equipment manufacturing business: Local roasters prefer to import equipment from Italy or Germany but there is a local manufacturer. There is an opportunity to support the development of locally manufactured equipment that is able to produce highquality coffee roasts as an alternative to importing equipment.

- Certification to international market standards: Local roasters could benefit from assistance to become certified to the different international market standards, such as ISO and Hazard Analysis and Critical Control Point (HACCP). A program to partially fund (for example, 50 percent) certification costs may incentivize roasters to gain certification and improve their access to a larger market. 
- Market intelligence system: Reliable real-time market intelligence across the whole VC assists markets to function and guides private sector investment decisions. There have been calls for further enhancement of existing MIS, linking the ECX system with the ECTA system and making the information more readily accessible to all VC actors. Such a system would include production statistics, forecasts, yields and volumes being handled and processed through the system, sales, and prices. The development of such a system requires funding and technical support and would require support to train users.

- Access to production facilities: Appropriate factory facilities for roasting within industrial parks, together with a full suite of utility services at competitive rates, could be beneficial to emerging local roasters wishing to export.

- Access to quality beans: Local roasters wanting to develop the specialty coffee market need access to quality beans but are prevented by the current new regulations to buy only through ECX. With the ECTA working on continued improvement in the regulation of coffee marketing, consideration should be given to enabling access to quality beans, even if initially on a quota basis, and also access to smaller order lots than the current minimum order quantity.

\section{Training and capacity building}

The coffee sector is highly constrained by the lack of a formalized training center that can offer different capacity building, knowledge, and skills to conduct business throughout the VC. Currently, the ECTA provides business development services to the sector that includes extension services for farmers, marketing skill, business plan preparation, and promotional activities to exporters through participation in international trade fairs. However, these have been insufficient to satisfy the needs of the sector and make the actors in the chain operate the business efficiently. Thus, there is a need to establish a Coffee Training Institute that can offer training and capacity building on management and operations for WSs, logistics, and warehousing; quality grading of roasted coffee; and general training courses on business management, accounting, business etiquette, and administration-related skills. Furthermore, the training center can assist exporters to comply with international market standards by providing training, coaching, and validation of different certifications for exporters.

\section{Trade and investment support}

About 90 percent of the coffee for local and export markets is traded through ECX. It has created a long VC of actors with different roles as it also has limited membership for exporters and local roasters to buy from traders and brokers at ECX. The ECX trading system has a limitation on traceability compared to the customers' demand. It needs to develop a digitalized market information system that responds to market needs.

\section{Smallholder rehabilitation support}

Farmers need rehabilitation of their coffee trees to improve varieties, boost yields, and increase incomes. This requires an integrated program of support having: local nurseries able to provide improved seed and cuttings, access to the funding for purchasing improved plant material, and a source of income to cover the 2-to-3-year income gap that results from stumping to tree maturity.

The local woreda nurseries could offer opportunities for employment and business ventures for youth and women, but they will need support for establishment. The nursery operators will need capacity development for the application of GAP. Further, they could act as a demonstration and training center of GAP.

\section{Policy and regulatory constraints and possible reforms}

The coffee sector is considered overregulated by private sector respondents, although regulations are updated periodically by the ECTA.

(a) There are restrictions on licensing of local retail outlets for foreign investors or JVs, which may limit the technology and knowledge transfer to local entrepreneurs. 
(b) Traders are allowed to export directly without going via ECX but for local market sales they have to use ECX, where they reportedly sell at up to 40 percent lower than what they could achieve through direct domestic wholesale trade.

(c) Local roasters are only permitted to buy low grade coffee.

(d) There is room for improvement in the communication, enforcement, and implementation of regulations. For instance, WSs should comply with waste management standards. However, the auditing of standards through EOs seem to be unevenly applied with weak enforcement on those who are not complying.

(e) Related companies maintain a dual trading system with traders having both an export and a local trading license, with which they play the market. When the price differential is in favor of local sales, the export product is held back in the hope of a higher price and then regraded to poor quality to be sold at a better price locally.

(f) Many civil servants are suspicious of private actors, resulting in unfriendly services from State institutions. From the interviews conducted, it was learned that it is not possible for foreign entities to engage in the local warehousing and logistics service provision.

From the field observation, it was noted that different government offices

A weekend in custody for a minor VAT infringement has the impact of disincentivizing business growth

The CEO of a coffee export company spent the weekend in custody due to an administrative error on an ETB 11,000 invoice for the sale of a second-hand piece of equipment. This could have been resolved through a phone-call and/or summons to visit the tax office and not through criminalizing the CEO. He now does not want to expand his business further as he may not have the capacity to review every invoice and fears that in case of a small error he will be subject to similar treatment by the tax authorities. mandated for policy, regulation development, and implementation as well as service provision in the coffee sector do not have a platform to discuss common issues for better facilitation of the VC.

\section{Opportunities for meaningful inclusion} of women in business

Women play significant roles across all functions in the VC. However, their meaningful participation is still lagging.

Women at the local roasting level face significant challenges in access to land, facilities, and loans to expand their businesses, develop communication, marketing, and business skills.

\section{Investment in human capital}

The coffee sector is constrained by the lack of an organized training center that offers a range of required skills across the $\mathrm{VC}$.

Currently, the ECTA provides business development services to the sector including extension services for farmers and, to exporters, marketing skills, business plan preparation and promotional activities through participation in international trade fairs. However, these have been insufficient. There is a proposal to establish a Coffee Training Institute offering training in management and operational skills for WSs, logistics, and warehousing; quality grading of roasted coffee; and general training courses on business management, accounting, business etiquette, and administration.

\section{Opportunities for PPPs}

The Coffee Training Institute may offer an opportunity for a PPP with industry. Another possible PPP or privatized service could be that of the CLU. 


\section{Opportunities for investment in research}

As Ethiopia is a coffee origin rich with diversified varieties of coffee, there should be exhaustive research to release high-productive, disease-resistant, and climate change resilient varieties that can be grown in different agroecological regions. In addition, research and development on value addition, new product development, and quality improvements of coffee should be encouraged.

\section{Investment in infrastructure}

Rural infrastructure is of significant value to the private sector, particularly in the areas of

- Rural feeder roads - to connect the farmers to WSs and primary market centers;

- Electricity-supplied at the WS level; and

- Telecommunication-improvements to network coverage in rural areas in support of modern trading and information sharing. 


\subsection{Annex 4: Maize Value Chain Description}

Contribution to the economy - Subsector overview

Maize is an important cereal commodity in Ethiopia, both as a source of food security, accounting for about 20 percent of the total caloric intake, and as a contributor to farmer household income. A challenge for farmers is the price relative to other cereals, being nearly one half that of wheat and teff However, this is offset somewhat by the higher per unit yields of maize compared to these crops.

\section{Production}

Maize accounts for about 30 percent of the total cereal production and is cultivated on about 20 percent of the total area for cereal in Ethiopia. Close to nine million smallholder farmers produced maize in the 2014/15 meher planting season compared to 6.5 million for teff, 4.6 million for wheat, and 4.9 million for sorghum. In the same production year, maize production was 7.2 million tons which is 52 percent higher than teff, 71 percent higher than wheat, and 68 percent higher than sorghum. Moreover, maize production has been increasing rapidly in the past decades and the annual growth rate is 8 percent in most cases. Maize productivity has doubled in Ethiopia over the past decade and yields significantly surpass that of other major regional maize producers such as Kenya, Tanzania, and Uganda.

This improvement has been led by increases in adoption of modern inputs and expanded access to extentsion service. The GoE's focus on agriculture in general and maize, in particular, is a significant contributor to this improvement. Many improved seed varieties, both hybrid and open pollinated types, have been released. However, modern input adoption is still relatively low. There is potential for continued yield increases.

The maize production areas are shown in Figure 10.

Figure 10: Ethiopian Maize Production Areas

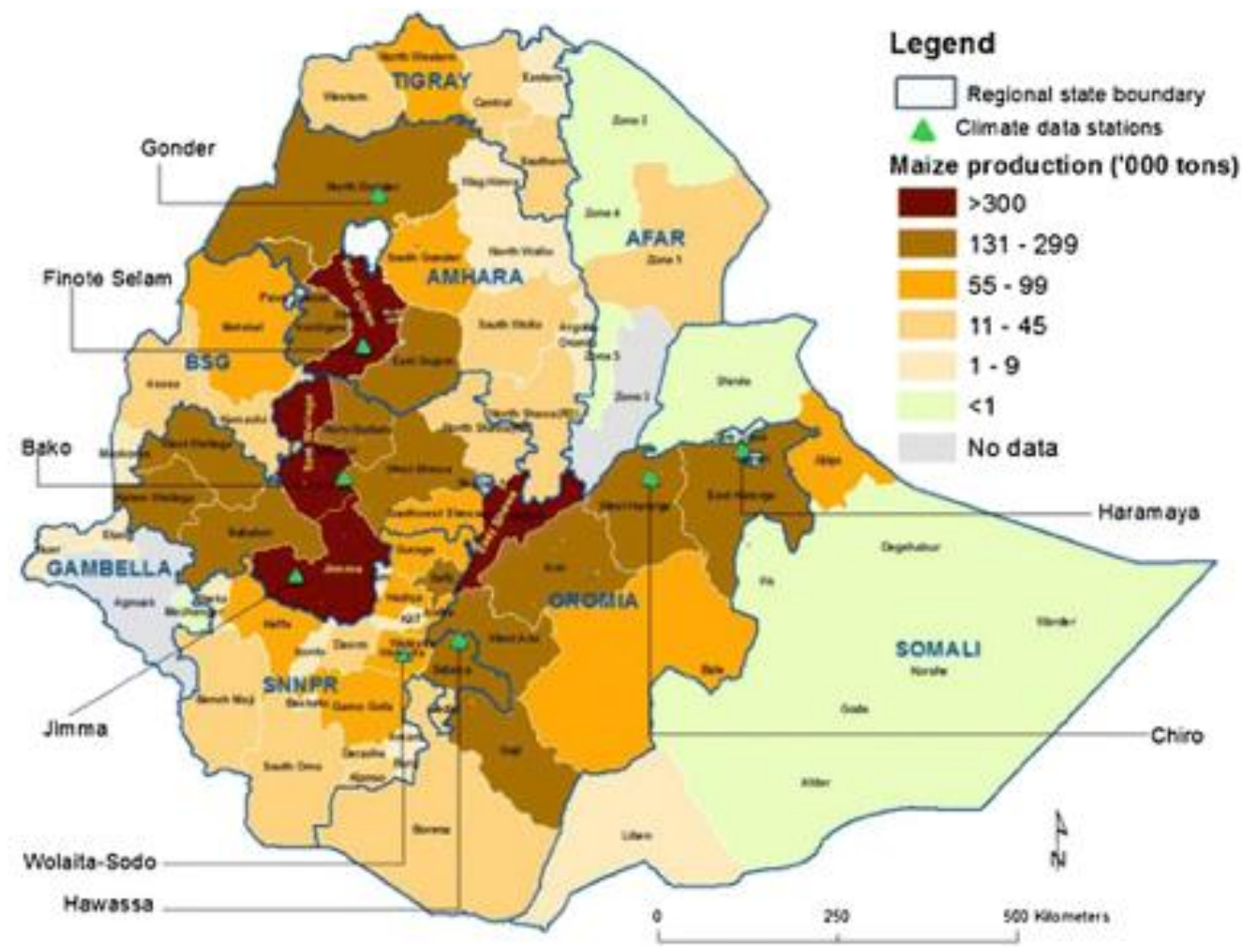

(Source: Abate et al. 2015)

Farming systems 
Over 95 percent of maize production in Ethiopia is by smallholder farmers (on less than 1 hectare) who sell the produce primarily to village traders, cooperatives, and nearby marketplaces. Inputs such as seed, fertilizer, and chemicals are mostly provided through the government and the cooperative system. While fertilizer distribution is fully managed by the government, there is now room for private actors in seed and chemical distribution. The existing supply system is not efficient, as very few private sectors have entered the system. For example, only one popular hybrid maize seed is provided by the private sector.

\section{Marketing of maize}

Trade is dominated by informal traders. Village traders sell maize on local retail markets and to wholesalers through brokers. Wholesalers, in turn sell to retailers, including millers, as well as food and animal feed processors. The millers are usually vertically integrated as both processor and retailer.

Cooperatives and farmer cooperative unions play a small role in marketing maize with most of it going to institutional buyers (that is, millers, food processors, and feed manufacturers).

\section{Maize consumption}

Maize is predominately a subsistence food crop. Approximately 88 percent of maize produced in Ethiopia is consumed as food, both as green and dry grain. For example, farm household consumption accounted for 76 percent of total maize production in 2015/16 and the share of maize that reached the market was only about 11 percent.

Maize is consumed mainly in the form of Eshet tibs/roasted green maize, Eshet kikil/boiled green maize, Nifro/boiled grain, or Bread/injera from maize flour.

This indicates that despite a substantial increase in maize production over the past decade, the marketed surplus through the formal system has not changed much.

The limited use of modern inputs and mechanization by farmers with the low level of commercialization in the trading and processing maize subsector indicates that enhancing the maize VC could give significant returns. Thus, the full adoption of modern maize production technology would increase the marketable surplus as raw material to the feed and food sectors.

On the demand side, maize is an essential crop for food security both at household and country level. Given the current trends in income growth, there is growing demand for processed maize for blended food and as a carbohydrate source for animal feeds. Hence, use of maize for animal feed of beef, dairy, and poultry farms and as raw materials for many industrial products represents potential demand sinks. Moreover, its potential for modern industrial use such as a sweetener, a source of starch, ethanol fuel production, and so on offers a unique opportunity to promote domestic value addition and agro-industry development, which could take place within the industrial parks currently under development. Maize is also used for making local drinks such as tella, tej, and arake. This study helped identify constraints, opportunities, and solutions for leveraging private sector engagement in maize agricultural VCs in Ethiopia using the MFD approach.

\section{Business conduct and private sector opportunities}

Based on the results of this rapid assessment and other VC studies, it is clear that the general maize business will not attract substantive private sector engagement unless more incentive mechanisms are introduced. Current maize marketing is dominated by informal traders who controlled about 90 percent of the maize business. The seed business has room for private sector actors who have the capacity to produce quality seed.

Similarly, there may be opportunities for an integrated agribusiness that provides end-to-end services to farmers. An example is that of the Oromia Agricultural Cooperative Federation. The federation supplies seeds and other inputs needed for maize production, collects and stores harvested maize, and processes it into flour and feed, available for wholesaling and retailing to the consumer. 
The maize business is conducted in three forms based on the purpose: seed businesses, grain/food business, and feed business-all are important in Ethiopia.

The maize seed business has yet to develop as seed supply is reportedly below demand. Very few private seed producers and retailers are operating in the country. The business is mainly dominated by government seed enterprises, both at the national and regional level, who crowd out the opportunities for private actors. For example, the Oromia Cooperative Federation facilitates maize seed multiplication together with Oromia Seed Enterprises, yet many farmers complain of late delivery and prefer to buy the more expensive privately supplied seed such as that from Pioneer Seed.

Grain/food business. The maize and related food and beverage sector have a relatively wide product range, from green maize to flour. The possibiltiies for the private sector lie in the maize grain/food business as opportunities through income and population growth in Ethiopia and surrounding regions. This drives the demand for a variety of food types, where maize and maize product derivatives can be used as ingredients. Many food industries in Ethiopia are reportedly blending 10-20 percent of maize as an ingredient in their products. The same is true for injera and bread preparation. Specializing in food products that use maize as a main ingredient, especially high-protein maize both for children and adults, could be a new business area for the private sector to innovate. For example, HILINA Enriched Food PLC, a food processing company that specializes in the manufacture and processing of food products designed to combat malnutrition and other micronutrient deficiencies, reports that it has started some interesting innovation on high-protein maize products.

Increased demand for maize may also come from food manufacturing businesses that establish enlarged food aid programs and corn-soya blending food factories in the newly emerging industrial parks.

The feed business. There is increased demand for processed feed with the emergence of many modern livestock and poultry farming operations. According to Ethiopia's Livestock Master Plan, there is strong demand for feed products, and investment in livestock agriculture in Ethiopia reportedly has the potential to halve poverty, improve the food security of rural people, and make livestock an increasing contributor to GDP growth. The Ethiopian Livestock Master Plan sets ambitious year 2020 targets for several livestock VCs especially for programs supporting a greater supply of red meat and milk through breeding of crossbred dairy cows, feedlot development, and increased poultry supply. These are designed to meet rapidly growing demands for these agricultural commodities. The 2020 targets aim to increase meat, milk, and egg production by 58 percent, 83 percent, and 828 percent, respectively, above the $2012 / 2013$ totals. These can only be met through secure year-round feed supplies. These increases, as well as the expected rise of the crossbred cattle population to more than 4 million, will require enhanced forage and feed production and feeding services, including improved pasture productivity practices, and training for farmers on livestock feeding and forage production. The rapid assessment of the maize $\mathrm{VC}$ in this regard indicates that maize is the largest feed ingredient used at 30-40 percent of the total ration in most modern feeds processed by Alema Koudjis and EthioChicken feed factories. Maize can also be used as a green fodder through irrigated farming near major rivers.

Table 4: Profile of maize market for small, medium, and large businesses

\begin{tabular}{|l|l|l|l|}
\hline \multicolumn{1}{|c|}{ Issues } & \multicolumn{1}{|c|}{$\begin{array}{c}\text { Micro-business (the } \\
\text { case of retail traders } \\
\text { like Alemitu) }\end{array}$} & $\begin{array}{c}\text { Medium business } \\
\text { (cooperative unions and } \\
\text { wholesale traders) }\end{array}$ & $\begin{array}{c}\text { Large business (Alema } \\
\text { Feed PLC, EthioChicken, } \\
\text { Faffa Food Factory, Coop } \\
\text { Federations) }\end{array}$ \\
\hline Type of business & Small grain shop owner & Medium size business & Big feed factory \\
\hline $\begin{array}{l}\text { Annual turnover } \\
\text { of business }\end{array}$ & <ETB 100,000 & $\begin{array}{l}\text { ETB 1 million to ETB 10 } \\
\text { million }\end{array}$ & >ETB 100 million \\
\hline
\end{tabular}




\begin{tabular}{|l|l|l|l|}
\hline \multicolumn{1}{|c|}{ Issues } & $\begin{array}{c}\text { Micro-business (the } \\
\text { case of retail traders } \\
\text { like Alemitu) }\end{array}$ & $\begin{array}{c}\text { Medium business } \\
\text { (cooperative unions and } \\
\text { wholesale traders) }\end{array}$ & $\begin{array}{c}\text { Large business (Alema } \\
\text { Feed PLC, EthioChicken, } \\
\text { Faffa Food Factory, Coop } \\
\text { Federations) }\end{array}$ \\
\hline Main challenges & $\begin{array}{l}\text { Place of work, storage, } \\
\text { finance, fluctuation of } \\
\text { demand and supply }\end{array}$ & $\begin{array}{l}\text { Finance, modern storage } \\
\text { system, technical capacity }\end{array}$ & $\begin{array}{l}\text { Foreign exchange, raw } \\
\text { materials (soya bean, } \\
\text { maize, and so on), } \\
\text { electricity, and so on }\end{array}$ \\
\hline $\begin{array}{l}\text { Areas of } \\
\text { expansion }\end{array}$ & $\begin{array}{l}\text { To own shop, storage } \\
\text { place, and processing } \\
\text { machine like flour mill }\end{array}$ & $\begin{array}{l}\text { Agro-processing, import- } \\
\text { export business }\end{array}$ & $\begin{array}{l}\text { Wants to export feed that } \\
\text { can cover cost of premix } \\
\text { import }\end{array}$ \\
\hline
\end{tabular}

\section{Institutional Mapping}

\section{Ministry of Agriculture}

The MoA is mandated to develop and refine the overall national agricultural and rural development strategies and policies for the country, with inputs and supports from the regions and other actors working on agricultural development.

Figure 11: Institutional Mapping of State Function Across the Maize VC

\begin{tabular}{|c|c|c|c|c|c|}
\hline Organization & $\begin{array}{l}\text { Research } \& \\
\text { Development }\end{array}$ & Input Supply & Production & Processing & $\begin{array}{l}\text { Distribution \& } \\
\text { Marketing }\end{array}$ \\
\hline EIAR & $\begin{array}{l}\text { - Seed research and } \\
\text { development }\end{array}$ & & & & \\
\hline $\begin{array}{l}\text { Ethiopian Seed Enterprise } \\
\text { and Regional Seed } \\
\text { Enterprise }\end{array}$ & \multicolumn{2}{|c|}{ - Seed multiplication, collection distribution } & & & \\
\hline \multirow[t]{2}{*}{ MoA } & \multicolumn{2}{|c|}{$\begin{array}{l}\text { - Oversee regulation of the seed and other input system - } \\
\text { Certification }\end{array}$} & \begin{tabular}{|l|} 
- Input Desk undertakes \\
estimates and input distribution \\
via coops/unions
\end{tabular} & & \multirow{2}{*}{$\begin{array}{l}\text { - Oversight of export and } \\
\text { import of seed and } \\
\text { regulation of exports in } \\
\text { events of domestic } \\
\text { shortages }\end{array}$} \\
\hline & & - Extension support & $\begin{array}{l}\text { - Promotion of harvest } \\
\text { technologies }\end{array}$ & & \\
\hline RBoA & $\begin{array}{l}\text { - Support technical capacity } \\
\text { building, variety release, } \\
\text { accreditation of seed labs, }\end{array}$ & $\begin{array}{l}\text { - Inspection \& Manage } \\
\text { quality control laboratories }\end{array}$ & & & $\begin{array}{l}\text { - Oversight of Regional } \\
\text { export and import of seed }\end{array}$ \\
\hline \multirow[b]{2}{*}{$\begin{array}{l}\text { Ethiopian Commodity } \\
\text { Exchange }\end{array}$} & & & \multicolumn{2}{|l|}{\begin{tabular}{|l|} 
- MIS on grain trading \\
\end{tabular}} & \\
\hline & & & $\begin{array}{l}\text { - Receives maize at } \\
\text { decentralised collection centres }\end{array}$ & - Storage services & $\begin{array}{l}\text { - Provides a trading and } \\
\text { payment clearance } \\
\text { platform }\end{array}$ \\
\hline EGTE & & & & - Storage & $\begin{array}{l}\text { - Grain trading with the } \\
\text { purpose of stabilizing local } \\
\text { - Export in surplus years }\end{array}$ \\
\hline Federal Cooperative Agency & & - Facilitate input supply & \multicolumn{2}{|c|}{$\begin{array}{l}\text { - Provide technical services to coops (financial, marketing, } \\
\text { pre and post harvest techniques) }\end{array}$} & $\begin{array}{l}\text { - Market information (source } \\
\text { of finance, domestic and } \\
\text { foreign mkt linkage) }\end{array}$ \\
\hline \multirow{2}{*}{ Cooperative unions } & & \multirow{2}{*}{ - Sell inputs } & & $\begin{array}{l}\text { - Processing of maize for } \\
\text { feed and food }\end{array}$ & \multirow{2}{*}{$\begin{array}{l}\text { - Sale and distribution of } \\
\text { processed food and feed }\end{array}$} \\
\hline & & & & - Maize storage & \\
\hline ATA & \multicolumn{4}{|c|}{ - Identify systemic bottlenecks and recommend solutions (Capacity gaps) } & - Market info and linkages \\
\hline
\end{tabular}

\section{Regional Bureaus of Agriculture}

The Regional Bureaus of Agriculture (RBoAs) are mandated for agricultural and rural development in their respective regions. RBoAs develop extension packages and provide support to zonal and woreda offices of agriculture in delivering extension services. They also facilitate alignment across development partners to ensure coordinated agricultural development services are delivered at the woreda level.

\section{Extension Services}

Both research institutions and the MoA depend on extension services to disseminate new technologies and best agronomic practices. The basic unit of extension provision is the Farmer Training Center (FTC), which serves as a training and demonstration site for smallholder farmers in surrounding 
areas, and delivers extension through development agents who provide advisory services to groups of farmers.

\section{Research institutions}

The EIAR and the Regional Agricultural Research Institutes (RARIs) have the mandate to generate, develop, and adapt agricultural technologies that focus on the overall development and needs of smallholder farmers. These institutes play a key role in the development of solutions and technologies toward provision of improved inputs (including improved varieties and mechanization technologies) and recommended agronomic practices. The EIAR is responsible for the coordination of nationwide research trials that test such solutions, and the RARIs are expected to conduct targeted research within various geographies to identify region-specific recommendations.

The EIAR manages a number of federal research centers all mandated to work on a specialized set of agricultural research topics. There are three national maize research centers: Melkasa Research Center for low-land moisture, stress/drought, and heat tolerant varieties; Ambo Research Center for highland maize varieties; and Bako Research Center for mid-altitude and high rainfall varieties.

\section{Ethiopian Seed Enterprise and Regional Seed Enterprises}

Public Seed Enterprises (PSEs) include the Ethiopian Seed Enterprise (ESE) and Regional Seed Enterprises (RSEs). In general, PSEs exercise the double mandate of implementing the government targets to produce sufficient quantities of improved seed for all key crops, including maize, while functioning as an independently profitable business.

\section{Ethiopian Grain Trade Enterprise}

The EGTE was established as the Grain Board in 1949 with the mandate to stabilize prices by encouraging production and protecting consumers from price shocks, maintaining a strategic reserve for disaster and emergency response, and earning foreign exchange through grain exports.

During this time, private sector trading was permissible and traders competed with the EGTE. However, the EGTE faced constant tension in fulfilling its mandate of price stabilization while ensuring competitiveness and profitability (Bekele 2002). Due to limited purchasing power of the grain and sales network, the EGTE was not effective in stabilizing prices. Farmers' confidence in the EGTE declined as it often could not guarantee purchases at the pre-announced prices. As a result, the EGTE diminished its role in price stabilization in the early 2000 s and focused on export promotion.

The Enterprise was reorganized in 1999 for the purpose of purchasing grain, oilseeds, and pulses both for local wholesale and export markets and as such it competes directly with the private sector. The EGTE also supplies food grain for government, NGOs, city dwellers, and industrial customers.

Ancillary services include warehousing and store management, with an 820,000-ton capacity, transportation, weighbridge, on-request market information, fumigation service, and issuance of quality certificates.

\section{Federal Cooperative Agency}

The Federal Cooperative Agency is mandated to lead the Ethiopian cooperative movement both through its structure from region to woreda and educating of functional cooperatives at different levels. Agricultural cooperatives have an important role to play in organizing smallholder farmers and providing inputs and output marketing services. Currently, there are about 10,000 primary agricultural cooperatives, 160 unions, and 3 federations in Ethiopia. Thus, a large proportion of maize is marketed by cooperatives.

\section{Agricultural Transformation Agency of Ethiopia}

As articulated in the Ethiopian Council of Ministers Regulations No. 198/2010 and 380/2016, the ATA is mandated to execute the following four distinct strategic goals: 
- To identify systemic constraints of agricultural development, through conducting studies, recommend solutions, and ensure sustainability and structural transformation

- To support implementation of recommended solutions

- To support the establishment of strong links among agricultural, related institutions, and projects, to ensure the effectiveness of agricultural development activities

- To manage and lead the implementation of specific solutions as projects

Accordingly, maize is identified as one among strategic commodities that the ATA is working on starting from its VC development.

\section{Other relevant ministries}

The Ministry of Trade has a mandate to strengthen Ethiopia's agricultural export sector and improve the country's competitiveness in foreign markets, by formulating and implementing export promotion policies and strategies and collecting, analyzing, and disseminating export trade related information to relevant members of the business community.

The Ministry of Industry has a mandate to develop agro-processing industries. This is done by creating conducive conditions to encourage investment in the sector, generating agro-processing industrial project ideas and linking relevant stakeholders, attracting joint ventures from abroad, and providing support to agro-processors, in line with the country's industrial development strategy.

Both these ministries are now consolidated as the Ministry of Trade and Industry.

\section{Ethiopian Commodity Exchange}

Maize marketing was the first commodity that triggered the establishment of ECX based on the study of mesalemia Ehil berenda (the biggest grain market in Addis Ababa). There is an ongoing effort to improve the marketing system of maize through ECX, which plays exchange, warehousing, and finance clearing roles. By recognizing the diverse actors involved in commercial grain maize marketing (producer smallholders and commercial farms, wholesalers, retailers, part-time farmer-traders, brokers, agents, assemblers, processors, cooperatives, the EGTE, and consumers), ECX has been promoting a timely market information system for maize.

An ECX market information system also includes collecting, processing, and making available real-time market information. The key market dissemination channels at ECX are rural-based market information tickers; mobile phone short messaging service (SMS); interactive voice response (IVR) service; mass media (TV, radio, and newspaper); and website (www.ecx.com.et). Market information includes prices of commodities in different markets and commodity offers to bid or buy, as well as short extension messages. Three categories of maize were recognized by ECX with 5 grades for each: white maize (WM), yellow maize (YM), and mixed maize (MY). The grades are determined based on test mass, proportion of impurities, and contrasting color of grains.

However, maize is not being traded on the ECX platform as it was planned initially, and ECX has recently shifted its focus to coffee, sesame, and pulses. Thus, given its experience in commodity trading so far, ECX has a potential role to play in establishing the maize marketing information system with other relevant institutions.

\section{Challenges and constraints}

Doing business in the maize sector has its own challenges and constraints. Challenges hindering the full development of the sector include supply of quality and quantity seeds, sources of financing to expand the business, weak regulation, weak supply of production and harvesting technologies, inadequate technical capacity for research, and weak cooperative operations.

Lack of infrastructures such as roads, poor storage system, domination of informal trade, and weak market information systems are factors constraining the development of the maize VC. Competition 
between formal and informal traders and between formal traders and cooperative unions is another challenge.

\section{Business risks}

Risks in the maize sector start with variable climate and the concerns about impacts of climate change, which point to inadequate rainfall in the future, pests such as the Fall Army Worm and the damage this creates, and spoiling due to aflatoxin from poor quality harvest and storage systems.

Lack of risk mitigation mechanisms such as crop insurance to reduce unforeseen catastrophic risks such as weather are other factors to consider. Government could consider the development of risk mitigation mechanisms such as micro-insurance/index-based insurances for weather-related risks, investment in applied research on crop protection strategies and controls, and investment in facilitating the development of modern storage facilities, whether they be private and/or government.

\section{Business development support}

Private sector engagement is determined by many factors such as return on investment; capacity limits; limited supply; and relatively low, albeit improving, demand, for maize-related food products compared to other products such as coffee, teff, wheat, and pulses.

The introduction of financing mechanisms that support innovation, promotion, and marketing of maize products will help expand the investment opportunities.

Examples of incentive mechanisms that could be considered are continued exemption of taxation duties on imported machinery for maize production and processing, availability of low-cost land for factory development, and reliable access to credit for investors who are prepared to venture into commercial maize farming in the remotest part of the country and need to develop significant capital infrastructure such as irrigation and roads.

Advisory support is required to guide investment and the MoA's current study on re-identification of potential areas for investment in agriculture by private actors as contribution to achieving GTP II objectives will be a useful guide for decision making.

\section{Trade and investment support}

Feed processors (Alema and EthioChicken) express the difficulty in accessing foreign exchange necessary to import additives. These additives make up a small 2 percent proportion of animal feed. Without this, the remaining 98 percent of locally procured ingredients making up the feed will not provide the required nutritional value, with a consequent negative knock-on effect on sales.

In the past, feed manufacturers have been affected by maize export bans. They would benefit greatly if a concession was made to guarantee the right to export a level of feed that would finance their foreign exchange requirements to import additives.

On the other side, a permit license to open other processing wings can offer private actors the opportunity to make their own input/raw material. For example, EthioChicken wants to open a plant for processing soya bean oil, its byproduct will be raw material for the feed factory. EthioChicken is losing about 40 percent of its margin as the company has contracted another organization with a license for soya bean oil processing.

\section{Access to finance and risk management}

Smallholder farmers, small and medium enterprises (SMEs), have limited access to credit because they lack assets which can be used as collateral. The same is true for micro-traders.

Lack of access to basic financial services and credit hinders activity and participation across the VC and imposes working capital constraints. For example, farmers are forced to sell quickly at low prices during harvest and borrow at a higher interest rate from informal financial sources during the cropping 
session. The consequence is a reduction in available personal savings with which to finance longerterm investment and growth.

Poor access to finance is illustrated by the fact that agriculture receives only 10 percent share of credit provided, yet contributes 44 percent to GDP and accounts for 85 percent of employment. Similarly, a lack of access to insurance increases farmers' exposure to climate and market risk and affects the ability to comply with contractual supply agreements. Moreover, low financial knowledge and management capacity exacerbates traders' lack of access to financial services, reducing rural and agricultural opportunities.

The government should consider supporting the development of modalities through which different instruments, such as warehouse receipts, insurance policies, and other methods, can be used as a guarantee by smallholder farmers and SMEs to get credit. This should also be accompanied by financial literacy training.

There is a reported initiative to link cropspecific financing with Land Investment for Transformation (LIFT) so that SLLCS can be used as collateral for individual loans of higher value for the farmers who require it.

\section{Policy and regulatory constraints and possible reforms}

The policy and regulations in relation to maize marketing lacks consistency in application. For example, any export ban and importation of maize has a significant impact on the local market and the manufacturing sector. Though the aim of an export ban on some cereal crops is to protect the public from unwanted price hikes, extended export bans affect the processing sector by reducing market options in the broader region and create a disincentive for producers to plant, leading to further restrictions on availability of supply to the manufacturing sectors.

Similarly, lifting the export ban without sufficient forewarning and at the appropriate time to align with the production season decisions again negatively affects the local market as there can be a sudden price increase for local consumers and processors. The lifting of the export ban in 2017 doubled the price of maize, when the price increased from around ETB 400 to ETB 900 per quintal (1 quintal $=100 \mathrm{~kg}$ ) and has not come down since then. This has negatively affected companies' cash

Market days for Alemitu (grain rental shop owner in Adama) Alemitu runs a small grain retail shop in Amede Gebeya in Adama City of Oromia region. She rents the shop, which was originally allotted to somebody else by the municipality. She sells almost all major grains such as teff, maize, wheat, and sorghum and pulses such as beans and chickpea. She gets most of the grains from wholesalers in Adama Nur Piassa or directly from farmers who transport them on donkeys during the harvesting season. Similar to the trends in other places, Alemitu adds a margin of ETB 1 per $\mathrm{kg}$ on the purchase price of grain during sale. The main concerns for Alemitu and traders like her are rent for the shop or the owner's demands, source of finance to expand her business, and storage facilities. She keeps extra grain outside the shop during the dry season. Her biggest challenge is the rainy season as the shop has poor storage facilities both in terms of quality and the quantity of grain that can be stored. She says that she can improve her business if the government facilitates proper storage facilities for the shop and financing to expand the business.

Volume of transaction: 50-100 quintals of grain based on the supply and demand.

Annual turnover: ETB 50,000-100,000 based on the market demand/supply situation.

Unintended consequences of export bans

For example: Tanzania (2011) - Maize export ban intended to protect consumers against rising prices and maintain food security lowered production producer incomes resulted in - Reduced production of maize by $\sim 0.5 \%$ to $2 \%$ in the short term and $\sim 3 \%$ to $8 \%$ in the medium to long term (6 years); and - Reduced agricultural GDP across producing regions due to reduced income incentive to produce maize. flow forecasts. 
There are several policies and regulatory constraints throughout the maize VC with possible reforms for consideration set out in Table 5.

Table 5: Constraints identified in the maize VC and policy reform opportunities

\begin{tabular}{|c|c|}
\hline Constraints & Policy reform opportunities for consideration \\
\hline $\begin{array}{l}\text { - Absence of independent seed regulatory } \\
\text { body } \\
\text { - Lack of hard currency to import mother } \\
\text { seeds } \\
\text { - Limitation of role played by research }\end{array}$ & $\begin{array}{l}\text { - Establish independent and professional seed } \\
\text { regulatory body } \\
\text { - Support on hard currency needed } \\
\text { - } \quad \text { Give full responsibility to seed dealers }\end{array}$ \\
\hline $\begin{array}{l}\text { - Weak infrastructure such as roads, } \\
\text { electricity, and maintenance services } \\
\text { - } \quad \text { Land tenure system } \\
\text { - Lack of contract farming law }\end{array}$ & $\begin{array}{l}\text { - Investment in infrastructure development } \\
\text { - Improvement of land tenure system and } \\
\text { development of contract farming law } \\
\text { - Scaling-up of the SLLC }\end{array}$ \\
\hline $\begin{array}{l}\text { - Few harvesting technologies for seed } \\
\text { enterprises and capacity gap } \\
\text { - Loss during harvesting }\end{array}$ & $\begin{array}{l}\text { - Support to private actors that work on maize } \\
\text { harvesting technologies such as combiner and } \\
\text { shellers } \\
\text { - Develop incentives for technology producers }\end{array}$ \\
\hline $\begin{array}{l}\text { - Weak grading and standardization of maize } \\
\text { for different purposes }\end{array}$ & $\begin{array}{l}\text { - Promotion of maize grading and standardization } \\
\text { that can be used as ingredient for different } \\
\text { processors }\end{array}$ \\
\hline $\begin{array}{l}\text { - } \quad \text { Low quality of limited storage facilities } \\
\text { - Absence of separate storage for maize } \\
\text { - Aflatoxin risk }\end{array}$ & $\begin{array}{l}\text { - Promotion of privately-owned modern storage } \\
\text { system } \\
\text { - Incentives such as free land for private actors that } \\
\text { plan to invest in modern warehouse services }\end{array}$ \\
\hline $\begin{array}{l}\text { - } \quad \text { Effect of export ban and lifting the ban } \\
\text { - Lack of incentives (access to hard currency } \\
\text { and tax exemption) }\end{array}$ & $\begin{array}{l}\text { - Introduce incentive mechanisms, such as access to } \\
\text { hard currency and tax exemption }\end{array}$ \\
\hline $\begin{array}{l}\text { - Low demand owing to undeveloped culture } \\
\text { of maize consumption as a food } \\
\text { - } \quad \text { Absence of recognition for maize portion } \\
\text { used in many food items (bread, injera) } \\
\text { - Competition from imported baby foods } \\
\text { - Food nutrition issues }\end{array}$ & $\begin{array}{l}\text { - Develop regulations that allow maize use in certain } \\
\text { food items (bread, injera, beer, sugar) and oil } \\
\text { factories } \\
\text { - } \quad \text { Promotion of import substitution and local food } \\
\text { processing for maize, such as maize-soya blended } \\
\text { baby foods, snacks, and cornflakes } \\
\text { - Promotion of high-protein maize varieties }\end{array}$ \\
\hline $\begin{array}{l}\text { - Lack of incentives such as free land and tax } \\
\text { deduction }\end{array}$ & $\begin{array}{l}\text { - Introduction of incentives for free land and tax } \\
\text { reduction }\end{array}$ \\
\hline $\begin{array}{l}\text { - Lack of formal contract, absence of credit, } \\
\text { unreliable supply } \\
\text { - } \quad \text { High transportation costs } \\
\text { - Inconsistent and unreliable market with ECX, } \\
\text { World Food Programme (WFP), and EGTE }\end{array}$ & $\begin{array}{l}\text { - Investment in infrastructure, such as storage, roads, } \\
\text { and logistics, including through a PPP approach }\end{array}$ \\
\hline - Tax increase & $\begin{array}{l}\text { - Introduce tax incentive mechanism that promotes } \\
\text { formal businesses }\end{array}$ \\
\hline
\end{tabular}


